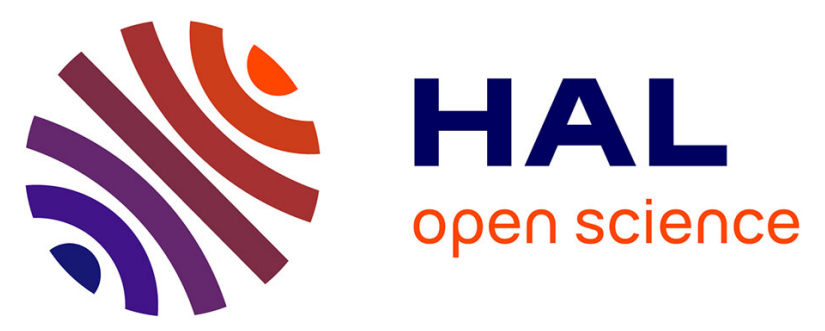

\title{
Impact of the functionalized tetrazole ring on the electrochemical behavior and biological activities of novel nickel (II) complexes with a series of tetrazole derivatives
}

\author{
Y. Allab, S. Chikhi, S. Zaater, M. Brahimi, S. Djebbar
}

\section{To cite this version:}

Y. Allab, S. Chikhi, S. Zaater, M. Brahimi, S. Djebbar. Impact of the functionalized tetrazole ring on the electrochemical behavior and biological activities of novel nickel (II) complexes with a series of tetrazole derivatives. Inorganica Chimica Acta, 2020, 504, pp.119436. 10.1016/j.ica.2020.119436 . hal-02472934

\section{HAL Id: hal-02472934 \\ https://hal-univ-rennes1.archives-ouvertes.fr/hal-02472934}

Submitted on 17 Feb 2020

HAL is a multi-disciplinary open access archive for the deposit and dissemination of scientific research documents, whether they are published or not. The documents may come from teaching and research institutions in France or abroad, or from public or private research centers.
L'archive ouverte pluridisciplinaire HAL, est destinée au dépôt et à la diffusion de documents scientifiques de niveau recherche, publiés ou non, émanant des établissements d'enseignement et de recherche français ou étrangers, des laboratoires publics ou privés. 


\title{
Impact of the functionalized tetrazole ring on the electrochemical behavior and biological activities of novel nickel (II) complexes with a series of tetrazole derivatives
}

\begin{abstract}
Yacine Allab $^{\text {a*}}$, Sabah Chikhi ${ }^{\mathrm{a}, \mathrm{b}}$, Sihem Zaater ${ }^{\mathrm{c}}$, Meziane Brahimic and Safia Djebbar ${ }^{\mathrm{a}}$
aLaboratoire d'Hydrométallurgie et Chimie Inorganique Moléculaire, Faculty of Chemistry, Houari Boumediene Sciences and Technology University, BP 32, El Alia, Bab Ezzouar, Alger, Algeria.

'UMR 6226 CNRS-Université de Rennes 1 "Organométallique, Matériaux et Catalyse", Campus de Beaulieu, 35042 Rennes, France.

'Laboratoire de Physico-Chimie Théorique et de Chimie Informatique, Faculty of Chemistry, Houari Boumediene Sciences and Technology University, BP 32 El Alia, 16111 Algiers, Algeria.
\end{abstract}

\begin{abstract}
Six new nickel (II) complexes with a series of tetrazole derivatives functionalized by different substituents \{5-(2-(1-Benzyltetrazol-5-yl) phenyl)-2-ethyl-4-methylthiazole (L $\left.{ }^{1}\right), 1$-Benzyl-5-(2-(1methylpyrrol-2-yl)phenyl) tetrazole $\quad\left(\mathrm{L}^{2}\right), \quad$ 5-(2-(1-Pivalyltetrazol-5-yl)phenyl)-2-ethyl-4methylthiazole $\left(\mathrm{L}^{3}\right)$, 5-(2-(1-Methylpyrrol-2-yl) phenyl)-1-pivalyltetrazole $\left(\mathrm{L}^{4}\right)$, 2-Ethyl-4-methyl5-(2-(1 methyltetrazol-5-yl) phenyl) thiazole ( $\left.\mathrm{L}^{5}\right)$ and 1-Methyl-5-(2-(1-methylpyrrol-2-yl)phenyl) tetrazole $\left.\left(\mathrm{L}^{6}\right)\right\}$ have been synthesized and characterized by analytical and spectral methods. The data clearly indicated that the nickel (II) complexes are coordinated to the monodentate tetrazole derivatives via nitrogen (N3) atom of the tetrazole ring. The octahedral geometry is observed for all the complexes. The thermogravimetric analysis revealed the presence of coordinated and hydrated water molecules in the coordination sphere. The DFT calculations performed on both the ligands and the complexes allowed to optimize the structures, the stability and to explain the electrochemical behavior and the biological activities of the nickel (II) complexes.

The study of the substituents effects on the redox properties of the ligands and their nickel (II) complexes were discussed via cyclic voltammograms. Electron donating substituents shift the reduction potentials toward negative values, while anodic shift of the oxidation potentials is manifested by the substituents having an electron withdrawing effect.

The in vitro antimicrobial activities of the ligands and their corresponding nickel (II) complexes have been evaluated against four bacterial and two fungal strains.

*Corresponding author. Laboratoire d'Hydrométallurgie et Chimie Inorganique Moléculaire, Faculty of Chemistry, Houari Boumediene Technologies Sciences University (U.S.T.H.B), BP32 El Alia Algiers, Algeria.

E-mail address: yacinecm34@,gmail.com
\end{abstract}


$\mathrm{L}^{1}-\mathrm{L}^{6}$ ligands and their nickel (II) complexes showed a better activity against Gram-positive bacteria. The reactivity of the complexes against Streptococcus group D varied from very sensitive to extremely sensitive activity. No activity has been recorded for the six ligands against the tested fungal strains but their complexes showed extremely sensitive antifungal activity against these strains. The electron donating effect of the substituents was found to weaken the antimicrobial activity of the complexes.

The antioxidant activity of the compounds has been evaluated using the DPPH method. The results indicated that the ligands and their nickel (II) complexes exhibited a better activity against the radical DPPH in comparison to the used reference. Electron withdrawing effect of the substituents on the ligands enhanced the antioxidant activity of the ligands and their complexes.

Keywords: Nickel (II) complex, Tetrazole derivatives, DFT, TGA, cyclic voltammetry, biological activity.

\section{INTRODUCTION}

Microbial infection is one of the major threats in the world. For this reason, researches in medicinal chemistry have been interested in the development of many antimicrobial agents and widely used to treat them. But from the beginning of the development, the resistance of microorganisms to antimicrobial agents was recognized. In this regard, there is always a need for the identification of novel chemical compounds with antimicrobial activities [1-6].

Tetrazole derivatives form an important class of compounds that possess interesting pharmacological and biological properties [7]. Many studies dealing with the synthesis of new tetrazole derivatives having biological activities are published [8-14]. These compounds possess antimicrobial, anticancer and other biological activities. It is not a coincidence that these compounds are incorporated in a large number of drugs approved by food and Drug Administration (FDA) and World Health Organisation (WHO) [15]. Tetrazole rings are considered as an important descriptor in the methodology of the design of new drugs using the analogue based drug discovery (ABDD) method [16].

The chemistry of transition metal complexes containing nitrogen, oxygen and other donors has attracted a great attention [17-20]. This is due to the fact that the biological properties of the coordinated ligands increase upon complexation with metal ions [21, 22].

For many years, nickel was not considered to play an important biological role. This fact has completely changed with the discovery of the presence of nickel in the active center of the enzyme urease [23]. Since then, the determination of nickel-containing or dependent enzymes was the main 
factor of the biological expanded of nickel [24]. Furthermore, a lot of nickel complexes acting as antimicrobial [25-27] and anti-inflammatory [28] activity was also found in the literature.

In this context, we report the effect of the functionalized tetrazole ring on the electrochemical behavior and biological activities of new nickel (II) complexes. These complexes are formed at solid state with a series of tetrazole derivatives $L^{1}-L^{6}$ previously synthesized by our group [29] and containing different substituents (scheme1). Analytical and spectral methods were used to characterize the complexes. Density functional theory (DFT) calculations were carried out to optimize the geometry of the nickel complexes. The theoretical results have then been correlated with the experimental data in order to confirm the coordination mode of the ligands to the metal ion. The electrochemical properties of the ligands and their nickel (II) complexes were investigated by the cyclic voltammetry. These compounds were then subjected to in vitro antibacterial activity against two Gram-negative (Echerichia Coli, Klebsiella pneumoniae) and two Gram-positive (Staphylococcus aureus, Streptocoque D) bacterial strains and for in vitro antifungal activity against (Candida albicans and Trichophyton rubrum)fungal strains. The antioxidant activity of the entire compounds using the DPPH method has also studied.
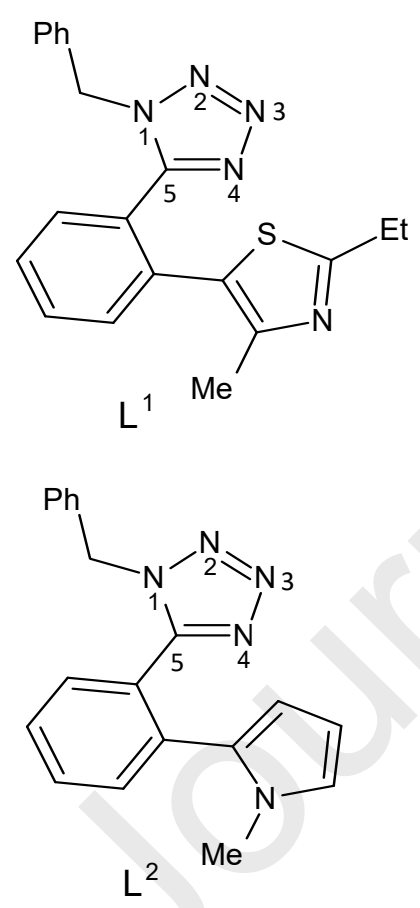

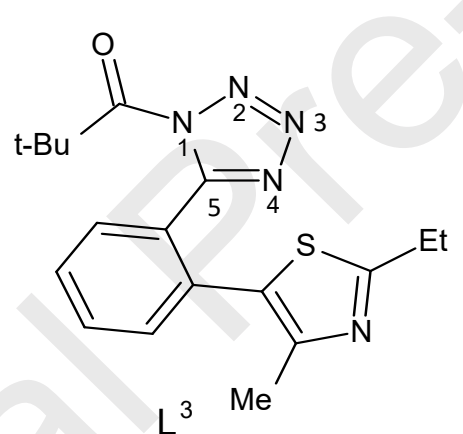

$\mathrm{L}^{3}$

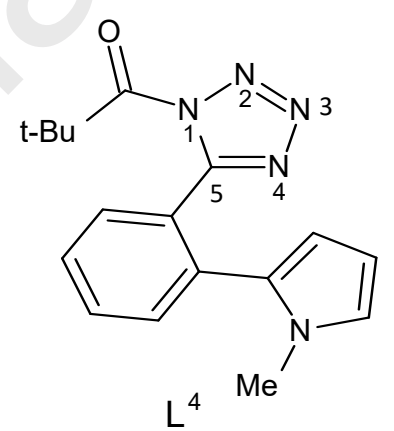

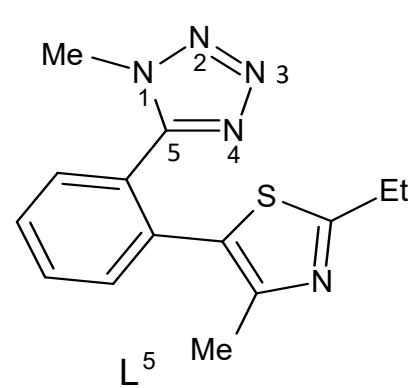

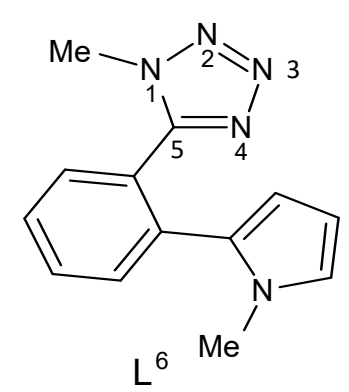

Scheme 1. Structure of the different ligands.

The electronic effects of (Benzyl, Pivaloyl and Methyl) substituents located in position 1 and ([2-(2ethyl-4-methylthiazol) phenyl], [2-(1-methyl pyrrol-2-yl) phenyl]) substituents located in position 5 of the ligands (scheme 1) on the electrochemical behavior and the biological activities of the ligands and their nickel (II) complexes have been discussed. 


\section{Experimental}

\subsection{Reagents}

All reagents used were analytical grade, solvent (Merck) such as ethanol and Dimethyl Sulfoxide (DMSO) were used without farther purification; $\mathrm{NiCl}_{2} \cdot 6 \mathrm{H}_{2} \mathrm{O}(\mathrm{FluKa})$.

\subsection{Synthesis of ligands}

2.2.1. synthesis of $\mathrm{L}^{1}$ and $\mathrm{L}^{2}$ ligands

5-(2-(1-Benzyltetrazol-5-yl)phenyl)-2-ethyl-4-methylthiazole( $\mathrm{L}^{1}:$ Scheme1) and 1-Benzyl-5-(2-(1methylpyrrol-2-yl)phenyl) tetrazole ( $\mathrm{L}^{2}$ : Scheme1) were synthesized following the general procedure [29], using a mixture of 1-benzyl-5-(2-bromophenyl)tetrazole (0.5mmol), Potassium pivalate (PivoK) (1mmol), 0.1mmol $\mathrm{PdCl}\left(\mathrm{C}_{3} \mathrm{H}_{5}\right)$ (dppb) in $2 \mathrm{ml}$ of DMA and 2-ethyl-4methylthiazole $(0.75 \mathrm{mmol})$ for $\mathrm{L}^{1}$ ligand and $2 \mathrm{mmol}$ of $\mathrm{N}$-methylpyrrole for $\mathrm{L}^{2}$ ligand. The reactions were performed at $150^{\circ} \mathrm{C}$ under argon atmosphere, the coupling product obtained after evaporation of the solvent and purification on silica gel (Pentane- $\mathrm{Et}_{2} \mathrm{O} / 70: 30$ ).

\subsection{2. synthesis of $\mathrm{L}^{3}$ and $\mathrm{L}^{4}$ ligands}

5-(2-(1-Pivalyltetrazol-5-yl)phenyl)-2-ethyl-4-methylthiazole(L $\mathrm{L}^{3}: \quad$ Scheme1) and 5-(2(1Methylpyrrol-2-yl)phenyl)-1-pivalyltetrazole (L ${ }^{4}$ : Scheme1) were prepared following the general procedure [29], using a mixture of $0.5 \mathrm{mmol}$ of 5-(2-bromophenyl)-1-pivalyltetrazole, $1 \mathrm{mmol}$ of PivoK, $0.1 \mathrm{mmol}$ of $\mathrm{PdCl}\left(\mathrm{C}_{3} \mathrm{H}_{5}\right)$ (dppb) in $2 \mathrm{ml}$ of DMA and $0.75 \mathrm{mmol}$ of 2-ethyl-4-methylthiazole for $\mathrm{L}^{3}$ ligand and $2 \mathrm{mmol}$ of $\mathrm{N}$-methylpyrrole for $\mathrm{L}^{4}$ ligand. The reactions were performed at $150^{\circ} \mathrm{C}$ under argon atmosphere, the coupling product obtained after evaporation of the solvent and purification on silica gel (Pentane- $\left.\mathrm{Et}_{2} \mathrm{O} / 70: 30\right)$.

\subsection{3. synthesis of $\mathrm{L}^{5}$ and $\mathrm{L}^{6}$ ligands}

2-Ethyl-4-methyl-5-(2-(1-methyltetrazol-5-yl)phenyl) thiazole (L 5 : Scheme1) and 1-Methyl-5-(2(1-methylpyrrol-2-yl)phenyl)tetrazole $\left(\mathrm{L}^{6}:\right.$ Scheme1) were prepared following the general procedure [29], using a mixture of $0.5 \mathrm{mmol}$ of 5-(2-bromophenyl)-1-methyltetrazole, $1 \mathrm{mmol}$ of PivoK, $0.1 \mathrm{mmol}$ of $\mathrm{PdCl}\left(\mathrm{C}_{3} \mathrm{H}_{5}\right)$ (dppb) in $2 \mathrm{ml}$ of DMA and $0.75 \mathrm{mmol}$ of 2-ethyl-4-methylthiazole for $\mathrm{L}^{5}$ ligand and $2 \mathrm{mmol}$ of $\mathrm{N}$-methylpyrrole for $\mathrm{L}^{6}$ ligand. The reactions were performed at $150^{\circ} \mathrm{C}$ under argon atmosphere, the coupling product obtained after evaporation of the solvent and purification on silica gel (Pentane- $\left.\mathrm{Et}_{2} \mathrm{O} / 70: 30\right)$. 


\subsection{Synthesis of complexes}

Nickel complexes were prepared by adding drop wise an ethanolic solution (1 mmol) of $\mathrm{Ni} \mathrm{Cl}_{2}$. $6 \mathrm{H}_{2} \mathrm{O}$ to a solution of ligands $(2 \mathrm{mmol})$ dissolved in the same solvent in 1:2metal to ligand molar ratio. The mixture turned immediately to green was heated under reflux over $5 \mathrm{~h}$. The obtained precipitated complexes were then filtered off, washed with distiller water and ethanol, dried at $50^{\circ} \mathrm{C}$ and finally stored in flasks.

2.3.1. [ $\left.\mathrm{Ni} \mathrm{L}_{2}{ }_{2} \mathrm{Cl}_{2}\left(\mathrm{H}_{2} \mathrm{O}\right)_{2}\right] .2 \mathrm{H}_{2} \mathrm{O}$ : calculated: C, 51.96; H, 4.14; N, 15.15; S, 6.94; Cl, 7.67; Ni, $6.35 \%$; found: C, 51.5; H, 4.4; N, 15.7; S, 6.1; Cl, 7.1; Ni, 7.1\%.

2.3.2. [ $\mathrm{Ni} \mathrm{L}^{2}{ }_{2} \mathrm{Cl}_{2}\left(\mathrm{H}_{2} \mathrm{O}\right)_{2}$ ] $2 \mathrm{H}_{2} \mathrm{O}$ : calculated: $\mathrm{C}, 54.83 ; \mathrm{H}, 4.12 ; \mathrm{N}, 16.83 ; \mathrm{Cl}, 6.11 ; \mathrm{Ni}, 7.05 \%$; found: $\mathrm{C}, 55.1 ; \mathrm{H}, 4.8 ; \mathrm{N}, 16.7 ; \mathrm{Cl}, 5.9 ; \mathrm{Ni}, 7.1 \%$.

2.3.3. [Ni $\mathrm{L}_{2}{ }_{2} \mathrm{Cl}_{2}\left(\mathrm{H}_{2} \mathrm{O}\right)_{2}$ ] $.2 \mathrm{H}_{2} \mathrm{O}$ : calculated: $\mathrm{C}$, 47.38; H, 4.64; N, 15.33; $\mathrm{S}, 7.03 ; \mathrm{Cl}$, 7.77; Ni, $6.43 \%$; found: $\mathrm{C}, 46.1 ; \mathrm{H}, 4.6 ; \mathrm{N}, 16.1 ; \mathrm{S}, 6.9 ; \mathrm{Cl}, 7.2 ; \mathrm{Ni}, 6.8 \%$.

2.3.4. [ $\mathrm{Ni} \mathrm{L}^{4}{ }_{2} \mathrm{Cl}_{2}\left(\mathrm{H}_{2} \mathrm{O}\right)_{2}$ ] $2 \mathrm{H}_{2} \mathrm{O}$ : calculated: $\mathrm{C}, 49.78 ; \mathrm{H}, 4.69 ; \mathrm{N}, 17.07 ; \mathrm{Cl}, 8.64 ; \mathrm{Ni}, 7.90 \%$; found: $\mathrm{C}, 49.1 ; \mathrm{H}, 4.4 ; \mathrm{N}, 17.3 ; \mathrm{Cl}, 8.1 ; \mathrm{Ni}, 6.9 \%$.

2.3.5. [ $\mathrm{Ni} \mathrm{L}^{5}{ }_{2} \mathrm{Cl}_{2}\left(\mathrm{H}_{2} \mathrm{O}\right)_{2}$ ] $.2 \mathrm{H}_{2} \mathrm{O}$ : calculated: $\mathrm{C}$, 43.54; H, 3.91; N, 18.13; S, 8.39; Cl, 9.18; Ni, 7.60\%; found: C, 44.0; H, 3.8; N, 18.1; S, 9.1; Cl, 9.3; Ni, 6.9\%.

2.3.6. $\left[\mathrm{Ni} \mathrm{L}^{6}{ }_{2} \mathrm{Cl}_{2}\left(\mathrm{H}_{2} \mathrm{O}\right)_{2}\right.$ ] $2 \mathrm{H}_{2} \mathrm{O}$ : calculated: $\mathrm{C}, 45.91 ; \mathrm{H}, 3.85 ; \mathrm{N}, 20.6 ; \mathrm{Cl}, 10.42 ; \mathrm{Ni}, 8.63 \%$; found: $\mathrm{C}, 46.1 ; \mathrm{H}, 3.7 ; \mathrm{N}, 20.1 ; \mathrm{Cl}, 9.8 ; \mathrm{Ni}, 8.1 \%$.

\subsection{Analytical and Physical measurements}

The elemental microanalysis was carried out using a Perkin-Elmer Analyser 2400. Melting points were measured using a digital melting points apparatus SMP3 using capillary technique. The molar conductance measurements of the complexes were carried out using JENWAY -4520 at $25^{\circ} \mathrm{C}$ and $10^{-3} \mathrm{M}$ in DMSO.

The IR spectra of the ligands and their complexes were carried out using a Perking Elmer FT-IR spectrometer in 4000- $400 \mathrm{~cm}^{-1}$ range on $\mathrm{KBr}$ pellets. The electronic absorptions were measured with Jasco v-630 spectrophotometer in the range 190-1000 $\mathrm{nm}$ in DMSO solution $\left(10^{-4} \mathrm{M}\right)$. The magnetic measurements were carried out using SQUID magnetometer in 200-300 K range with an applied field 10,000 G. 
Thermogravimetric analysis (TGA) was obtained on a SDT Q 600 TA instrument in dynamic nitrogen atmosphere $\left(10^{\circ} \mathrm{C} . \mathrm{min}^{-1}\right.$ in $50-950^{\circ} \mathrm{C}$ temperature range $)$.

The cyclic voltammograms were conducted at room temperature with analyte concentrations of 1 $\mathrm{mM}$ in DMSO and tetrabutylammonium perchlorate (TBAP) as the supporting electrolyte. All solution were purged at least $15 \mathrm{~min}$ with nitrogen. The three electrodes system consisted of a platinum wire as the working electrode, a platinum foil as the counter electrode and a SCE (Saturated Calomel Electrode) as the reference electrode.

\subsection{Computational methods}

The Geometry optimization of the complexes in the ground state have been accomplished by Density Functional Theory (DFT) method using Beck's three parameters hybrid method and the Lee- Yang- Parr (B3LYP) correlation functional [30-32].

The LANL2DZ basis set was carried out for all atoms, as implemented by Gaussian 03W package [33] in gas phase. To make sure that the stationary points of the studied complexes were minima the vibrational frequencies were computed and their vibrational spectra were analyzed using Gaussview software.

The Natural Bond Orbital (NBO) program was used in order to perform the population analysis [34] at the same level of theory.

\subsection{Biological studies}

\subsubsection{Antimicrobial activity}

$\mathrm{L}^{1}-\mathrm{L}^{6}$ ligands and their nickel (II) complexes were screened in vitro for their antimicrobial activity using agar-well diffusion method $[35,36]$. The in vitro antibacterial activity was carried out in nutrient broth Mueller Hinton (MH) at $37^{\circ} \mathrm{C}$ for $24 \mathrm{~h}$, against two Gram-negative (E. Coli ATCC 4157, Klebsiella pneumonia ATCC 4352) and two Gram-positive (Staphylococcus aureus ATCC 6538, Streptocoque D ATCC 25923) bacterial strains. Whereas the antifungal activity was carried out in Sabouraud Dextrose Broth (SAB) at $28^{\circ} \mathrm{C}$ for $48 \mathrm{~h}$, against (Candida albicans ATCC 24433 and Trichophyton rubrum ATCC 1683)fungal strains. About $1 \mathrm{ml}$ of young bacterial and fungal inocula containing approximately $10^{6} \mathrm{CFU} / \mathrm{ml}$ Colony Forming Unite was spread on the surface of the nutrient agar and Sabouraud Dextrose Broth, with the help of a sterile cotton swab. The tested compounds were dissolved in DMSO solvent at concentration of 5 and $10 \mathrm{mg} / \mathrm{ml}$ [37, 38]. The wells $(6 \mathrm{~mm}$ in diameter) were punched carefully using a sterile Pipette Pasteur and $25 \mu \mathrm{L}$ of tested solutions at different concentrations were added into each labeled well. Other wells supplemented with DMSO and $\mathrm{Ni} \mathrm{Cl}_{2} .6 \mathrm{H}_{2} \mathrm{O}$ served as negative controls. 
The results are measuring by the diameter of the zones of inhibition that appeared around the wells. The sensitivity of the different compounds was classified by the diameter of the inhibition halos as: not sensitive for diameters less than $8 \mathrm{~mm}$; sensitive for diameters 9-14 mm; very sensitive for diameters 15-19 $\mathrm{mm}$ and extremely sensitive for diameters larger than $20 \mathrm{~mm}$ [39].

\subsubsection{Antioxidant studies}

The 2, 2-diphenyl-1-picryl-hydrazyl (DPPH) radical scavenging activity of the different ligands (L ${ }^{1}$ $\mathrm{L}^{6}$ ) and their nickel (II) complexes was measured according to the method of Blois [40]. The DPPH radical is a stable free radical that absorbs $(\lambda \max )$ at $517 \mathrm{~nm}$. A fixed concentration $(50 \mu \mathrm{M})$ of the tested compounds was added to a methanolic solution containing DPPH radicals $(1 \mathrm{mM}, 1 \mathrm{~mL})$. The final volume was $4 \mathrm{ml}$. the mixture was shaken vigorously and left in the dark for $30 \mathrm{~min}$. the decrease in absorbance of DPPH was measured at $517 \mathrm{~nm}$ using Jasco V-630 spectrophotometer. The same procedure was repeated for reference compound (Chlorogenic acid).

The antioxidant capacity of our products is expressed as percentage inhibition of the DPPH radical (\% of reduced DPPH) by the following relation [41]:

$$
\left.\% \text { scavenging effect }=\left[\left(\mathrm{A}_{\mathrm{DPPH}}-\mathrm{A}_{\mathrm{S}}\right)\right] / \mathrm{A}_{\mathrm{DPPH}}\right] \times 100
$$

$\mathrm{A}_{\mathrm{DPPH}}$ is the absorbance of DPPH in methanol.

$A_{S}$ is the absorbance of the tested compounds at $517 \mathrm{~nm}$.

Calibration curve of ascorbic acid (Fig S1, Supplementary Items) was plotted and used to estimate the antioxidant power of the ligands and their nickel (II) complexes, which will be expressed in ascorbic acid equivalent. 


\section{Results and discussion}

3.1. Physical properties of the metal complexes

The physical properties of the synthesized nickel (II) complexes are summarized in Table 1 . The molar conductivity measurements suggest that all the synthesized complexes are non-electrolytes [42-44] indicating that the two chloride are inside the metal coordination sphere. The complexes are green in color and are insoluble in water, ethanol and methanol but soluble in dimethyl Sulfoxide (DMSO) and N, N-dimethyl formamide (DMF).

Table 1. Physical properties of the metal complexes.

\begin{tabular}{|c|c|c|c|c|}
\hline Complexes & Melting point ${ }^{\circ} \mathrm{C}$ & Yield $\%$ & Conductance & $\begin{array}{c}\mu_{\mathrm{eff}} \\
(\mathrm{BM})\end{array}$ \\
\hline$\left[\mathrm{Ni} \mathrm{L}_{2}{ }_{2} \mathrm{Cl}_{2}\left(\mathrm{H}_{2} \mathrm{O}\right)_{2}\right] .2 \mathrm{H}_{2} \mathrm{O}$ & $>300$ & 55 & 18 & 3.01 \\
\hline$\left[\mathrm{Ni} \mathrm{L}_{2}{ }_{2} \mathrm{Cl}_{2}\left(\mathrm{H}_{2} \mathrm{O}\right)_{2}\right] .2 \mathrm{H}_{2} \mathrm{O}$ & $>300$ & 51 & 26 & 3.14 \\
\hline$\left[\mathrm{Ni} \mathrm{L}_{2}^{3} \mathrm{Cl}_{2}\left(\mathrm{H}_{2} \mathrm{O}\right)_{2}\right] \cdot 2 \mathrm{H}_{2} \mathrm{O}$ & $>300$ & 39 & 37 & 3.30 \\
\hline$\left[\mathrm{Ni} \mathrm{L}_{2}{ }_{2} \mathrm{Cl}_{2}\left(\mathrm{H}_{2} \mathrm{O}\right)_{2}\right] .2 \mathrm{H}_{2} \mathrm{O}$ & $>300$ & 46 & 41 & 3.41 \\
\hline$\left[\mathrm{Ni} \mathrm{L}_{2}{ }_{2} \mathrm{Cl}_{2}\left(\mathrm{H}_{2} \mathrm{O}\right)_{2}\right] .2 \mathrm{H}_{2} \mathrm{O}$ & $>300$ & 54 & 33 & 2.77 \\
\hline$\left[\mathrm{Ni} \mathrm{L}_{2}{ }_{2} \mathrm{Cl}_{2}\left(\mathrm{H}_{2} \mathrm{O}\right)_{2}\right] .2 \mathrm{H}_{2} \mathrm{O}$ & $>300$ & 56 & 13 & 2.82 \\
\hline
\end{tabular}

\subsection{Infrared spectra}

In order to determine the coordination site of our ligands, a comparison of the IR spectra of our ligands and their nickel complexes was carried out. From the IR spectra of the ligands and their complexes, we extracted some characteristic stretching vibration bands that could help and guide us to achieve this goal. Significant wave numbers are listed in Table 2. 
Table 2. The main absorbance bands $\left(\mathrm{cm}^{-1}\right)$ in FT-IR spectra and their assignments for the ligands and their complexes.

\begin{tabular}{|c|c|c|c|c|c|c|c|}
\hline Compound & $v(\mathrm{C}=\mathrm{N})_{\text {tetrazole }}$ & $v(\mathrm{~N}=\mathrm{N})$ & $v(\mathrm{~N}-\mathrm{N}=\mathrm{N})$ & $v(\mathrm{OH})_{\mathrm{H} 2 \mathrm{OCoord}}$ & $v(\mathrm{C}=\mathrm{O})$ & $v(\mathrm{M}-\mathrm{O})$ & $v(\mathrm{M}-\mathrm{N})$ \\
\hline \multirow[t]{2}{*}{$\mathrm{L}^{1}$} & 1510 & 1457 & 1329 & - & - & - & - \\
\hline & (1518) & (1459) & (1326) & & & & \\
\hline \multirow[t]{2}{*}{$\mathrm{L}^{2}$} & 1514 & 1461 & 1316 & - & - & - & - \\
\hline & (1497) & (1452) & (1311) & & & & \\
\hline \multirow[t]{2}{*}{$\mathrm{L}^{3}$} & 1489 & 1452 & 1326 & - & 1687 & - & - \\
\hline & (1481) & (1457) & (1330) & & (1691) & & \\
\hline \multirow[t]{2}{*}{$\mathrm{L}^{4}$} & 1494 & 1456 & 1309 & - & 1683 & - & - \\
\hline & (1491) & (1465) & (1311) & & (1681) & & \\
\hline \multirow[t]{2}{*}{$\mathrm{L}^{5}$} & 1483 & 1447 & 1319 & - & - & - & - \\
\hline & (1476) & (1466) & (1318) & & & & \\
\hline \multirow[t]{2}{*}{ L6 } & 1488 & 1452 & 1284 & - & - & - & - \\
\hline & (1482) & (1458) & (1278) & & & & \\
\hline \multirow[t]{2}{*}{$\mathrm{Ni}-\mathrm{L}^{1}$} & 1500 & 1431 & 1254 & 3479 & - & 467 & 525 \\
\hline & (1492) & (1418) & (1252) & (3526) & & (424) & (521) \\
\hline \multirow[t]{2}{*}{$\mathrm{Ni}-\mathrm{L}^{2}$} & 1475 & 1416 & 1265 & 3468 & - & 464 & 524 \\
\hline & (1474) & (1416) & (1267) & (3515) & & (423) & (545) \\
\hline \multirow[t]{2}{*}{$\mathrm{Ni}-\mathrm{L}^{3}$} & 1473 & 1418 & 1252 & 3477 & 1637 & 471 & 522 \\
\hline & (1463) & (1401) & (1258) & (3542) & (1643) & (433) & (518) \\
\hline \multirow[t]{2}{*}{$\mathrm{Ni}-\mathrm{L}^{4}$} & 1480 & 1410 & 1263 & 3448 & 1631 & 465 & 523 \\
\hline & (1470) & (1397) & (1259) & (3545) & (1634) & (431) & (531) \\
\hline \multirow[t]{2}{*}{$\mathrm{Ni}-\mathrm{L}^{5}$} & 1483 & 1418 & 1258 & 3467 & - & 464 & 536 \\
\hline & (1481) & (1409) & (1264) & (3539) & & (449) & (538) \\
\hline \multirow[t]{2}{*}{$\mathrm{Ni}-\mathrm{L}^{6}$} & 1475 & 1408 & 1271 & 3467 & - & 464 & 525 \\
\hline & (1470) & (1410) & (1285) & (3531) & & (450) & (543) \\
\hline
\end{tabular}

$($ Calc $)=$ Calculated by DFT

The IR spectrum of each free ligand show a characteristic absorption bands near $1300 \mathrm{~cm}^{-1}$ assigned to $(-\mathrm{N}-\mathrm{N}=\mathrm{N}-)$ stretching vibration of the tetrazole ring [45-47], a medium intensity bands in the region 1447-1510 $\mathrm{cm}^{-1}$ which might be due to $(\mathrm{C}=\mathrm{N})$ tetrazole and $(\mathrm{N}=\mathrm{N})$ stretching vibration of the tetrazole ring [48]. The $(\mathrm{C}=\mathrm{O})$ stretching vibration band is observed at 1687 and $1683 \mathrm{~cm}^{-1}$ for $\mathrm{L}^{3}$ and $\mathrm{L}^{4}$ ligands, respectively [49]. 


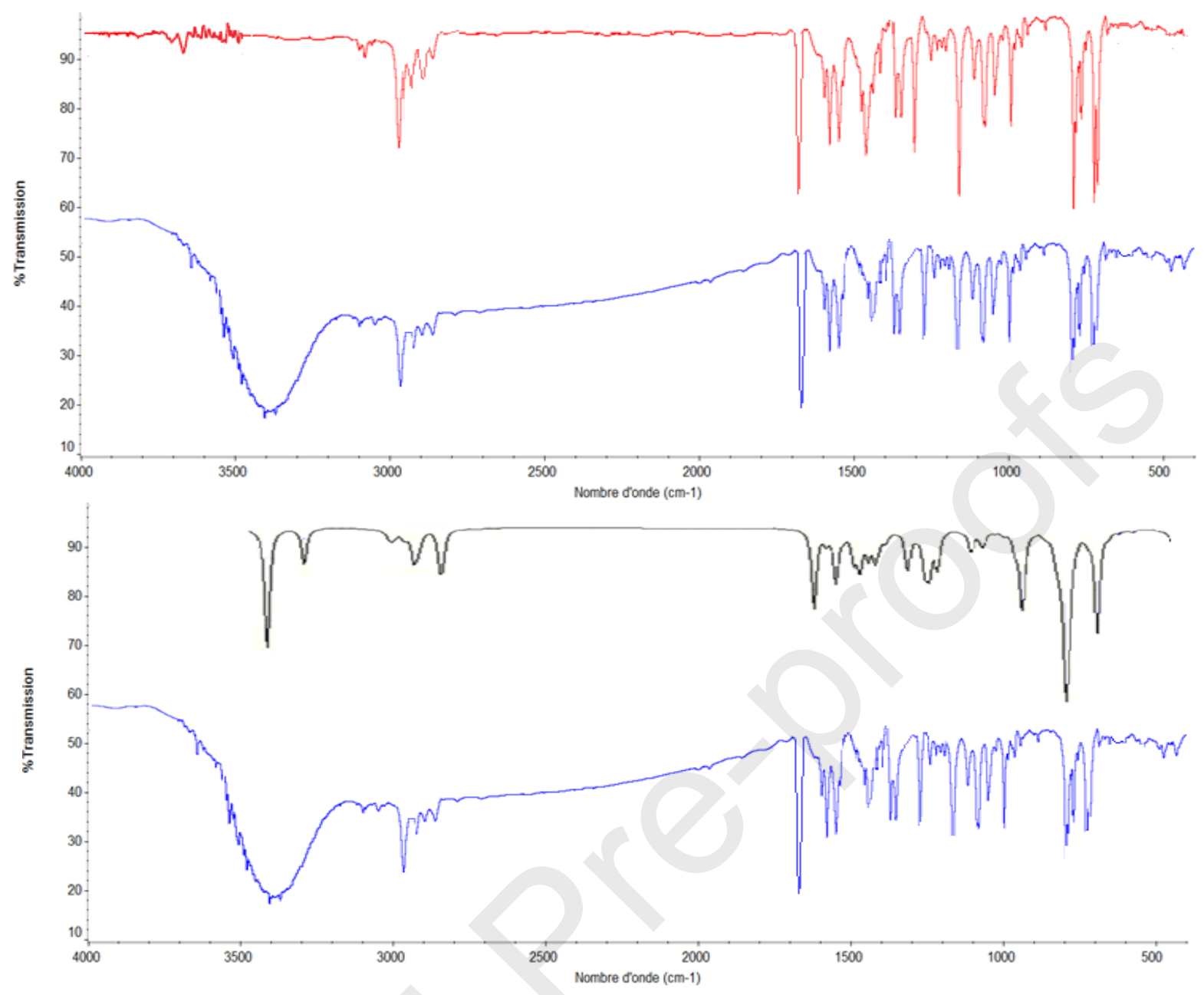

Fig. 1.Experimental Infrared vibrational spectra of $\mathrm{L}^{4}$ ligand (red line) and $\mathrm{Ni}-\mathrm{L}^{4}$ complex (blue line) and Simulated IR spectrum of $\mathrm{Ni}-\mathrm{L}^{4}$ complex (black line).

The results presented in Table 2 showed that $(\mathrm{C}=\mathrm{N})$ tetrazole, $(\mathrm{N}=\mathrm{N})$ and $(\mathrm{N}-\mathrm{N}=\mathrm{N})$ stretching vibrations of the varied ligands are different. This leads us to assume that the difference between these stretching vibrations is due to the electronic effect of the substituents located in position 1 and5 on the ligands (scheme 1) [50,51]. It is expected that the position and/ or the intensity of these absorption bands will be changed upon complexation.

The IR spectra of the complexes reveal that the stretching vibration band of $(\mathrm{N}=\mathrm{N})$ is affected by complexation and shifted toward lower frequencies by $26-46 \mathrm{~cm}^{-1}$, the shift to lower frequencies of $(\mathrm{N}-\mathrm{N}=\mathrm{N})$ band is observed for all complexes by $58-75 \mathrm{~cm}^{-1}$ and a slight shift appeared toward lower frequencies for $(\mathrm{C}=\mathrm{N})$ tetrazole stretching vibration band. The big shift toward lower frequencies of $(\mathrm{N}=\mathrm{N})$ and $(\mathrm{N}-\mathrm{N}=\mathrm{N})$ stretching vibrations bands and the slight shift of $(\mathrm{C}=\mathrm{N})$ band of the coordinated ligands leads us to deduce the involvement of $(\mathrm{N}=\mathrm{N})$ group in the complexation. It is 
also noted that $(\mathrm{C}=\mathrm{O})$ stretching vibration for both $\mathrm{L}^{3}$ and $\mathrm{L}^{4}$ ligands remained unaffected by the complexation which indicates that this group was not involved in the coordination.

The bonding between ligand and metal ion is also confirmed by the presence of new bands in the IR spectra of the complexes around 450 and $520 \mathrm{~cm}^{-1}$ assigned to M-O and M-N, respectively [52]. The stretching vibration of coordinated water molecules appeared in the range $3448-3479 \mathrm{~cm}^{-1}$ [53]. The theoretical IR spectra were obtained with the help of DFT calculations using B3LYP method with the LANL2DZ basis set. The simulated and experimental IR spectra of ligands and their nickel (II) complexes are presented in Fig. 1. The nickel (II) complexes IR spectra are in good agreement with the experimental spectra. These spectra were used to confirm the experimental assignments.

\subsection{Electronic spectra}

The electronic spectra of the different ligands $\left(\mathrm{L}^{1}-\mathrm{L}^{6}\right)$ and their nickel (II) complexes are measured in DMSO solution and presented in table 3 and 4 respectively, and the electronic absorption spectra of $\mathrm{L}^{5}$ ligand and the corresponding Ni (II) complex are given in fig. 2.

It is noted from Table3 that all the ligands exhibit absorption bands and shoulders between $240 \mathrm{~nm}$ $\left(41667 \mathrm{~cm}^{-1}\right)$ and $325 \mathrm{~nm}\left(30769 \mathrm{~cm}^{-1}\right)$ and they are due to the intraligand transitions $\pi \rightarrow \pi^{*}$ and $\mathrm{n} \rightarrow \pi^{*}$ respectively [54].

Table 3. The main absorbance bands $\left(\mathrm{cm}^{-1}\right)$ of the ligands in UV-visible and their assignments.

\begin{tabular}{llll}
\hline Ligand & $\lambda \mathrm{nm}\left(\mathrm{cm}^{-1}\right)$ & $\varepsilon\left(\mathrm{mole}^{-1} . \mathrm{L} . \mathrm{cm}^{-1}\right)$ & Electronic transitions \\
\hline $\mathrm{L}^{1}$ & $273(36630)$ & 30300 & $\pi \rightarrow \pi^{*}$ \\
& $315(31055)$ & 14500 & $\mathrm{n} \rightarrow \pi^{*}$ \\
\hline $\mathrm{L}^{2}$ & $246(40650)$ & 14270 & $\pi \rightarrow \pi^{*}$ \\
& $317(31545)$ & 22900 & $\mathrm{n} \rightarrow \pi^{*}$ \\
\hline $\mathrm{L}^{3}$ & $250(40000)$ & 14890 & $\pi \rightarrow \pi^{*}$ \\
& $302(33557)$ & 18300 & $\pi \rightarrow \pi^{*}$ \\
\hline $\mathrm{L}^{4}$ & $244(40983)$ & 11330 & $\pi \rightarrow \pi^{*}$ \\
& $282(35971)$ & 28200 & $\mathrm{n} \rightarrow \pi^{*}$ \\
\hline $\mathrm{L}^{5}$ & $281(35587)$ & 34600 & $\pi \rightarrow \pi^{*}$ \\
& $316(31646)$ & 22100 & $\mathrm{n} \rightarrow \pi^{*}$ \\
\hline $\mathrm{L}^{6}$ & $275(36101)$ & 68800 & $\pi \rightarrow \pi^{*}$ \\
& $324(30864)$ & 16700 & $\mathrm{n} \rightarrow \pi^{*}$ \\
\hline
\end{tabular}


A band at $275 \mathrm{~nm}$ and a shoulder between $300-330 \mathrm{~nm}$ are showed on $\mathrm{L}^{1}$ spectrum. $\mathrm{L}^{2}$ spectrum presents also a band at $246 \mathrm{~nm}$ and a shoulder between $300-330 \mathrm{~nm}$.

$\mathrm{L}^{3}$ spectrum exhibits a band at $250 \mathrm{~nm}$ and a shoulder between $295-310 \mathrm{~nm}$. $\mathrm{L}^{4}$ spectrum presents a shoulder between 240-250 $\mathrm{nm}$ and another one between 275-290 $\mathrm{nm}$.

$\mathrm{L}^{5}$ spectrum shows two shoulders between $275-290 \mathrm{~nm}$ and between $310-320 \mathrm{~nm}$. $\mathrm{L}^{6}$ spectrum exhibits also two shoulders the first one between 265-280nm and the second one between 315 $330 \mathrm{~nm}$.

The difference in the observed electronic absorptions could be related to the different electronic effect of the substituents (Benzyl, Pivaloyl and Methyl) located in position 1 and ([2-(2-ethyl-4methylthiazol) phenyl], [2-(1-methyl pyrrol-2-yl) phenyl]) located in position 5 of the ligands (scheme 1) [55, 56].

It is also noted from Table 3 that $\mathrm{L}^{1}, \mathrm{~L}^{3}$ and $\mathrm{L}^{5}$ ligands show electronic absorptions at higher wavelengths in comparison to $\mathrm{L}^{2}, \mathrm{~L}^{4}$ and $\mathrm{L}^{6}$ ligands. The higher electron donating effect of ([2-(2ethyl-4-methylthiazol) phenyl] group carried by $\mathrm{L}^{1}, \mathrm{~L}^{3}$ and $\mathrm{L}^{5}$ ligands in position 5 could explain this result. $\mathrm{L}^{3}$ and $\mathrm{L}^{4}$ ligands show electronic absorptions at the smallest wavelengths; this is attributed to the higher electron withdrawing effect of the Pivaloyl substituent located in position 1 of the ligands [57].
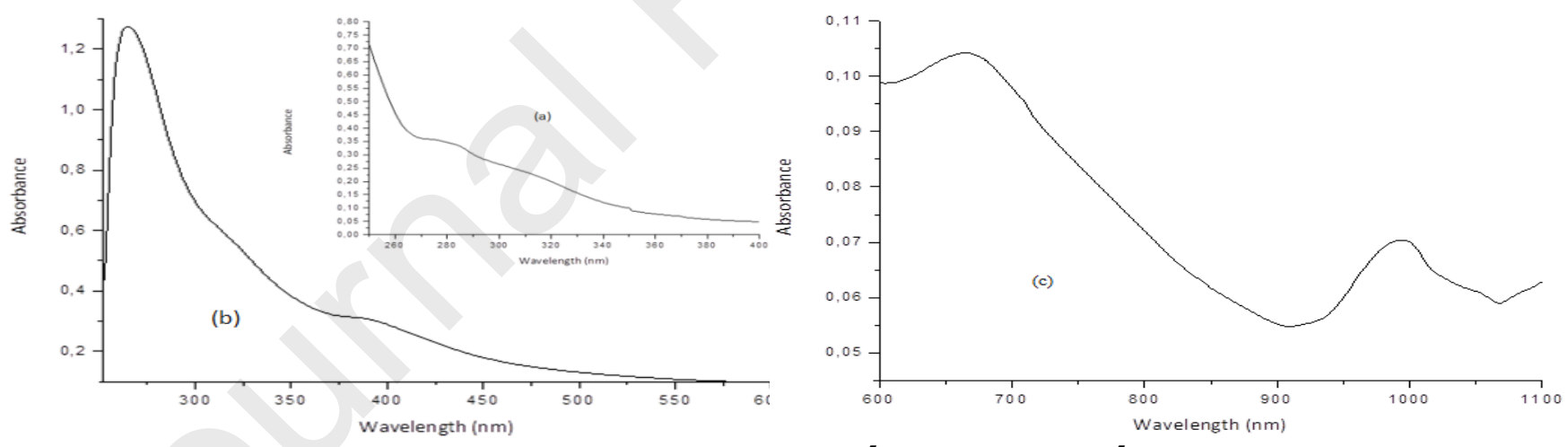

Fig. 2.Electronic spectra of (a) $\mathrm{L}^{5}$ and $(b+c) N i-L^{5}$

The electronic data of the complexes are summarized in Table 4.Five absorption bands are observed for all complexes. Two are located in UV region in the range $260-280 \mathrm{~nm}$ and $315-335 \mathrm{~nm}$ due to the $\pi \rightarrow \pi^{*}$ and $n \rightarrow \pi^{*}$ intraligand transitions $[30,37]$ and are displaced with respect in the ligands. This indicates that the ligands are present around the central metal.

Three bands present in the range $380-395 \mathrm{~nm}, 660-685 \mathrm{~nm}$ and $980-1000 \mathrm{~nm}$ could be attributed to ${ }^{3} \mathrm{~A}_{2 \mathrm{~g}}(\mathrm{~F}) \rightarrow{ }^{3} \mathrm{~T}_{2 \mathrm{~g}}(\mathrm{~F}),{ }^{3} \mathrm{~A}_{2 \mathrm{~g}}(\mathrm{~F}) \rightarrow{ }^{3} \mathrm{~T}_{1 \mathrm{~g}}(\mathrm{~F})$ and ${ }^{3} \mathrm{~A}_{2 \mathrm{~g}}(\mathrm{~F}) \rightarrow{ }^{3} \mathrm{~T}_{2 \mathrm{~g}}(\mathrm{P}) \mathrm{d}-\mathrm{d}$ transitions, respectively. These absorption ranges correspond to the composition of well-selected octahedral configuration around Ni (II) [58-60]. The observed magnetic moment values (table 1) of nickel complexes indicate the 
paramagnetic nature of $\mathrm{Ni}$ (II), which confirms the octahedral structure of these nickel complexes $[30,37,38]$.

Table 4. The main absorbance bands $\left(\mathrm{cm}^{-1}\right)$ of $\mathrm{Ni}$ (II) complexes in UV-visible and their assignments.

\begin{tabular}{|c|c|c|c|c|}
\hline Compounds & $\begin{array}{c}\text { Wavenumber } \\
\bar{v}\left(\mathrm{~cm}^{-1}\right)\end{array}$ & $\begin{array}{l}\text { Wavelength } \\
\lambda(\mathrm{nm})\end{array}$ & $\begin{array}{l}\text { Molar coefficient absorption } \\
\qquad\left(\mathrm{mole}^{-1} . \mathrm{L} \cdot \mathrm{cm}^{-1}\right)\end{array}$ & Electronic transition \\
\hline \multirow{5}{*}{$\mathrm{Ni}-\mathrm{L}^{1}$} & 37735 & 265 & 1009 & $\pi \rightarrow \pi^{*}$ \\
\hline & 31055 & 322 & 583 & $\mathrm{n} \rightarrow \pi^{*}$ \\
\hline & 25316 & 395 & 302 & ${ }^{3} \mathrm{~A}_{2 \mathrm{~g}}(\mathrm{~F}) \rightarrow{ }^{3} \mathrm{~T}_{2 \mathrm{~g}}(\mathrm{~F})$ \\
\hline & 15060 & 664 & 110 & ${ }^{3} \mathrm{~A}_{2 \mathrm{~g}}(\mathrm{~F}) \rightarrow{ }^{3} \mathrm{~T}_{1 \mathrm{~g}}(\mathrm{~F})$ \\
\hline & 10080 & 992 & 78 & ${ }^{3} \mathrm{~A}_{2 \mathrm{~g}}(\mathrm{~F}) \rightarrow{ }^{3} \mathrm{~T}_{2 \mathrm{~g}}(\mathrm{P})$ \\
\hline \multirow{5}{*}{$\mathrm{Ni}-\mathrm{L}^{2}$} & 36630 & 273 & 833 & $\pi \rightarrow \pi^{*}$ \\
\hline & 30303 & 330 & 490 & $\mathrm{n} \rightarrow \pi^{*}$ \\
\hline & 25706 & 389 & 343 & ${ }^{3} \mathrm{~A}_{2 \mathrm{~g}}(\mathrm{~F}) \rightarrow{ }^{3} \mathrm{~T}_{2 \mathrm{~g}}(\mathrm{~F})$ \\
\hline & 14925 & 670 & 154 & ${ }^{3} \mathrm{~A}_{2 \mathrm{~g}}(\mathrm{~F}) \rightarrow{ }^{3} \mathrm{~T}_{1 \mathrm{~g}}(\mathrm{~F})$ \\
\hline & 10152 & 985 & 112 & ${ }^{3} \mathrm{~A}_{2 \mathrm{~g}}(\mathrm{~F}) \rightarrow{ }^{3} \mathrm{~T}_{2 \mathrm{~g}}(\mathrm{P})$ \\
\hline \multirow{5}{*}{$\mathrm{Ni}-\mathrm{L}^{3}$} & 36496 & 274 & 718 & $\pi \rightarrow \pi^{*}$ \\
\hline & 30864 & 324 & 453 & $\mathrm{n} \rightarrow \pi^{*}$ \\
\hline & 25575 & 391 & 287 & ${ }^{3} \mathrm{~A}_{2 \mathrm{~g}}(\mathrm{~F}) \rightarrow{ }^{3} \mathrm{~T}_{2 \mathrm{~g}}(\mathrm{~F})$ \\
\hline & 15015 & 666 & 145 & ${ }^{3} \mathrm{~A}_{2 \mathrm{~g}}(\mathrm{~F}) \rightarrow{ }^{3} \mathrm{~T}_{1 \mathrm{~g}}(\mathrm{~F})$ \\
\hline & 10141 & 986 & 111 & ${ }^{3} \mathrm{~A}_{2 \mathrm{~g}}(\mathrm{~F}) \rightarrow{ }^{3} \mathrm{~T}_{2 \mathrm{~g}}(\mathrm{P})$ \\
\hline \multirow{5}{*}{$\mathrm{Ni}-\mathrm{L}^{4}$} & 40816 & 275 & 938 & $\pi \rightarrow \pi^{*}$ \\
\hline & 31446 & 318 & 736 & $\mathrm{n} \rightarrow \pi^{*}$ \\
\hline & 25641 & 390 & 402 & ${ }^{3} \mathrm{~A}_{2 \mathrm{~g}}(\mathrm{~F}) \rightarrow{ }^{3} \mathrm{~T}_{2 \mathrm{~g}}(\mathrm{~F})$ \\
\hline & 14771 & 677 & 160 & ${ }^{3} \mathrm{~A}_{2 \mathrm{~g}}(\mathrm{~F}) \rightarrow{ }^{3} \mathrm{~T}_{1 \mathrm{~g}}(\mathrm{~F})$ \\
\hline & 10141 & 986 & 101 & ${ }^{3} \mathrm{~A}_{2 \mathrm{~g}}(\mathrm{~F}) \rightarrow{ }^{3} \mathrm{~T}_{2 \mathrm{~g}}(\mathrm{P})$ \\
\hline \multirow{5}{*}{$\mathrm{Ni}-\mathrm{L}^{5}$} & 37735 & 265 & 1273 & $\pi \rightarrow \pi^{*}$ \\
\hline & 30864 & 324 & 547 & $\mathrm{n} \rightarrow \pi^{*}$ \\
\hline & 25316 & 395 & 304 & ${ }^{3} \mathrm{~A}_{2 \mathrm{~g}}(\mathrm{~F}) \rightarrow{ }^{3} \mathrm{~T}_{2 \mathrm{~g}}(\mathrm{~F})$ \\
\hline & 15015 & 666 & 104 & ${ }^{3} \mathrm{~A}_{2 \mathrm{~g}}(\mathrm{~F}) \rightarrow{ }^{3} \mathrm{~T}_{1 \mathrm{~g}}(\mathrm{~F})$ \\
\hline & 10070 & 993 & 70 & ${ }^{3} \mathrm{~A}_{2 \mathrm{~g}}(\mathrm{~F}) \rightarrow{ }^{3} \mathrm{~T}_{2 \mathrm{~g}}(\mathrm{P})$ \\
\hline \multirow{5}{*}{$\mathrm{Ni}-\mathrm{L}^{6}$} & 37735 & 265 & 1000 & $\pi \rightarrow \pi^{*}$ \\
\hline & 30769 & 325 & 483 & $\mathrm{n} \rightarrow \pi^{*}$ \\
\hline & 25316 & 395 & 321 & ${ }^{3} \mathrm{~A}_{2 \mathrm{~g}}(\mathrm{~F}) \rightarrow{ }^{3} \mathrm{~T}_{2 \mathrm{~g}}(\mathrm{~F})$ \\
\hline & 14992 & 667 & 139 & ${ }^{3} \mathrm{~A}_{2 \mathrm{~g}}(\mathrm{~F}) \rightarrow{ }^{3} \mathrm{~T}_{1 \mathrm{~g}}(\mathrm{~F})$ \\
\hline & 10091 & 991 & 97 & ${ }^{3} \mathrm{~A}_{2 \mathrm{~g}}(\mathrm{~F}) \rightarrow{ }^{3} \mathrm{~T}_{2 \mathrm{~g}}(\mathrm{P})$ \\
\hline
\end{tabular}




\subsection{Thermogravimetric analysis}

The thermogravimetric analysis (TGA) for the different complexes was carried out using SDT Q600 TA Instrument. Heated from $50-950^{\circ} \mathrm{C}$ in a covered Aluminum sample holders. A heating rate of $10^{\circ} \mathrm{C}$ per min was employed and $100 \mathrm{ml}$ per min dynamic nitrogen atmosphere. The thermogravimetric data of the complexes are summarized in Table 5.

The TGA curves of the complexes are very similar and that of $\mathrm{Ni}^{-\mathrm{L}^{1}}$ (Fig. 3) and Ni-L ${ }^{4}$ (Fig S2, Supplementary Items) were discussed as examples.

Table5.Thermogravimetric results of the complexes.

\begin{tabular}{|c|c|c|c|c|c|}
\hline \multirow[t]{2}{*}{ Complexes } & \multirow[t]{2}{*}{ Steps } & \multirow[t]{2}{*}{ Temperature $\left({ }^{\circ} \mathrm{C}\right)$} & \multirow{2}{*}{$\begin{array}{l}\text { Leaving } \\
\text { group }\end{array}$} & \multicolumn{2}{|l|}{ Mass Loss $\%$} \\
\hline & & & & Expt & Calc \\
\hline \multirow{4}{*}[\mathrm{Ni}\mathrm{L}_{2}{}_{2}\mathrm{Cl}_{2}(\mathrm{H}_{2}\mathrm{O})_{2}]{$.2 \mathrm{H} 2 \mathrm{O}$} & 1 & $50-160$ & $\mathrm{H}_{2} \mathrm{O}$ & 8.1 & 7.23 \\
\hline & $2+3$ & $160-356+356-565$ & $\mathrm{~L}_{2}$ & $44.1+25.2$ & $45.84+20.7+5.63$ \\
\hline & \multirow[t]{2}{*}{4} & \multirow[t]{2}{*}{$565-767$} & $\mathrm{Cl}_{2}$ & 7.8 & 7.127 \\
\hline & & & $\mathrm{NiO}$ & 8.5 & 7.49 \\
\hline \multirow{4}{*}[\mathrm{Ni}\mathrm{L}_{2}{}_{2}\mathrm{Cl}_{2}(\mathrm{H}_{2}\mathrm{O})_{2}]{$.2 \mathrm{H} 2 \mathrm{O}$} & 1 & $50-173$ & $\mathrm{H}_{2} \mathrm{O}$ & 8.9 & 8.27 \\
\hline & $2+3$ & $173-560$ & $\mathrm{~L}_{2}$ & $40.1+28.3$ & $41.82+23.66+6.43$ \\
\hline & \multirow[t]{2}{*}{4} & \multirow{2}{*}{$560-850$} & $\mathrm{Cl}_{2}$ & 7.9 & 8.145 \\
\hline & & & $\mathrm{NiO}$ & 11.3 & 10.515 \\
\hline \multirow{4}{*}[\mathrm{Ni}\mathrm{L}^{3}{}_{2}\mathrm{Cl}_{2}(\mathrm{H}_{2}\mathrm{O})_{2}]{$.2 \mathrm{H} 2 \mathrm{O}$} & \multirow{4}{*}{$\begin{array}{l}1 \\
2+3\end{array}$} & \multirow{4}{*}{$\begin{array}{l}50-190 \\
190-460 \\
460-870\end{array}$} & $\mathrm{H}_{2} \mathrm{O}$ & 8.4 & 7.64 \\
\hline & & & $\mathrm{L}_{2}$ & $56.7+16.6$ & $57.53+11.46+5.94$ \\
\hline & & & $\mathrm{Cl}_{2}$ & 7.3 & 7.53 \\
\hline & & & $\mathrm{NiO}$ & 8.6 & 8.62 \\
\hline \multirow{4}{*}[\mathrm{Ni}\mathrm{L}_{2}{}_{2}\mathrm{Cl}_{2}(\mathrm{H}_{2}\mathrm{O})_{2}]{$.2 \mathrm{H} 2 \mathrm{O}$} & \multirow{4}{*}{$\begin{array}{l}1 \\
2+3\end{array}$} & $50-176$ & $\mathrm{H}_{2} \mathrm{O}$ & 8.7 & 8.29 \\
\hline & & $176-334+334-444$ & $\mathrm{~L}_{2}$ & $52.3+17.3$ & $51.34+12.16+6.30$ \\
\hline & & \multirow[t]{2}{*}{ 444-900 } & $\mathrm{Cl}_{2}$ & 7.9 & 7.98 \\
\hline & & & $\mathrm{NiO}$ & 8.5 & 8.608 \\
\hline \multirow{4}{*}[\mathrm{Ni}\mathrm{L}_{2}{}_{2}\mathrm{Cl}_{2}(\mathrm{H}_{2}\mathrm{O})_{2}]{$.2 \mathrm{H} 2 \mathrm{O}$} & 1 & $50-201$ & $\mathrm{H}_{2} \mathrm{O}$ & 10.7 & 9.03 \\
\hline & $2+3$ & $201-430+430-557$ & $\mathrm{~L}_{2}$ & $57.9+13.4$ & $57.21+6.77+7.02$ \\
\hline & \multirow[t]{2}{*}{4} & \multirow[t]{2}{*}{$557-828$} & $\mathrm{Cl}_{2}$ & 7.2 & 8.89 \\
\hline & & & $\mathrm{NiO}$ & 10.7 & 9.369 \\
\hline \multirow{4}{*}[\mathrm{Ni}\mathrm{L}_{2}{}_{2}\mathrm{Cl}_{2}(\mathrm{H}_{2}\mathrm{O})_{2}]{$.2 \mathrm{H} 2 \mathrm{O}$} & 1 & $50-179$ & $\mathrm{H}_{2} \mathrm{O}$ & 10.2 & 9.62 \\
\hline & 2 & $179-548$ & $\mathrm{~L}_{2}$ & 63.3 & $48+7.214+7.48$ \\
\hline & \multirow[t]{2}{*}{3} & \multirow[t]{2}{*}{$548-815$} & $\mathrm{Cl}_{2}$ & 8.6 & 9.47 \\
\hline & & & $\mathrm{NiO}$ & 9.3 & 9.95 \\
\hline
\end{tabular}

Based on the literature, mechanisms of the thermal decomposition for $\mathrm{Ni}^{-\mathrm{L}^{1}}$ and $\mathrm{Ni}-\mathrm{L}^{4}$ complexes are proposed and presented in Fig. 4 and (Fig S3, Supplementary Items), respectively. The 
decomposition of tetrazole derivatives is via Azide isomers followed by the elimination of nitrogen molecule and the formation of the corresponding nitrenes which are unstable [61, 62].

The TGA curve of Ni-L ${ }^{1}$ complex Fig. 3 shows four (4) stages in the decomposition process. The first stage of weight loss is observed in the range of temperature $50-160^{\circ} \mathrm{C}$ with a mass 10 ss of $8.1 \%$ correspond to the loss of hydrated and coordinated water molecules (calc 7. 23\%).

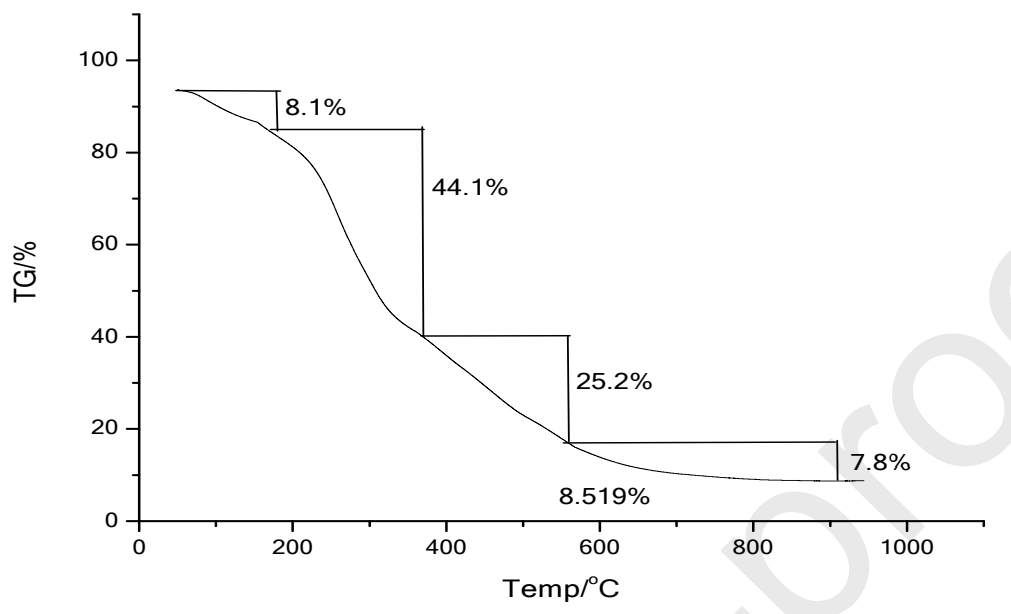

Fig. 3.Thermal decomposition of $\mathrm{Ni}-\mathrm{L}^{1}$.

In the rage $160-565^{\circ} \mathrm{C}$ the organic moiety decompose in tow stage, the first one $160-356^{\circ} \mathrm{C}$ correspond to compound 2 (Fig.4) with mass loss of $44.1 \%$ (calc $45.84 \%$ ). whereas the second stage $356-565^{\circ} \mathrm{C}$ due to compounds $1+3$ (Fig. 4) presents the rest of the ligands with mass loss of $25.2 \%$ (calc 26.33\%).

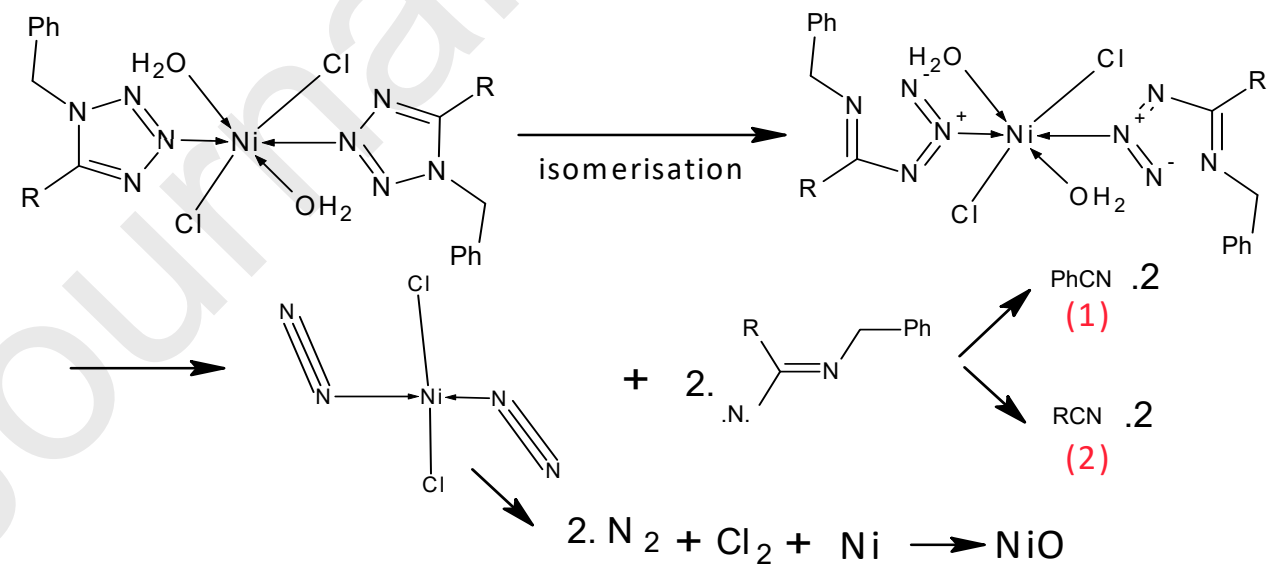

(3)

Fig. 4. Mechanism of the thermal decomposition of Ni-L ${ }^{1}$.

The last stage $565-767^{\circ} \mathrm{C}$ corresponds to the weight loss of two Chloride ions with a mass loss of $7.8 \%$ (calc $7.127 \%$ ). The TGA curve indicates a residual mass of $8.5 \%$ corresponding to the formation of metal oxide $\mathrm{NiO}$ (calc 7. 49\%). these finding are similar to the one that reported for nickel complexes [63]. 
The TGA curve of Ni-L ${ }^{4}$ complex (Fig S2, Supplementary Items) exhibited $8.7 \%$ of weight loss (calc $8.29 \%$ ) in the range $50-176^{\circ} \mathrm{C}$ due to loss of hydrated and coordinated water molecules.

The next stage of decomposition is seen in the range $176-334^{\circ} \mathrm{C}$, which corresponds to partial decomposition of the ligand (compound 1) (Fig S3, Supplementary Items), with mass loss of 52.3\% (calc 51.34\%). The final decomposition of the ligand (compounds 2+3) (Fig S3, Supplementary Items), is seen in the range $334-444^{\circ} \mathrm{C}$ with mass loss of $17.3 \%$ (calc $12.16+6.30 \%$ ). The last stage $444-900^{\circ} \mathrm{C}$ corresponds to the weight loss of two Chloride ions with a mass loss of $7.9 \%$ (calc $7.98 \%$ ). The curve indicates a residual mass of $8.5 \%$ corresponding to the formation of metal oxide $\mathrm{NiO}$ (calc 8.608\%). This finding is similar to the one that reported for nickel complexes [63].

According to the results presented in Table 5, the $\mathrm{Ni}-\mathrm{L}^{5}$ and $\mathrm{Ni}-\mathrm{L}^{6}$ complexes undergo decomposition at a higher temperature than the rest of the complexes. This indicates that $\mathrm{L}^{5}$ and $\mathrm{L}^{6}$ ligands give the most stable complexes with Ni (II). 


\subsection{Theoretical calculations}

\subsubsection{Geometry}

Based on the analytical and spectral characterization results an octahedral geometry was suggested for all complexes.

Table 6.Calculated structural parameters and NBO charge of the ligands and their complexes.

\begin{tabular}{|c|c|c|c|c|c|c|}
\hline Parameters & $\mathrm{L}^{1}$ & $\mathrm{~L}^{2}$ & $\mathrm{~L}^{3}$ & $\mathrm{~L}^{4}$ & $\mathrm{~L}^{5}$ & $\mathrm{~L}^{6}$ \\
\hline \multicolumn{7}{|l|}{ Bond lengths $(\AA)$} \\
\hline $\mathrm{N} 3-\mathrm{N} 2$ & 1.332 & 1.330 & 1.316 & 1.314 & 1.332 & 1.332 \\
\hline N3-N4 & 1.395 & 1.396 & 1.408 & 1.409 & 1.395 & 1.396 \\
\hline \multicolumn{7}{|l|}{ Dihedral angles $\left({ }^{\circ}\right)$} \\
\hline N2-N3-N4-C1 & 0.2 & 0.2 & 0.5 & 0.2 & 0.4 & 0.3 \\
\hline \multicolumn{7}{|l|}{ NBO Charge (e) } \\
\hline N3 & -0.058 & -0.059 & -0.027 & -0.025 & -0.059 & -0.061 \\
\hline Parameters & Ni-L ${ }^{1}$ & $\mathrm{Ni}-\mathrm{L}^{2}$ & Ni-L ${ }^{3}$ & $\mathrm{Ni}-\mathrm{L}^{4}$ & Ni-L ${ }^{5}$ & $\mathrm{Ni}-\mathrm{L}^{6}$ \\
\hline \multicolumn{7}{|l|}{ Bond length $(\AA)$} \\
\hline Ni-N3 & 2.093 & 2.121 & 2.095 & 2.099 & 2.094 & 2.099 \\
\hline Ni-N48 & 2.091 & 2.095 & 2.102 & 2.099 & 2.109 & 2.116 \\
\hline $\mathrm{Ni}-\mathrm{Cl} 192$ & 2.423 & 2.439 & 2.405 & 2.407 & 2.407 & 2.419 \\
\hline $\mathrm{Ni}-\mathrm{Cl} 193$ & 2.523 & 2.500 & 2.497 & 2.496 & 2.518 & 2.508 \\
\hline Ni-O94 & 2.102 & 2.093 & 2.099 & 2.098 & 2.098 & 2.094 \\
\hline Ni-O96 & 2.108 & 2.096 & 2.099 & 2.101 & 2.101 & 2.102 \\
\hline N3-N2 & 1.321 & 1.320 & 1.308 & 1.306 & 1.321 & 1.321 \\
\hline N48-N47 & 1.321 & 1.320 & 1.308 & 1.307 & 1.322 & 1.322 \\
\hline N3-N4 & 1.389 & 1.390 & 1.398 & 1.398 & 1.386 & 1.388 \\
\hline N48-N49 & 1.388 & 1.389 & 1.399 & 1.399 & 1.388 & 1.390 \\
\hline \multicolumn{7}{|l|}{ Bond angles $\left({ }^{\circ}\right)$} \\
\hline N3-Ni-N48 & 175.6 & 172.7 & 174.2 & 173.4 & 176.7 & 174.3 \\
\hline C192-Ni-C193 & 179.0 & 178.5 & 177.9 & 179.4 & 178.2 & 179.7 \\
\hline O94-Ni-O96 & 163.9 & 165.7 & 165.3 & 165.4 & 165.1 & 165.1 \\
\hline N3-Ni-C192 & 86.0 & 85.2 & 86.9 & 87.1 & 89.3 & 88.4 \\
\hline N48-Ni-C193 & 89.5 & 91.3 & 94.6 & 93.2 & 94.1 & 94.1 \\
\hline N3-Ni-C193 & 94.7 & 96.0 & 91.2 & 93.4 & 89.1 & 91.6 \\
\hline N48-Ni-C192 & 89.7 & 87.5 & 87.3 & 86.3 & 87.5 & 85.9 \\
\hline O94-Ni-N3 & 85.8 & 94.9 & 94.7 & 94.8 & 94.5 & 95.7 \\
\hline O96-Ni-N48 & 85.4 & 95.9 & 94.3 & 94.8 & 94.6 & 94.5 \\
\hline O94-Ni-C192 & 98.7 & 96.3 & 98.3 & 97.0 & 97.9 & 96.9 \\
\hline O96-Ni-C193 & 81.9 & 82.9 & 82.4 & 82.6 & 82.2 & 82.3 \\
\hline \multicolumn{7}{|l|}{ Dihedral angles $\left({ }^{\circ}\right)$} \\
\hline N3-Ni-N48-N47 & 78.6 & 85.6 & 83.4 & 78.7 & 91.8 & 74.4 \\
\hline N48-Ni-N3-N2 & 89.9 & 75.8 & 87.6 & 90.6 & 83.2 & 92.5 \\
\hline N2-N3-N4-Ni & 160.8 & 154.0 & 172.2 & 169.0 & 177.4 & 172.2 \\
\hline N47-N48-N49-Ni & 175.5 & 170.8 & 168.2 & 163.7 & 165.3 & 160.2 \\
\hline N2-N3-N4-C1 & 0.7 & 1.3 & 0.7 & 0.8 & 0.2 & 0.3 \\
\hline N47-N48-N49-C46 & 0.6 & 0.7 & 0.3 & 0.6 & 0.9 & 1.5 \\
\hline \multicolumn{7}{|l|}{ NBO Charges (e) } \\
\hline $\mathrm{Ni}$ & 0.717 & 0.718 & 0.723 & 0.725 & 0.704 & 0.707 \\
\hline N3 & -0.109 & -0.108 & -0.081 & -0.079 & -0.103 & -0.105 \\
\hline N48 & -0.104 & -0.102 & -0.080 & -0.077 & -0.100 & -0.101 \\
\hline $\mathrm{Cl} 192$ & -0.593 & -0.605 & -0.570 & -0.575 & -0.581 & -0.593 \\
\hline $\mathrm{Cl} 93$ & -0.631 & -0.625 & -0.619 & -0.619 & -0.632 & -0.629 \\
\hline O94 & -0.944 & -0.944 & -0.945 & -0.945 & -0.943 & -0.593 \\
\hline O96 & -0.945 & -0.947 & -0.945 & -0.945 & -0.944 & -0.629 \\
\hline
\end{tabular}


After optimization of the proposed structures at DFT level $[64,65]$ for the different ligands and Ni (II) complexes, it is shown that the nickel complexes adopt an octahedral geometry Fig. 5. Selected bands lengths, distances, bond angles and dihedral angles for the different ligands and their nickel complexes are summarized in Table 6. As it is mentioned, all complexes adopt an octahedral geometry formed by two ligands acting as monodentate through nitrogen atoms (N3), two Chloride atoms (C192, C193) and two molecules of coordinated water (O94, O96).

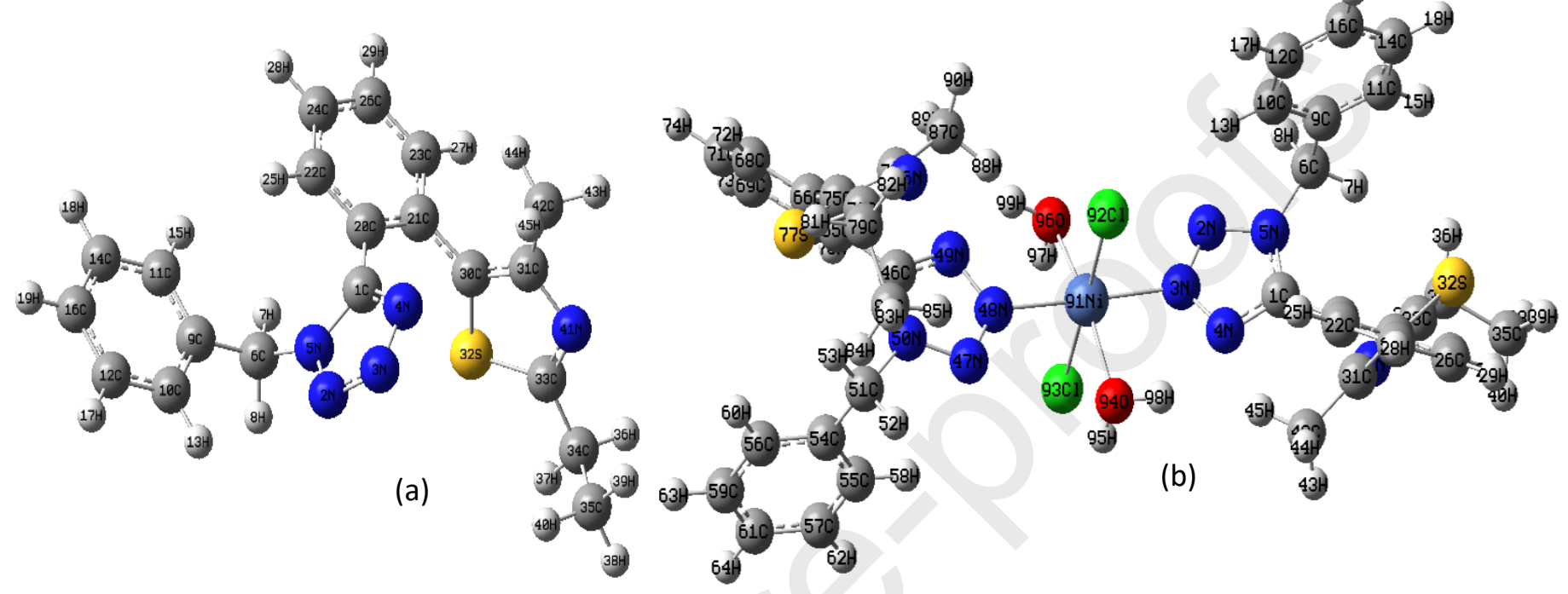

Fig. 5.Optimized structures of $\mathrm{L}^{1}$ ligand (a) and $\mathrm{Ni}-\mathrm{L}^{1}$ complex(b).

In the free ligands, the bonds distances between 1.314-1.332 $\AA$ and $1.395-1.409 \AA$ ranges correspond to N3-N2 double bonds and N3-N4 simple bonds, respectively for all the ligands. It is noted that these bonds are become shorter by $0.008-0.011 \AA$ and $0.006-0.011 \AA$ for N3-N2 and N3N4 respectively, upon complexation. It is also noted that the two Chloride atoms $(\mathrm{C192}, \mathrm{C193})$ and the two aqua $(\mathrm{O} 94, \mathrm{O} 96)$ are in trans position with a band angels of $177.9^{\circ}-179.7^{\circ}$ and $163.9^{\circ}$ $165.7^{\circ}$ respectively. The bond lengths of Ni-O94 which are in the ranges $2.093-2.102 \AA$ seen shorter than Ni-O96 bonds lengths by 0.003-0.008 $\AA$ for all complexes, while the Ni-C192 bond lengths are shorter than Ni-C193 by $0.0061-0.111 \AA$. Bond angles N3-Ni-N48 are in the range $172.7^{\circ}-76.7^{\circ}$ for all $\mathrm{Ni}(\mathrm{II})$ complexes. The N2-N3-N4-Ni and N47-N48-N49-Ni dihedral angles are in the range $154.0^{\circ}-177.4^{\circ}$ and $160.2^{\circ}-175.5^{\circ}$ respectively, which leads to deduct that the ligands are bonded into the metal ion in trans position. These results indicate a distorted octahedral geometry around the metal center [66].

\subsubsection{NBO charges}

In order to understand the site of electrophilic and nucleophilic attack [67], the natural bond orbital (NBO) analysis for each atom of the different complexes and their ligands were carried out. According to the calculated atomic charges presented in Table 6, the valence of nickel in its 
complexes is +2 , while the net charge of this metal for all complexes is between $0.704-0.725 \mathrm{e}$ range. The decrease of the net charge of N3 atoms by $0.044-0.054 \mathrm{e}$ for the different ligands reveals the participation of electrons from ligands donor atoms to metallic ions and shows a covalent character of metal-ligand bands, which decrease in the following order: Ni-L $\mathrm{L}^{5}>\mathrm{Ni}-\mathrm{L}^{6}>\mathrm{Ni}-\mathrm{L}^{1}>\mathrm{Ni}-$ $\mathrm{L}^{2}>\mathrm{Ni}-\mathrm{L}^{3}>\mathrm{Ni}-\mathrm{L}^{4}$.

\subsubsection{Frontier molecular orbitals}

The frontier molecular orbitals are important parameters and play role in understanding the chemical reactions and stability [68]. The HOMO (Highest occupied Molecular Orbital) presents the electron donating ability and the higher energy value $\mathrm{E}_{\mathrm{HO} о}$ corresponds to the greater electron donating [69]. The LUMO (Lowest unoccupied Molecular Orbital) presents the ability of a molecule for receiving electrons and the lower energy value $\mathrm{E}_{\mathrm{LUMO}}$ corresponds to the smaller resistance to accept electrons [70]. LUMO-HOMO energy gap $(\Delta \mathrm{E})$ is an important parameter that helps to understand the biological activity of molecules [71]. The HOMO, LUMO and $\Delta \mathrm{E}$ energy gap of the ligands and nickel (II) complexes are grouped in Table 7 and schematized in Fig. 6 and Fig. 7.

Table 7. Energy properties of the ligands and their complexes.

\begin{tabular}{lllllll}
\hline Parameters & $\mathrm{L}^{1}$ & $\mathrm{~L}^{2}$ & $\mathrm{~L}^{3}$ & $\mathrm{~L}^{4}$ & $\mathrm{~L}^{5}$ & $\mathrm{~L}^{6}$ \\
\hline HOMO $(\mathrm{eV})$ & -6.588 & -5.939 & -6.511 & -5.810 & -6.637 & -5.986 \\
LUMO $(\mathrm{eV})$ & -1.782 & -1.458 & -2.563 & -2.490 & -1.844 & -1.510 \\
Gap $(\mathrm{eV})$ & 4.806 & 4.481 & 3.948 & 3.320 & 4.793 & 4.476 \\
\hline Parameters & $\mathrm{Ni}-\mathrm{L}^{1}$ & $\mathrm{Ni}-\mathrm{L}^{2}$ & $\mathrm{Ni}-\mathrm{L}^{3}$ & $\mathrm{Ni}-\mathrm{L}^{4}$ & $\mathrm{Ni}-\mathrm{L}^{5}$ & $\mathrm{Ni}-\mathrm{L}^{6}$ \\
\hline HOMO $(\mathrm{eV})$ & -5.462 & -5.324 & -5.279 & -5.128 & -5.719 & -5.539 \\
LUMO $(\mathrm{eV})$ & -1.664 & -1.942 & -2.807 & -2.702 & -1.589 & -1.786 \\
$\Delta \mathrm{E}(\mathrm{eV})$ & 3.798 & 3.382 & 2.472 & 2.426 & 4.130 & 3.753 \\
\hline
\end{tabular}

In the free ligands the HOMO is located on [2-(2-ethyl-4-methylthiazol) phenyl] and [2-(1-methyl pyrrol-2-yl) phenyl] groups, While the LUMO is located on [2-(2-ethyl-4-methylthiazol) phenyl], [2-(1-methyl pyrrol-2-yl) phenyl] groups and also on the tetrazole group. The LUMO is more extended on the ligands than the HOMO. For the nickel complexes, the HOMO density is essentially located on the metal and chloride ions. The LUMO density covers almost the two ligands in $\mathrm{L}^{3}$ and $\mathrm{L}^{4}$ complexes and it is situated around only one ligand for the rest of the 
complexes. The energy gaps $(\Delta \mathrm{E})$ of $\mathrm{L}^{3}$ and $\mathrm{L}^{4}$ complexes are the smallest suggesting a lower stability and a higher antimicrobial activity for these two complexes than the rest of the complexes [38].
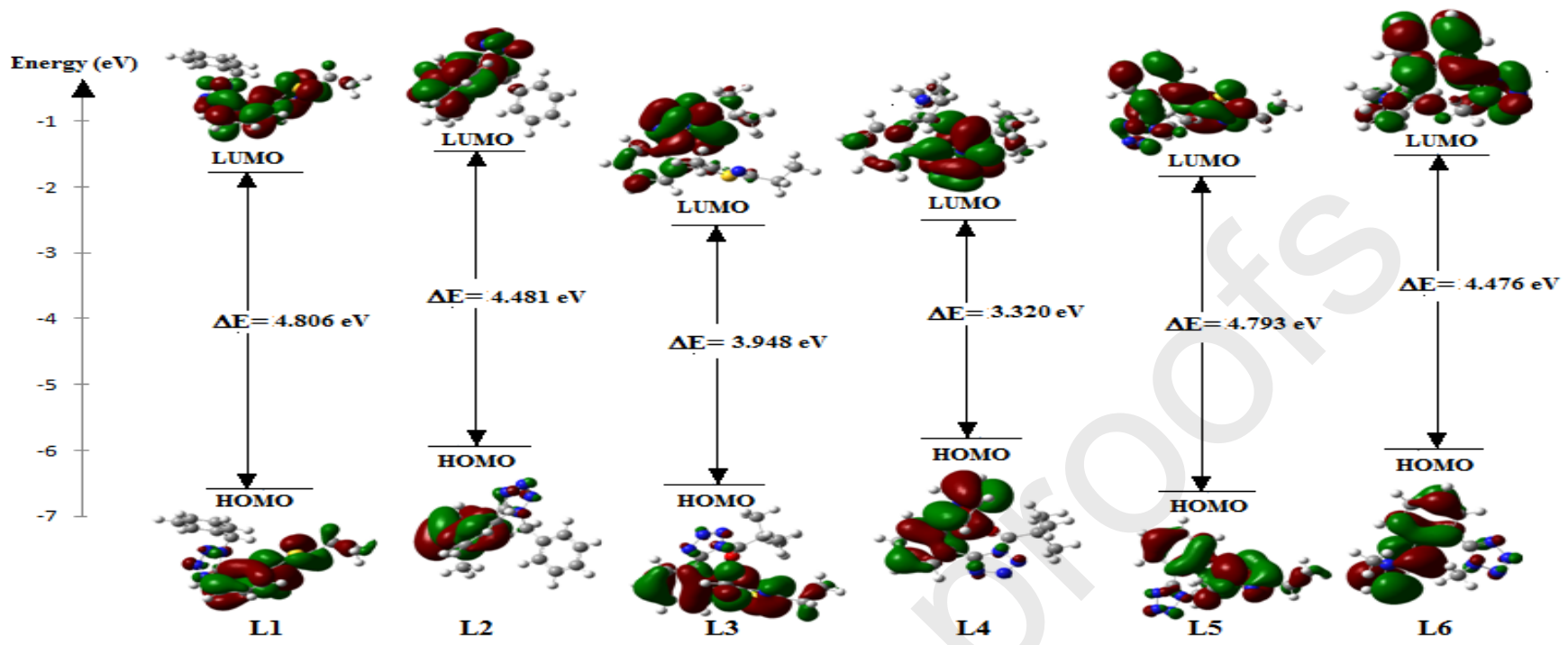

Fig. 6. Energy levels of the HOMO, LUMO and energy gap for the free ligands.
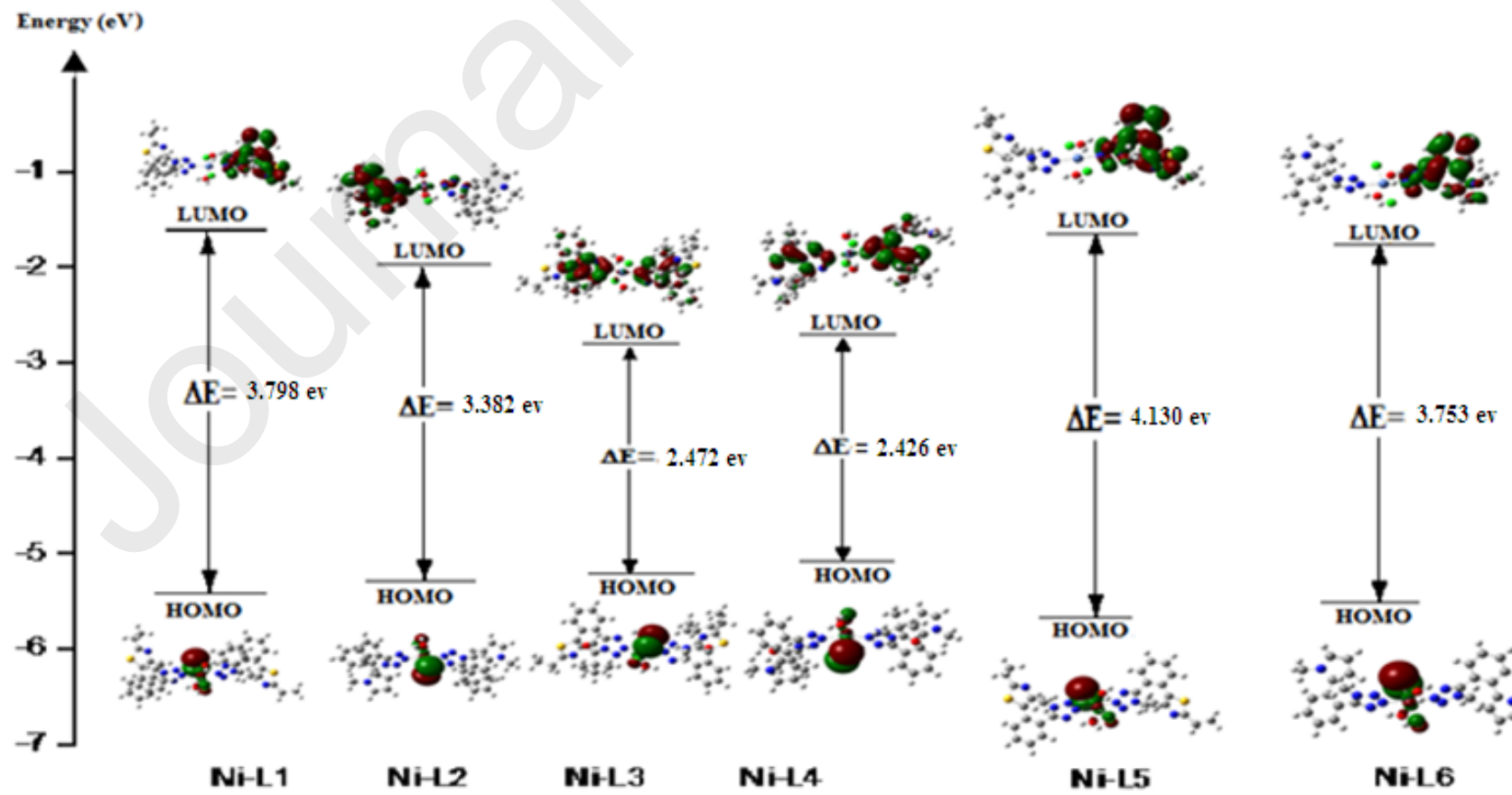

$\mathrm{NiH2}$

Ni-L3

$\mathrm{NiH4}$

Ni-15

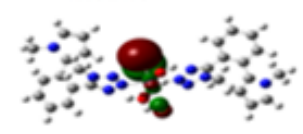

Ni-L6

Fig. 7. Energy levels of the HOMO, LUMO and energy gap for the synthesized complexes. 


\subsubsection{Complexes stability}

The binding energy $\mathrm{E}_{\text {binding }}$ is estimated by the difference between the optimized complex energy $\left(\mathrm{E}_{\text {complex }}\right)$ and the sum of the isolated metal salt $\left(\mathrm{MCl}_{2}\right)$ energy $\left(\mathrm{E}_{\mathrm{MCl} 2}\right)$ and the isolated ligand energy ( $\left.E_{\text {ligand }}\right)[66]$. The calculation of the binding energies $E_{\text {binding }}$ for the synthesized complexes allow to compare the stability of these complexes. The binding energy $\mathrm{E}_{\text {binding }}$ of the obtained structures are presented in Table 8 and performed as follows:

$\mathrm{E}_{\text {binding }}=\mathrm{E}_{\text {complex }}-\left(\mathrm{E}_{\mathrm{MCl} 2}+\mathrm{E}_{\text {ligand }}\right)$

As can be observed from Table8, the order of the binding energies of the synthesized complexes is as follows: $\mathrm{Ni}-\mathrm{L}^{4}<\mathrm{Ni}-\mathrm{L}^{3}<\mathrm{Ni}-\mathrm{L}^{2}<\mathrm{Ni}-\mathrm{L}^{1}<\mathrm{Ni}-\mathrm{L}^{6}<\mathrm{Ni}-\mathrm{L}^{5}$

Table 8. Binding energies of the complexes obtained at DFT level.

\begin{tabular}{cc}
\hline Complexes & $\mathrm{E}_{\text {binding }}(\mathrm{Kcal} / \mathrm{mol})$ \\
\hline Ni-L & -120.084 \\
Ni-L & -120.023 \\
Ni-L & -117.577 \\
Ni-L & -117.540 \\
Ni-L & -123.466 \\
Ni-L & -122.873 \\
\hline
\end{tabular}

\subsection{Electrochemical study}

The cyclic voltammetry was carried out, in DMSO solutions, in the potential range -2.5 to $2.5 \mathrm{~V}$ and at room temperature, in order to evaluate the redox properties of the ligands and their nickel (II) complexes and to understand the electronic effect of the substituents on these properties. The redox potentials at sweep rate $0.1 \mathrm{~V} . \mathrm{S}^{-1}$ are collected in Table 9 for the ligands and those for the nickel (II) complexes are summarized in Table 10.

\subsubsection{Redox properties of the ligands}

The position 1 in $\mathrm{L}^{1}$ and $\mathrm{L}^{2}$ ligands is occupied by the benzyl (-CH2-Ph) group. In $\mathrm{L}^{3}$ and $\mathrm{L}^{4}$ ligands this position is occupied by the pivaloyl (tBu-CO-) group. The methyl (-CH3) group is in position 1 in $\mathrm{L}^{5}$ and $\mathrm{L}^{6}$ ligands. The position 5 in $\mathrm{L}^{1}, \mathrm{~L}^{3}$ and $\mathrm{L}^{5}$ ligands is occupied by [2-(2-ethyl-4methylthiazol) phenyl] group. In $\mathrm{L}^{2}, \mathrm{~L}^{4}$ and $\mathrm{L}^{6}$ ligands the group [2-(1-methyl pyrrol-2-yl) phenyl] is in position 5 (scheme 1). 
Each ligand exhibits two irreversible reduction processes and one irreversible oxidation Fig. 8.

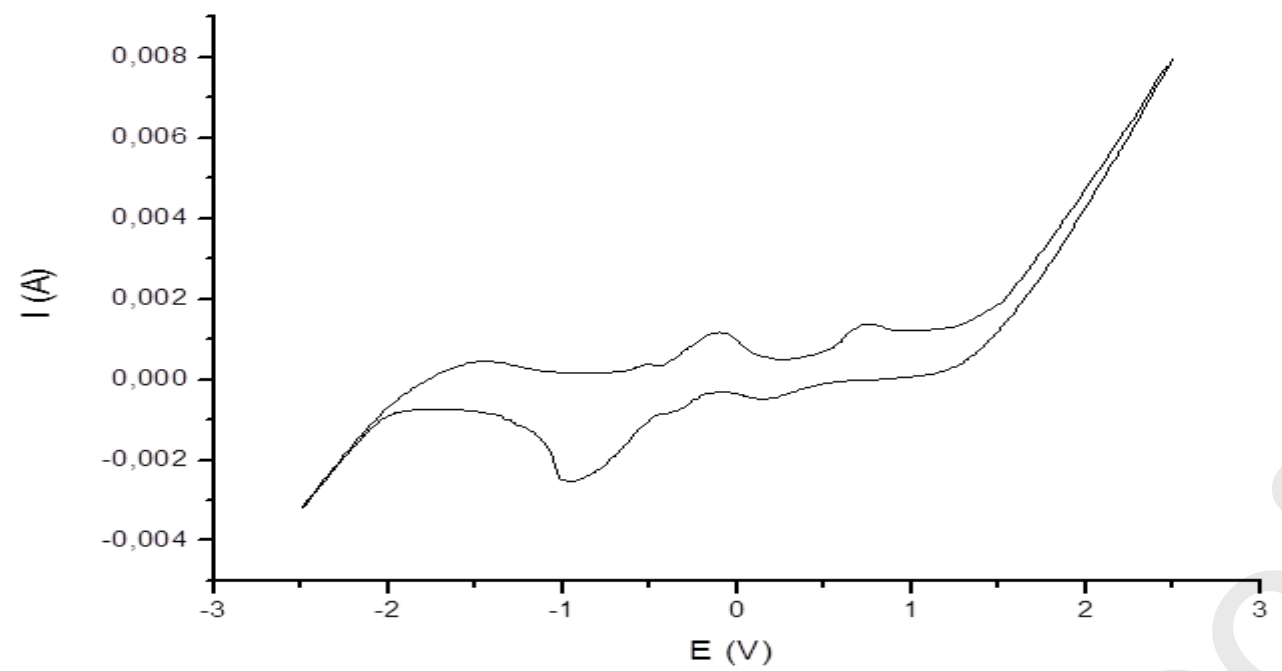

Fig. 8. Cyclic voltammogram of $\mathrm{L}^{5}$ ligand at $10^{-3} \mathrm{M}$ in DMSO $\left(100 \mathrm{mV} \cdot \mathrm{S}^{-1}\right)$.

At potentials ranging from -0.87 to $-0.98 \mathrm{~V}$, one cathodic wave is observed for all ligands and corresponds to an irreversible reduction process attributed to the tetrazole group [72]. The second reduction is seen at the potential range -0.28 to $-0.35 \mathrm{~V}$ and can be assigned to the reduction of the thiazole group in $\mathrm{L}^{1}$ and $\mathrm{L}^{5}$ ligands [73], of the pyrrol group in $\mathrm{L}^{2}$ and $\mathrm{L}^{6}$ ligands and of the pivaloyl group in $\mathrm{L}^{3}$ and $\mathrm{L}^{4}$ ligands. These results are in perfect agreement with the distribution of the LUMO that appears in $\mathrm{L}^{1}, \mathrm{~L}^{2}, \mathrm{~L}^{5}$ and $\mathrm{L}^{6}$ over the tetrazole, [2-(2-ethyl-4-methylthiazol) phenyl] group and [2-(1-methyl pyrrol-2-yl) phenyl] groups. $\mathrm{In}^{3}$ and $\mathrm{L}^{4}$ ligands the LUMO is located also on the tetrazole and the pivaloyl groups (Fig. 6).

It is noted from Table 9 that the first observed reduction potential of the tetrazole group in the ligands is affected by the substituents in position 1 and 5 . The reduction potential of the tetrazole group in $\mathrm{L}^{5}$ ligand is more negative than in $\mathrm{L}^{1}$ and $\mathrm{L}^{3}$ ligands. The potential of this group in $\mathrm{L}^{6}$ ligand is more negative than in $\mathrm{L}^{2}$ and $\mathrm{L}^{4}$ ligands. These results are attributed to the electronic effect of the different substituents (methyl, benzyl and pivaloyl) located in position 1 . The high electron donor effect of the methyl group carried by $\mathrm{L}^{5}$ and $\mathrm{L}^{6}$ ligands moves the reduction potentials of the tetrazole group towards more negative values [74]. It is also noted that the potentials of the reduction process of the tetrazole group in $\mathrm{L}^{1}, \mathrm{~L}^{3}$ and $\mathrm{L}^{5}$ ligands are more negative when the tetrazole group is in $\mathrm{L}^{2}, \mathrm{~L}^{4}$ and $\mathrm{L}^{6}$ ligands. This is also attributed to the various electronic effect of ([2- (2-ethyl-4-methylthiazole) phenyl] and [2- (1-methylpyrrol-2-yl) phenyl]) substituents of the located in position 5. The electron withdrawing effect of [2- (2-ethyl-4-methylthiazole) phenyl] group carried by $\mathrm{L}^{1}, \mathrm{~L}^{3}$ and $\mathrm{L}^{5}$ ligands is smaller than [2- (1-methylpyrrol-2-yl) phenyl] group carried by $\mathrm{L}^{2}, \mathrm{~L}^{4}$ and $\mathrm{L}^{6}$ ligands. These results reveal that the reduction process of the tetrazole 
group is more difficult in $\mathrm{L}^{1}, \mathrm{~L}^{3}$ and $\mathrm{L}^{5}$ ligands than in $\mathrm{L}^{2}, \mathrm{~L}^{4}$ and $\mathrm{L}^{6}$ ligands and it is the hardest in L5 and L6 ligands [57].

About the second reduction potential showed by the cyclic voltammogram of each ligand, it is noted that the reduction potential of the thiazole group in $\mathrm{L}^{5}$ ligand is more negative than when it is in $\mathrm{L}^{1}$ ligand. The reduction potential of the pyrrol group in $\mathrm{L}^{6}$ ligand is more negative than when it is in $\mathrm{L}^{2}$ ligand. The shift of the reduction potentials towards the negative values is attributed to the electronic effect of the benzyl substituent located in position 1 of $\mathrm{L}^{1}$ and $\mathrm{L}^{2}$ ligands and the methyl substituents located in position 1 of $\mathrm{L}^{5}$ and $\mathrm{L}^{6}$ ligands [75]. The benzyl group has an electron withdrawing effect, whereas the methyl group presents an electron donating effect. Thus, the electron donating effect moves the reduction potentials of the thiazole and pyrrol groups in $\mathrm{L}^{5}$ and $\mathrm{L}^{6}$ ligands towards negative values. These results revealed that the reduction processes of the thiazole group in $\mathrm{L}^{5}$ ligand and the pyrrol group in $\mathrm{L}^{6}$ ligand are more difficult than in $\mathrm{L}^{1}$ and $\mathrm{L}^{2}$ ligands, respectively. The reduction potential of the pivaloyl group carried by $\mathrm{L}^{3}$ ligand is more negative than when it is carried by $\mathrm{L}^{4}$ ligand. This could be explained by the different electron withdrawing effect of the [2- (2-ethyl-4-methylthiazole) phenyl] and [2- (1-methylpyrrol-2-yl) phenyl] groups located in position 5 in L3 and L ${ }^{4}$ ligands, respectively. The electronic effect of [2- (2-ethyl-4-methylthiazole) phenyl] group is smaller than the electronic effect of [2- (1-methylpyrrol-2-yl) phenyl] group. Therefore, the reduction process of the pivaloyl group in $\mathrm{L}^{3}$ ligand is more difficult than in $\mathrm{L}^{4}$ ligand.

Table 9. Redox potentials of the ligands.

\begin{tabular}{lccc|lcc}
\hline Compounds & \multicolumn{3}{l}{ Reduction } & \multicolumn{3}{l}{ Oxidation } \\
\cline { 2 - 7 } & \multicolumn{7}{c}{$\mathrm{E}_{\mathrm{Pc}}(\mathrm{V}) \mathrm{E}_{\mathrm{Pa}}(\mathrm{V})$} & \multicolumn{2}{l}{$\mathrm{E}(\mathrm{V}) \mathrm{E}_{\mathrm{Pa}}(\mathrm{V}) \mathrm{E}_{\mathrm{Pc}}(\mathrm{V}) \Delta \mathrm{E}(\mathrm{V})$} \\
\hline $\mathrm{L}^{1}$ & -0.92 & -0.46 & 0.46 & +0.88 & +0.18 & 0.69 \\
& -0.32 & -0.12 & 0.20 & & & \\
\hline $\mathrm{L}^{2}$ & -0.91 & -0.48 & 0.41 & +0.51 & +0.13 & 0.38 \\
& -0.31 & -0.12 & 0.18 & & & \\
\hline $\mathrm{L}^{3}$ & -0.88 & -0.44 & 0.44 & +0.97 & +0.15 & 0.82 \\
& -0.31 & -0.11 & 0.2 & & & \\
\hline $\mathrm{L}^{4}$ & -0.87 & -0.50 & 0.37 & +0.56 & +0.14 & 0.42 \\
& -0.28 & -0.12 & 0.16 & & & \\
\hline $\mathrm{L}^{5}$ & -0.98 & -0.51 & 0.47 & +0.74 & +0.14 & 0.59 \\
& -0.35 & -0.09 & 0.25 & & & \\
\hline $\mathrm{L}^{6}$ & -0.93 & -0.53 & 0.39 & +0.46 & +0.18 & 0.28 \\
& -0.33 & -0.15 & 0.18 & & & \\
\hline
\end{tabular}


From +0.46 to $+0.97 \mathrm{~V}$ potential range, one anodic peak is showed and attributed to an irreversible oxidation of the thiazole groups in $\mathrm{L}^{1}, \mathrm{~L}^{3}$ and $\mathrm{L}^{5}$ ligands and of the pyrrol groups in $\mathrm{L}^{2}, \mathrm{~L}^{4}$ and $\mathrm{L}^{6}$ ligands [76]. The attribution of the oxidation process is supported by the frontier orbital HOMO which is distributed around the [2- (2-ethyl-4-methylthiazole) phenyl] and the [2- (1-methylpyrrol2-yl) phenyl] groups in ligands (Fig. 6).

About the irreversible oxidation exhibited by each ligand, it is noted from the results given in Table 9 that the oxidation potential of the thiazole group in $\mathrm{L}^{3}$ ligand is more positive than when in $\mathrm{L}^{1}$ and $\mathrm{L}^{5}$ ligands. The oxidation potential of the pyrrol group in $\mathrm{L}^{4}$ ligand is more positive than when in $\mathrm{L}^{2}$ and $\mathrm{L}^{6}$ ligands. The anodic shift of the oxidation potential of the thiazole group in $\mathrm{L}^{3}$ ligand and pyrrol group in $\mathrm{L}^{4}$ ligand is due to the highest electron withdrawing effect of the pivaloyl group located in position 1 of these ligands [77]. These results indicate that the oxidation processes in $\mathrm{L}^{3}$ and $\mathrm{L}^{4}$ ligands are easier than in the other ligands [78]. It can be also concluded from Table 9 that the oxidation process of the thiazole group in $\mathrm{L}^{1}, \mathrm{~L}^{3}$ and $\mathrm{L}^{5}$ ligands is easier than the oxidation process of the pyrrol group in $\mathrm{L}^{2}, \mathrm{~L}^{4}$ and $\mathrm{L}^{6}$ ligands.

\subsubsection{Redox properties of the nickel (II) complexes}

The cyclic voltammogram of $\mathrm{Ni} \mathrm{Cl}_{2} \cdot 6 \mathrm{H}_{2} \mathrm{O}$ compound presents a cathodic potential $\mathrm{E}_{\mathrm{Pc}}$ at $-1.4 \mathrm{~V}$ and its associated anodic peak $\mathrm{E}_{\mathrm{pa}}$ at $-0.7 \mathrm{~V}$.

The redox properties of the nickel (II) complexes were also studied by cyclic voltammetry and the potential values are collected in Table 10. The cyclic voltammogram of the complexes showed the redox processes observed for the free ligands and an addition cathodic peak appeared at the potential range going from -1.42 to $-1.48 \mathrm{~V}$ (Fig S4, Supplementary material). By comparing the cyclic voltammogram of the complexes with those of the free ligands and that of $\mathrm{Ni} \mathrm{Cl}_{2} \cdot 6 \mathrm{H}_{2} \mathrm{O}$ taken as reference, the additional cathodic process could be attributed to the reduction of $\mathrm{Ni}$ (II) to $\mathrm{Ni}(\mathrm{I})$ [79].

It is observed from Table 10 that the reduction potential of $\mathrm{Ni}$ (II/I) couple in the complexes is affected by the complexation and shifted to more negative potentials. The LUMOs of the complexes are distributed around the ligands, whereas the HOMOs are concentrated around the metal center. 
Table 10. Redox potentials of the nickel complexes.

\begin{tabular}{|c|c|c|c|c|c|c|}
\hline \multirow[t]{2}{*}{ Compounds } & \multicolumn{3}{|c|}{ Reduction } & \multicolumn{3}{|c|}{ Oxidation } \\
\hline & $\mathrm{E}_{\mathrm{Pc}}(\mathrm{V})$ & $\mathrm{E}_{\mathrm{Pa}}(\mathrm{V})$ & $\Delta \mathrm{E}(\mathrm{V})$ & $\mathrm{E}_{\mathrm{Pa}}(\mathrm{V})$ & $\mathrm{E}_{\mathrm{Pc}}(\mathrm{V})$ & $\Delta \mathrm{E}(\mathrm{V})$ \\
\hline & -1.45 & -0.75 & 0.71 & & & \\
\hline \multirow[t]{3}{*}{$\mathrm{Ni}-\mathrm{L}^{1}$} & -0.89 & -0.51 & 0.38 & +0.87 & +0.16 & 0.71 \\
\hline & -0.31 & -0.14 & 0.17 & & & \\
\hline & -1.44 & -0.73 & 0.70 & & & \\
\hline \multirow[t]{3}{*}{$\mathrm{Ni}-\mathrm{L}^{2}$} & -0.88 & -0.51 & 0.36 & +0.59 & +0.12 & 0.47 \\
\hline & -0.28 & -0.16 & 0.12 & & & \\
\hline & -1.43 & -0.73 & 0.71 & & & \\
\hline \multirow[t]{3}{*}{$\mathrm{Ni}-\mathrm{L}^{3}$} & -0.86 & -0.53 & 0.33 & +0.93 & +0.26 & 0.67 \\
\hline & -0.31 & -0.13 & 0.16 & & & \\
\hline & -1.42 & -0.72 & 0.71 & & & \\
\hline \multirow[t]{3}{*}{$\mathrm{Ni}-\mathrm{L}^{4}$} & -0.85 & -0.53 & 0.32 & +0.54 & +0.15 & 0.39 \\
\hline & -0.27 & -0.15 & 0.12 & & & \\
\hline & -1.48 & -0.79 & 0.69 & & & \\
\hline \multirow[t]{3}{*}{$\mathrm{Ni}-\mathrm{L}^{5}$} & -0.94 & -0.52 & 0.41 & +0.69 & +0.11 & 0.59 \\
\hline & -0.34 & -0.09 & 0.24 & & & \\
\hline & -1.46 & -0.76 & 0.71 & & & \\
\hline \multirow[t]{2}{*}{$\mathrm{Ni}-\mathrm{L}^{6}$} & -0.91 & -0.54 & 0.36 & +0.44 & +0.15 & 0.29 \\
\hline & -0.32 & -0.11 & 0.21 & & & \\
\hline
\end{tabular}

It is noted that the reduction potential of $\mathrm{Ni}$ (II/I) couple in the complexes is sensitive to the electronic effect of the different substituents located on the coordinated ligands. Going from the lowest electron-donating effect of pivaloyl to the highest one of methyl, the electron density on nickel ion increases, the difficulty to reduce the metal center increases and the reduction potential of $\mathrm{Ni}(\mathrm{II} / \mathrm{I})$ couple shifts cathodically $[80,81]$.

It is noted from Table 10 that the cathodic peaks of the ligands when coordinated were affected by the complexation and shifted towards positive potentials. It is noted also that the oxidation potential of the ligands in the complexes moves to more negative potentials.

The complexation makes the reduction processes of the coordinated ligands easier and the oxidation processes of the coordinated ligands more difficult. While the reduction process of nickel (II) ion is more difficult in the complex than in $\mathrm{Ni} \mathrm{Cl}_{2} \cdot \mathrm{H}_{2} \mathrm{O}$ salt $[82,83]$. 


\subsection{Biological study}

\subsubsection{Antimicrobial study}

The in vitro antibacterial and antifungal activities of $\mathrm{L}^{1}-\mathrm{L}^{6}$ ligands and their nickel (II) complexes were evaluated by agar-well diffusion method [84]. The tested compounds were dissolved in Dimethyl Sulfoxide (DMSO) at two concentrations 10 and $5 \mathrm{mg} / \mathrm{ml}$.

$\mathrm{L}^{1}$ and $\mathrm{L}^{2}$ ligands have the benzyl substituent in position $1 . \mathrm{L}^{3}$ and $\mathrm{L}^{4}$ ligands carry in the same position the pivaloyl group. $\mathrm{L}^{5}$ and $\mathrm{L}^{6}$ ligands have the same substituent methyl in position $1 . \mathrm{L}^{1}, \mathrm{~L}^{3}$ and $\mathrm{L}^{5}$ ligands carry [2-(2-ethyl-4-methylthiazol) phenyl] in position 5 . This position is occupied by [2-(1-methyl pyrrol-2-yl) phenyl] in $\mathrm{L}^{2}, \mathrm{~L}^{4}$ and $\mathrm{L}^{6}$ ligands (scheme 1).

\subsubsection{Antibacterial study}

$\mathrm{L}^{1}-\mathrm{L}^{6}$ ligands and their nickel (II) complexes were evaluated for their in vitro antibacterial activity and the susceptibility inhibition zones of the ligands and their complexes were measured in diameter $(\mathrm{mm})$ and reported in Fig.9. All compounds were tested against two Gram-negative (Echerichia Coli, Klebsiella pneumoniae) and two Gram-positive (Staphylococcus aureus, Streptocoque D) bacterial strains. The obtained results were compared with that of the standard drugs (CTX: Cefotaxime for Gram-negative bacteria, GEN: Gentamicine for Gram-positive bacteria).

The results depicted in Fig.9 revealed that most ligands displayed antibacterial activities against Gram-positive bacteria rather than Gram-negative bacteria. This behavior is related to the cell wall structure of the bacteria. The cell wall is essential to the survival of bacteria. According to the literature Gram-negative bacteria present a thin cell wall consisting of a few layers of peptidoglycan surrounded by a second lipid membrane containing lipopolysaccharides and lipoproteins, but in contrast the Gram-positive bacteria have a relative thick cell wall containing many layers of peptidoglycan and teichoic acid [85].

Further, we notice that the different activities of the ligands are clearly related to the different substituents located in position 1 and 5 of the ligands and their electronic parameters $[86,30]$. 


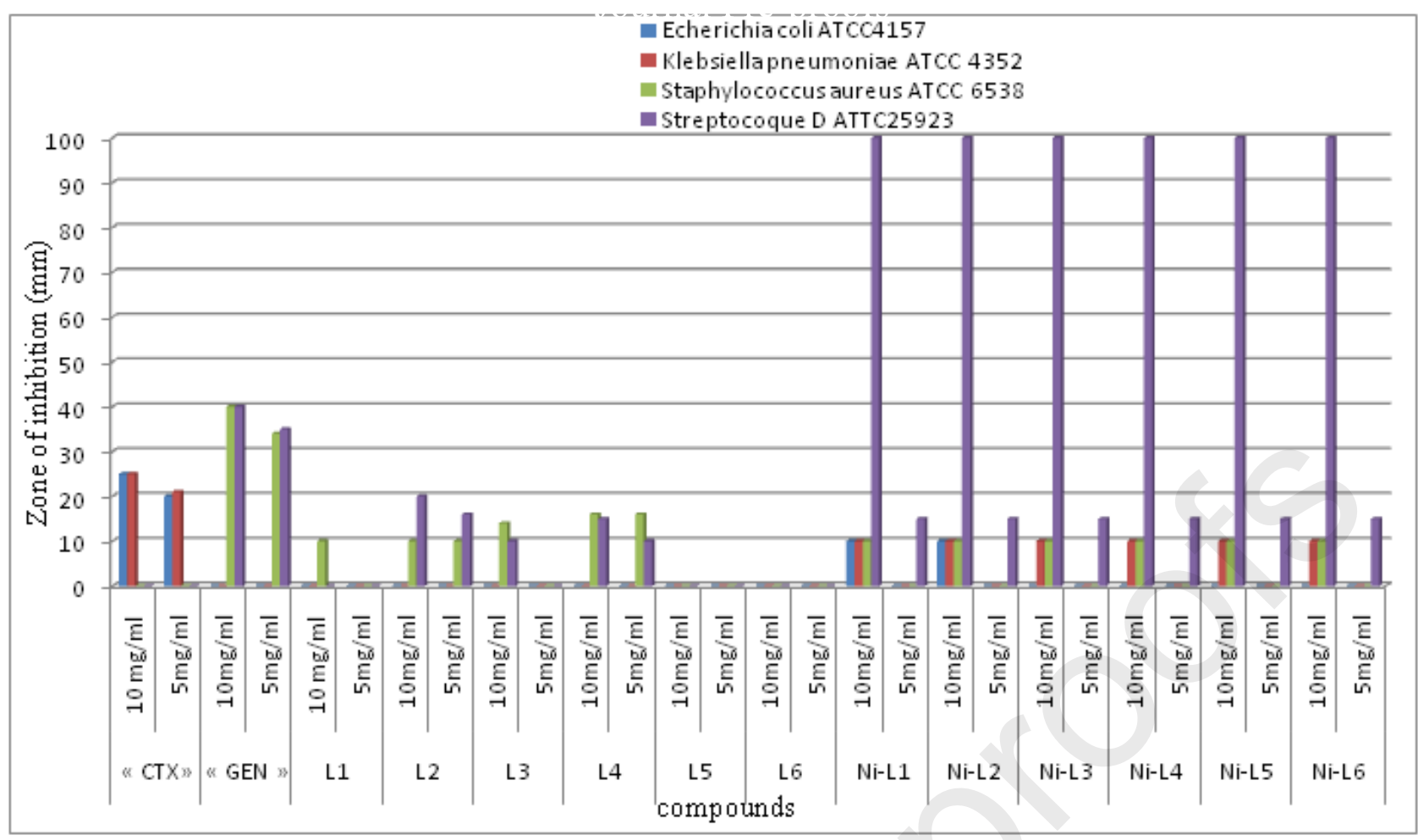

Fig. 9. Values of inhibition zone diameter $(\mathrm{nm})$ obtained by tetrazole derivatives and their nickel (II) complexes against bacterial strains

According to the results obtained, $\mathrm{L}^{1}$ exhibited a sensitive and selective antibacterial activity against Staphylococcus aureus with a concentration of $10 \mathrm{mg} / \mathrm{ml}$ while the antibacterial activity disappears at $5 \mathrm{mg} / \mathrm{ml}$. The ligand $\mathrm{L}^{2}$ showed a sensitive activity against Staphylococcus aureus and a very sensitive activity against Streptococcus $D$ with the two concentrations. $\mathrm{L}^{2}$ ligand is found more active than $\mathrm{L}^{1}$ ligand. This behavior could be explained by the different electron withdrawing effect of [2-(2-ethyl-4-methylthiazol) phenyl] and [2-(1-methyl pyrrol-2-yl) phenyl] substituents located in position 5 of the ligands. The electron withdrawing effect of [2-(2-ethyl-4-methylthiazol) phenyl] carried by $\mathrm{L}^{1}$ ligand is smaller than the electron withdrawing effect of [2-(1-methyl pyrrol-2-yl) phenyl] located on $\mathrm{L}^{2}$ ligand.

The ligand $\mathrm{L}^{4}$ showed sensitive activity against Staphylococcus aureus at both concentrations, whereas it was very sensitive at $10 \mathrm{mg} / \mathrm{ml}$ and sensitive to $5 \mathrm{mg} / \mathrm{ml}$ against Streptocoque D. The ligand $\mathrm{L}^{3}$ showed a sensitive activity against both of Gram-positive bacteria at $10 \mathrm{mg} / \mathrm{ml}$ and no activity at concentration $5 \mathrm{mg} / \mathrm{ml}$. $\mathrm{L}^{4}$ ligand has a better antibacterial activity than $\mathrm{L}^{3}$ ligand. The difference in the activity between $\mathrm{L}^{3}$ and $\mathrm{L}^{4}$ ligands is attributed to the different electronic withdrawing effect of [2-(2-ethyl-4-methylthiazol) phenyl] and [2-(1-methyl pyrrol-2-yl) phenyl] substituents carried by $\mathrm{L}^{3}$ and $\mathrm{L}^{4}$ ligands, respectively. The electronic withdrawing effect of [2-(1-methyl pyrrol-2-yl) phenyl] located on $\mathrm{L}^{4}$ ligand is bigger than the electronic withdrawing effect of [2-(2-ethyl-4-methylthiazol) phenyl] located on $\mathrm{L}^{3}$ ligand. 
The ligands $\mathrm{L}^{5}$ and $\mathrm{L}^{6}$ were inactive against all bacterial strains. Both of the ligands contain a moiety having an electron donor effect (-CH3) in position 1.

The ligands $\mathrm{L}^{3}$ and $\mathrm{L}^{4}$ present a higher activity than the other ligands. The electron withdrawing effect of the pivaloyl group situated in position 1 of $\mathrm{L}^{3}$ and $\mathrm{L}^{4}$ ligands increases the potency. While compounds $\mathrm{L}^{5}$ and $\mathrm{L}^{6}$ contain in position 1 the methyl group, an electron donating group, found to weaken the antibacterial activity [87]. This result could be predicted by the DFT calculations. The HOMO-LUMO energy gap values ofL 3 and $\mathrm{L}^{4}$ ligands are the lowest values (Table 7) which reflect the high antimicrobial activities of these compounds [15].

The results obtained from the in vitro antibacterial studies reveal that the synthesized complexes were more toxic against all bacterial strains compared with their free ligands. Against Staphylococcus aureus, $\mathrm{L}^{1}$ and $\mathrm{L}^{2}$ complexes showed the same activity with their parent ligands at concentration $10 \mathrm{mg} / \mathrm{ml}$ while they were inactive at concentration $5 \mathrm{mg} / \mathrm{ml}$. Also $\mathrm{L}^{3}$ and $\mathrm{L}^{4}$ complexes showed less antibacterial activity than their parent ligands. Against Echerichia coli $\mathrm{L}^{3}$, $\mathrm{L}^{4}, \mathrm{~L}^{5}$ and $\mathrm{L}^{6}$ complexes were inactive as well as their ligands at concentrations 10 and $5 \mathrm{mg} / \mathrm{ml}$.

All nickel complexes with $\mathrm{L}^{1}-\mathrm{L}^{6}$ ligands showed an extremely sensitive activity against Streptococcus group $D$ at concentration $10 \mathrm{mg} / \mathrm{ml}$ and a very sensitive activity at concentration $5 \mathrm{mg} / \mathrm{ml}$. This difference in antibacterial activity could be explained by the fact that the microorganisms have different cell wall constitution and/or the complexes might diffuse into bacterial cell membrane but stopped by a cellular mechanism [88].

The increase of the antibacterial activity of the complexes is may be due to the partial shared of the positive charge of the metal ion with the donor atoms of the coordinated ligands and possible $\pi$ electron delocalization within the whole chelate ring that is formed during coordination. Such chelation increases the lipophilic character of the central metal atom in the complex and hence increases the hydrophobic character and liposolubility of the complex favoring its penetration through the lipid layers of the cell membrane [52].

\subsubsection{Antifungal study}

The ligands $\mathrm{L}^{1}-\mathrm{L}^{6}$ and their complexes with nickel (II) were also screened for their antifungal activity against Candida albicans and Trichophyton rubrum fungal strains. The inhibition zones were measured in diameter $(\mathrm{mm})$ and presented in Fig. 10. The obtained results were compared with the stander Ketoconazole.

It was indicated from the presented results shown in Fig.10 that all the ligands were inactive against the tested organisms. Whereas nickel (II) complexes formed with these ligands were active against the tested organisms. It seems that the complexation of the ligands with nickel (II) enhance the 
Anti-fungal activity of the ligands. This could be expiained by Chelation theory [89], the polarity of metal ion would be reduced mainly because of partial sharing of its positive charge with the donor groups. Also the lipophilic nature of the metal ion increases which subsequently favors its permeation through the lipid layer of the cell membrane.

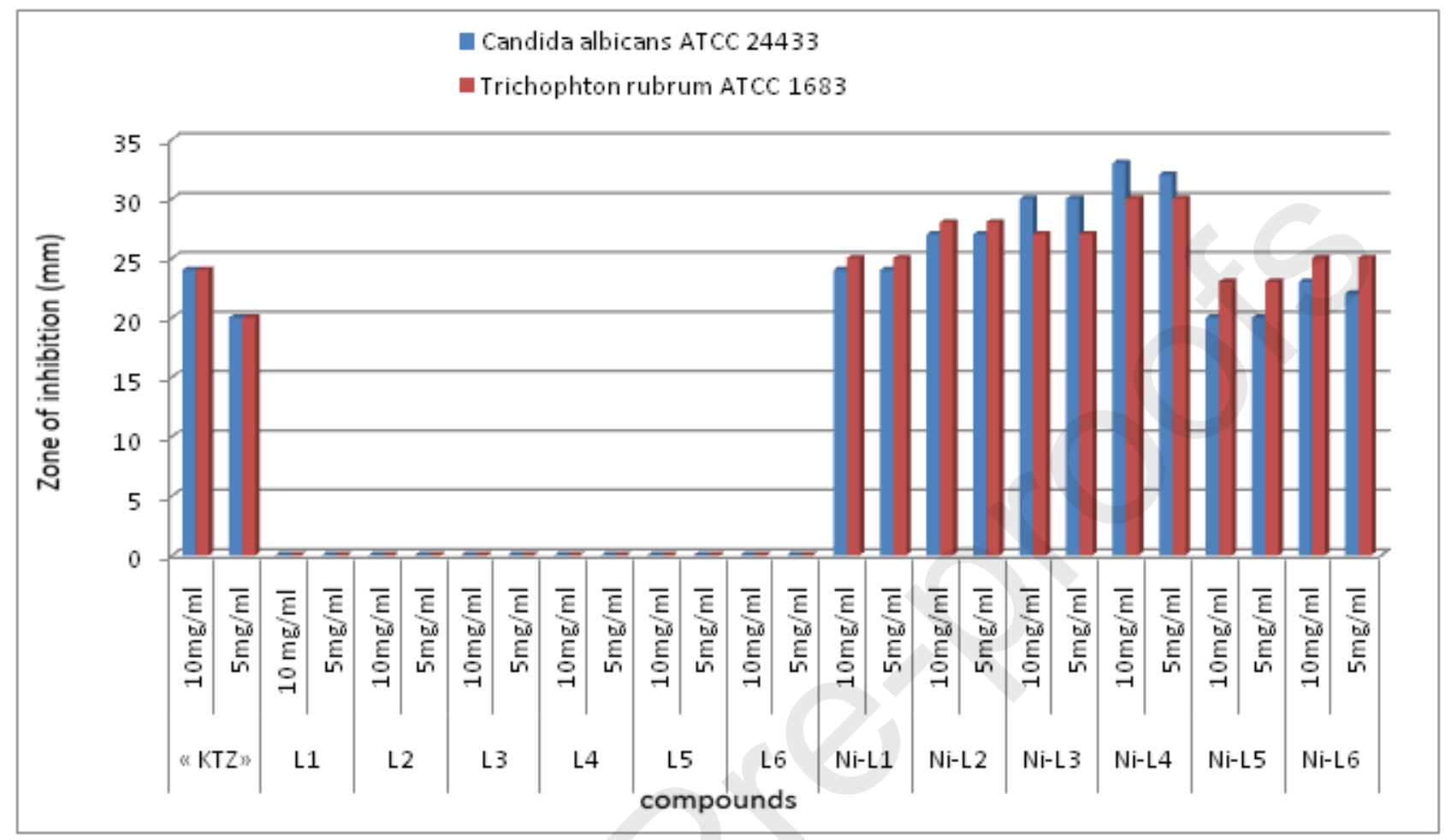

Fig.10. Values of inhibition zone diameter $(\mathrm{nm})$ obtained by tetrazole derivatives and their nickel (II) complexes against fungal strains

The difference in the activity of the complexes formed with $\mathrm{L}^{1}-\mathrm{L}^{6}$ ligands is attributed to the different electron character of the various substituents located in position 1 and 5 of the coordinated ligands.

$\mathrm{L}^{1}$ and $\mathrm{L}^{2}$ complexes showed an extremely sensitive antifungal activity against Candida albicans and Trichophyton rubrum at 10 and $5 \mathrm{mg} / \mathrm{ml}$. $\mathrm{L}^{2}$ complex exhibited a better antifungal activity than $\mathrm{L}^{1}$ complex. This could be explained by the electronic effect of the different groups located in position 5 of the coordinated ligands. [2-(2-ethyl-4-methylthiazol) phenyl] group carried by $\mathrm{L}^{1}$ complex has less electron withdrawing effect than [2-(1-methyl pyrrol-2-yl) phenyl] substituent carried by $\mathrm{L}^{2}$ complex.

$\mathrm{L}^{3}$ and $\mathrm{L}^{4}$ complexes present also an extremely sensitive antifungal activity against Candida albicans and Trichophyton rubrum at the two concentrations. $\mathrm{L}^{3}$ complex displayed less antifungal activity than $\mathrm{L}^{4}$ complex. This result is attributed to the smaller electron withdrawing effect of [2(2-ethyl-4-methylthiazol) phenyl] substituent carried by $\mathrm{L}^{3}$ complex compared with [2-(1-methyl pyrrol-2-yl) phenyl] substituent carried by $\mathrm{L}^{4}$ complex. 
At concentrations 10 and $5 \mathrm{mg} / \mathrm{ml}$, the complex with $\mathrm{L}^{6}$ ligand presented an extremely sensitive antifungal activity against Candida albicans and against Trichophyton rubrum, while $\mathrm{L}^{5}$ complex presented a very sensitive antifungal activity against the two fungal strains. This is probably due to the high electron withdrawing effect of [2-(1-methyl pyrrol-2-yl) phenyl] substituent carried by $\mathrm{L}^{6}$ complex in comparison with [2-(2-ethyl-4-methylthiazol) phenyl] substituent carried by $\mathrm{L}^{5}$ complex.

Regarding antifungal activity, $\mathrm{L}^{1}, \mathrm{~L}^{2}, \mathrm{~L}^{3}$ and $\mathrm{L}^{4}$ complexes exhibit a better activity than $\mathrm{L}^{5}$ and $\mathrm{L}^{6}$ complexes. This could be related to the presence of the electron donating effect of the methyl group located in position 1 of the $\mathrm{L}^{5}$ and $\mathrm{L}^{6}$ coordinated ligands which decreases the antifungal activity of the molecules [90].

It is worth mentioning that incorporation of substituents with electron withdrawing effect at position 1 of the coordinated ligands produced a high antimicrobial activity. Such an electronic effect decreases the electron density around the tetrazole ring, which decreases its lipophilic character which in turn deactivates the enzymes responsible for respiration processes and other essential enzymes in various metabolic pathways of the tested microbial strains [85, 91].

The antimicrobial study showed that the complexes are better active than the free ligands. This result is in perfect agreement with DFT calculations. The energy gaps $\triangle \mathrm{E}$ (HOMO-LUMO) of the complexes are smaller than those of the free ligands. This suggests a lowest kinetic stability for the complexes compared to the free ligands and reflects a better antimicrobial activity for these complexes [92]. The complexes with $\mathrm{L}^{3}$ and $\mathrm{L}^{4}$ ligands were the most active ones. They possess the lowest energy gaps $\Delta \mathrm{E}$ (HOMO-LUMO) values [93].

\subsubsection{Antioxidant study}

The antioxidant activity is none other than the ability to act as free radical scavengers, either by hydrogen or by an electron of the corresponding compounds.

Many complexes have been extensively investigated for their antioxidant properties [94]. In this study we intend to evaluate the in vitro antioxidant properties of the ligands which are tetrazole derivatives and their nickel (II) complexes on the DPPH radical, which will be expressed as ascorbic acid equivalent. The percentage of activity was calculated and presented in Table 11.

To evaluate the antioxidant property of the various compounds, the DPPH (2, 2-diphenyl-1-picrylhydrazyl) method was used. DPPH exhibits intense violet coloration due to delocalization of the free radical, characterized by an absorption band at $517 \mathrm{~nm}$ [95]. It is known that the DPPH as a free radical (DPPH) is very stable and can accept either an electron or hydrogen radical. This leads 
to recombination of the free radical of DPPH and a change of the initial color to yellow and a decrease in absorption at $517 \mathrm{~nm}[96]$.

Table 11.Antioxidant activity of the ligands and their complexes.

\begin{tabular}{lll}
\hline Compounds & Ascorbic acid Eq $(\mu \mathrm{M})$ & AA $\%$ \\
\hline $\mathrm{L}^{1}$ & 27.9 & 22.74 \\
\hline $\mathrm{L}^{2}$ & 30.1 & 25.91 \\
\hline $\mathrm{L}^{3}$ & 31.3 & 27.79 \\
\hline $\mathrm{L}^{4}$ & 31.5 & 28.20 \\
\hline $\mathrm{L}^{5}$ & 26.7 & 20.76 \\
\hline $\mathrm{L}^{6}$ & 28.7 & 23.84 \\
\hline $\mathrm{Ni}-\mathrm{L}^{1}$ & 30.8 & 27.06 \\
\hline $\mathrm{Ni}-\mathrm{L}^{2}$ & 39.8 & 40.76 \\
\hline Ni-L & 33.5 & 31.14 \\
\hline Ni-L & 41.2 & 42.28 \\
\hline Ni-L & 30.2 & 26.14 \\
\hline Ni-L & 34.9 & 33.19 \\
\hline Chlorogenic acid $^{3}$ & 10.6 & 29.78
\end{tabular}

AA: Antioxidant Activity Eq: Equivalent

No significant radical scavenging activity was observed with $\mathrm{Ni}^{2+}$ in $\mathrm{NiCl}_{2} \cdot 6 \mathrm{H}_{2} \mathrm{O}$ salt. Table 11 shows that the ligands and their complexes have a better activity compared to the reference (Chlorogenic acid). The ligands $\mathrm{L}^{2}, \mathrm{~L}^{4}$ and $\mathrm{L}^{6}$ exhibited a better antioxidant activity than $\mathrm{L}^{1}, \mathrm{~L}^{3}$ and $\mathrm{L}^{5}$ ligands. This behavior could be related to the different substituents ([2-(2-ethyl-4-methylthiazol) phenyl] and [2-(1-methyl pyrrol-2-yl) phenyl]) located in position 5 of the ligands and their electronic effect. The superior electron withdrawing character of [2-(1-methyl pyrrol-2-yl) phenyl] substituent located on $\mathrm{L}^{2}, \mathrm{~L}^{4}$ and $\mathrm{L}^{6}$ ligands could explain the high antioxidant activity of $\mathrm{L}^{2}, \mathrm{~L}^{4}$ and $\mathrm{L}^{6}$ ligands $[97,98] . \mathrm{L}^{3}$ and $\mathrm{L}^{4}$ ligands were the most active ones. This might be due to the presence of the pivaloyl group located in position 1 of $\mathrm{L}^{3}$ and $\mathrm{L}^{4}$ ligands and having the highest electron withdrawing effect. This result is in perfect agreement with the DFT calculations. The HOMO measures the electron donating ability of a compound [99]. The HOMO values of $\mathrm{L}^{3}$ and $\mathrm{L}^{4}$ ligands are respectively -6.511 and $-5.810 \mathrm{eV}$ (Table 7 ) and are higher than the HOMO values of the rest of 
the ligands. This indicates that $\mathrm{L}^{3}$ and $\mathrm{L}^{4}$ ligands are the best electron donors and consequently the best antioxidants ligands $[92,15]$.

The complexes showed a higher antioxidant activity than the free ligands. This is probably due to the coordination of DPPH to the metallic ion [100]. DFT calculations of the synthesized complexes confirm these results. Fig. 9 shows the energy levels of HOMO and LUMO for the Ni (II) complexes. The HOMO density is distributed over the metal and chloride ions while the LUMO density covers the ligands. The high HOMO energy values of $\mathrm{L}^{3}$ and $\mathrm{L}^{4}$ complexes show that these complexes are the highest electron donors and the best antioxidants.

\section{CONCLUSION}

A new series of nickel (II) complexes with new tetrazole derivatives previously synthesized, were isolated at solid state, characterized and tested as antimicrobial and antioxidant agents. Based on the results of the analytical and spectral techniques, all the ligands are coordinated to nickel (II) metal ion via nitrogen in an octahedral geometry. IR and TGA studies confirmed the presence of coordinated water in the coordination sphere. The DFT calculations established the optimized structure for nickel complexes.

The electrochemical studies of the synthesized compounds showed that the reduction and the oxidation processes are affected by the electron character of the different substituents (Benzyl, Pivaloyl and Methyl) located in position 1 and ([2-(2-ethyl-4-methylthiazol) phenyl] and [2-(1methyl pyrrol-2-yl) phenyl]) located in position 5 of the coordinated ligands. . Electron donating effect moves reduction potentials toward negative values, while electron withdrawing effect shifts cathodically reduction potentials values.

The electrochemical study revealed the $\mathrm{Ni}$ (II)/ Ni (I) reduction process, which was found to be more difficult in the presence of electron donating substituents in the coordinated ligand.

The reduction processes are more easily accomplished in the complexes than in the free ligands. The complexation makes the oxidation processes of the thiazole and pyrrol groups in the complexes more difficult.

All the synthesized compounds were screened for their antimicrobial activity by agar well-diffusion method. The presence of different substituents (Benzyl, Pivaloyl and Methyl) located in position 1 and ([2-(2-ethyl-4-methylthiazol) phenyl] and [2-(1-methyl pyrrol-2-yl) phenyl]) located in position 5 of the ligands is responsible for the observed varied antimicrobial activities. The data obtained revealed that the ligands $\mathrm{L}^{1}-\mathrm{L}^{6}$ and their nickel (II) complexes show very good antibacterial activity against Gram-positive than Gram-negative bacteria. This is related to the outer membrane composition of Gram-negative bacteria. The most important antimicrobial activities have been 
observed with 5-(2-(1-Pivalyltetrazol-5-yl) phenyl)-2-ethyl-4-methylthiazole (L $\left.{ }^{3}\right)$ and 5-(2-(1Methylpyrrol-2-yl) phenyl)-1-pivalyltetrazole (L4) ligands and their nickel (II) complexes. It is claimed that the Pivaloyl group with the highest electron withdrawing effect located in position 1 of 5-(2-(1-Pivalyltetrazol-5-yl) phenyl)-2-ethyl-4-methylthiazole $\left(\mathrm{L}^{3}\right)$ and 5-(2-(1-Methylpyrrol-2-yl) phenyl)-1-pivalyltetrazole (L4) ligands is responsible for enhancing antibacterial and antifungal activities. It is also indicated that the nickel (II) complexes showed better antimicrobial activities as compared to the parent ligands. This is attributed to the effect of the increased lipophilic character of these complexes upon complexation. The antimicrobial activity reveals also that the concentration plays a vital role in increasing the antimicrobial activity. As the concentration increases, the activity increases. Also the antifungal activity of the complexes was better as compared to their antibacterial activity.

The antioxidant activity of $\mathrm{L}^{1}-\mathrm{L}^{6}$ ligands and their nickel (II) complexes was evaluated by the DPPH method. The results from various radical scavenging assay showed that the synthesized compounds exhibited a better activity in comparison to the reference (Chlorogenic acid). Compounds with electron withdrawing effect exert the highest antioxidant activity.

The antioxidant results revealed that the nickel (II) complexes exhibited better antioxidant activity compared to the free ligands; this could be explained by the coordination of DPPH with the metallic ion.

It is concluded that $\mathrm{E}_{\mathrm{HOMO}}, \mathrm{E}_{\mathrm{LUMO}}, \mathrm{NBO}$ charge and binding energy values, given by the theoretical study, were the most significant descriptors for correlating the molecular structures of the synthesized compounds to their redox properties and biological activities.

\section{References}

[1] N. Bharti, Shailendra, S.Sharma, F. Naqvi and A. Azam, New palladium (II) complexes of 5nitrothiophene-2-carboxaldehyde thiosemicarbazones: synthesis, spectral studies and in vitro antiamoebic activity, Bioorg. Med. Chem. 11 (2003) 2923-2929.

[2]S. P. Wolf, R. T. Dean.,Fragmentationofproteinsbyfreeradicalsand ist effect on theirsusceptibilitytoenzymatichydrolysis, J. Biochem., 234 (1986) 399-403.

[3] F. R. G. Bergamini, M. A. Ferreira, R. E. F. de Paiva, A. F. Gomes, F. C. Gozzo, A. L. B. Formiga, F. C. A. Corbi, I. O. Mazali, D. A. Alves, M. Lancellottie and P. P. Corbi, RSC Advances. 2 (2012) 10372-10379.

[4] P. A. Ajibade and G. A. Kolawole, Synthesis, characterization and in vitro antiprotozoal studies of iron(III) complexes of some antimalarial drugs, J. Coord. Chem. 61 (2008) 3367-3374. 
[5] S. F. Sucena, R. E.F. Paiva, C. Abbehausen, I. B. Mattos, M. Lancellotti, A. L.B. Formiga, P. P. Corbi, Chemical, spectroscopic characterization, DFT studies and antibacterial activities in vitro of a new gold (I) complex with rimantadine, Spectrochim. Acta A. 89 (2012) 114-118.

[6] P. Heffeter, M. A. Jakupec, W. Orner, S. Wild, N. G. Keyserlingk, L. Elbling, H. Zorbas, A. Korynevska, S. Knasmuller, H. Sutterluty, M. Micksche, B. K. Keppler, W. Berger, Anticancer activity of the lanthanum compound [tris (1, 10-phenanthroline) lanthanum (III)] trithiocyanate (KP772; FFC24), Biochem. Pharmacol. 71(2006) 426-440.

[7] G.I. Koldobskii, R.B. Kharbash, 2-Substituted and 2, 5-disubstituted tetrazoles, Russ. J. Org. Chem. 39 (2003) 453-470.

[8] J. H Mohammed, Biological activities importance of tetrazole derivatives, Eur. Acad. Res. 3(2016) 12796-12804.

[9] L. V. Myzikov, A. Hrabalek, G. I. Koldobskii, Drugs in the tetrazole series, chem. Het. Compounds. 43(2007) 1-9.

[10] T. Mavromoustakos, A. Kolocouris, M. Zervou, P. Roumelioti, J. Matsoukas, R. Weisemann, An Effort To Understand the Molecular Basis of Hypertension through the Study of Conformational Analysis of Losartan and Sarmesin Using a Combination of Nuclear Magnetic Resonance Spectroscopy and Theoretical Calculations, J. Med. Chem. 42 (1999) 1714-1722.

[11] N. Mekni, A. Bakloiti, Synthesis of new 1-substituted 4-perfluoroalkyl tetrazol-5-ones, J. Fluorine Chem. 129 (2008) 1073-1075.

[12] J.H. Toney, P. M. D. Fitzgerald, N. Grover-Sharman, S. H. Olson, W. J. May, J. G. Sundelof, D. E. Venderwall, K. A. Cleary, S. K. Grant, J. K. Wu, J. W. Kozarich, D. L. Pompliano, G. G. Hammond, Antibiotic sensitization using biphenyl tetrazoles as potent inhibitors of Bacteroidesfragilismetallo- $\beta$-lactamase, Chem. Biol. 5 (1998) 185-196.

[13]V. Dhayanithi, S. S. Syed, K. Kumaran, K. R. J. Sankar, Ramaswamy V. Ragavan, P. S. K. Goud, N. S. Kumari and H. N. Pati, Synthesis of selected 5-thio-substituted tetrazole derivatives and evaluation of their antibacterial and antifungal activities, J. Serb. Chem. Soc. 76 (2011) 165 175 .

[14] Dhayanithi Varadaraji, Syed S. Suban, Venkat R. Ramasamy, Kumaran Kubendiran, Jai Sankar K. G. Raguraman, Suchetha K. Nalilu and Hari N. Pati, Synthesis and evaluation of a series of 1-substituted tetrazole derivatives as antimicrobial agents, Org. Commun. 3:3 (2010) 45-56.

[15] A.Haleel, D.Mahendiran, V.Veena, N.Sakthivel, A. K. Rahiman, Antioxidant, DNA interaction, VEGFR2 kinase, topoisomerase $\mathrm{I}$ and in vitro cytotoxic activities of heteroleptic copper(II) complexes of tetrazolo[1,5-a]pyrimidines and diimines, Mater. Sci. Eng. C. 68 (2016) 366-382. 
[16]V. A. Ostrovskii, R. E. Trifonov, and E. A. Popova, Medicinal chemistry of tetrazoles, Russian Chem Bulletin, Int Ed. 61 (2012)768-780.

[17]S. Djebbar-Sid, O. Benali-Baitich, and J. P. Deloume, Synthesis, characterization, electrochemical behaviour and catalytic activity of manganese(II) complexes with linear and tripodaltetradentate ligands derived from Schiff bases, Trans. Met. Chem. 23 (1998) 443-447.

[18] S. Belaid, S. Djebbar, O. Benali-Baitich, M. A. Khan, and G. Bouet, Complex formation between manganese (II), cobalt (II), nickel (II), copper (II) and a series of new ligands derived from N, N'-O-phenylenebis (salicylideneimine), C. R. Chim. 10 (2007) 568-572.

[19] S. Djebbar-Sid, O. Benali-Baitich, and J. P. Deloume, Synthesis, characterization and electrochemical behaviour of cobalt(II) and cobalt(III):O2- complexes, respectively, with linear and tripodaltetradentate ligands derived from Schiff bases, J. Mol. Struct. 569 (2001) 121-128.

[20]M. S. Jana, A. K. Pramanik, D. Sarkar, S. Biswas, and T. K. Mondal, Octahedral Mn (II) complex with new NNO donor Schiff base ligand: Synthesis, structure, photoluminescentbehavior and computational studies, Polyhedron. 81 (2014) 66-73.

[21] S. U. Rehman, Z. H. Chohan, F. Naz, C. T. Supuran, In-vitro antibacterial, antifungal and cytotoxic activities of some coumarins and their metal complexes, J. Enz. Inhib. Med. Chem. 20 (2005) 333-340.

[22] S.H. Sumrra, Z. H. Chohan, Synthesis, characterization and biological properties of thienylderivedtriazole Schiff bases and their oxovanadium(IV) complexes, J. Enz. Inhib. Med. Chem. 27 (2012) 187-193.

[23] N.E. Dixon, C. Gazzola, R.L. Blakeley, B. Zerner, Jack bean urease (EC 3.5. 1.5). Metalloenzyme.Simple biological role for nickel, J. Am. Chem. Soc. 97 (1975) 4131-4133.

[24] R.K. Andrews, R.L. Blakeley, B. Zerner, H. Sigel, A. Sigel, Nickel in proteins and enzymes.23 (1988)165-284.

[25] K.C. Skyrianou, E.K. Efthimiadou, V. Psycharis, A. Terzis, D.P. Kessissoglou, G. Psomas, Nickel-quinolonesinteraction. Part 1-Nickel (II) complexeswith the antibacterial drug sparfloxacin: Structureandbiologicalproperties, J. Inorg.Biochem. 103 (2009) 1617-1625.

[26] B. Xu, P. Shi, Q. Guan, X. Shi, G. Zhao, Synthesis, crystal structure, and biological activity of anickel (II) complex constructed by 2-phenyl-4-selenazole carboxylic acid and 1, 10phenanthroline, J. Coord. Chem. 66 (2013) 2605-2614.

[27] R. Kurtaran, L.T. Yildirim, A.D. Azaz, H. Namli, O. Atakol, Synthesis, characterization, crystal structure and biological activity of a novel heterotetranuclear complex: $\left[\mathrm{NiLPb}(\mathrm{SCN})_{2}\right.$ $(\mathrm{DMF})(\mathrm{H} 2 \mathrm{O})] 2$, bis- $\left\{\left[\mu-\mathrm{N}, \mathrm{N}^{\prime}\right.\right.$-bis( salicylidene)-1,3-propanediaminato-aqua

nickel(II)](thiocyanato)( $\mu$-thiocyanato)( $\mu$-N,N'-dimethylformamide)lead(II) $\}$, J. Inorg. Biochem. 99 (2005) 1937-1944. 
[28] H.B. Shawish, W. Wong, Y. Wong, S. Loh, C. Looi, P. Hassandarvish, A. Phan, W. Wong, H. Wang, I.C. Paterson, C. Ea, M. Mustafa, M. Maah, Nickel (II) complex of polyhydroxybenzaldehyde N4-thiosemicarbazone exhibits anti-inflammatory activity by inhibiting

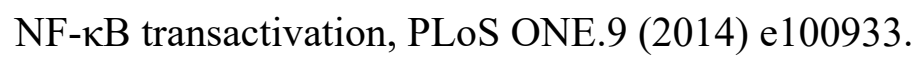

[29]S. Chikhi, S. Djebbar, JF. Soule and H. Doucet, Reactivity of N-protected 5-(2- bromophenyl) tetrazoles in palladium-catalyzed direct arylation of heteroarenes or fluorobenzenes,J. Organ. Chem. 831 (2016) 55-63.

[30]A. Bouchoucha,A. Terbouche,A. Bourouina,S. Djebbar, New complexes of manganese (II), nickel (II) and copper (II) with derived benzoxazole ligands: Synthesis, characterization, DFT, antimicrobial activity, acute and subacute toxicity, J. Inorg. Chim.Acta. 418 (2014) 187-197.

[31] A.D. Becke, Density-functional thermochemistry. III. The role of exact exchange, J. Chem. Phys. 98 (1993) 5648.

[32] C. Lee, W. Yang, R.G. Parr, Development of the Colle-Salvetti correlation-energy formula into a functional of the electron density, Phys. Rev. B. 37 (1998) 785.

[33] M.J. Frisch, G.W. Trucks, H.B. Schlegel, G.E. Scuseria, M.A. Robb, J.R. Cheeseman, J.A. Montgomery, T. Vreven, K.N. Kudin, J.C. Burant, J.M. Millam, S.S. Iyengar, J. Tomasi, V. Barone, B. Mennucci, M. Cossi, G. Scalmani, N. Rega, G.A. Petersson, H. Nakatsuji, M. Hada, M. Ehara, K. Toyota, R. Fukuda, J. Hasegawa, M. Ishida, T. Nakajima, Y. Honda, O. Kitao, H. Nakai, M. Klene, X. Li, J.E. Knox, H.P. Hratchian, J.B. Cross, C. Adamo, J. Jaramillo, R. Gomperts, R.E. Stratmann, O. Yazyev, A.J. Austin, R. Cammi, C. Pomelli, J.W. Ochterski, P.Y. Ayala, K. Morokuma, G.A. Voth, P. Salvador, J.J. Dannenberg, V.G. Zakrzewski, S. Dapprich, A.D. Daniels, M.C. Strain, O. Farkas, D.K. Malick, A.D. Rabuck, K. Raghavachari, J.B. Foresman, J.V. Ortiz, Q. Cui, A.G. Baboul, S. Clifford, J. Cioslowski, B. B. Stefanov, G. Liu, A. Liashenko, P. Piskorz, I. Komaromi, R.L. Martin, D.J. Fox, T. Keith, M.A. Al-Laham, C.Y. Peng, A. Nanayakkara, M. Challacombe, P.M.W. Gill, B. Johnson, W.Chen, M.W. Wong, C. Gonzalez, J.A. Pople, Gaussian 03, Revision A.1, Gaussian Inc, Pittsburgh PA. 2003.

[34] A.E. Reed, L.A. Curtiss, F. Weinhold, Intermolecular interactions from a natural bond orbital, donor-acceptor viewpoint, Chem. Rev. 88 (1988) 899-926.

[35] A.U. Rahman, M.I. Choudhary, W.J. Thomsen, Bioassay Techniques for Drug Development, Harwood Academic Publishers, the Netherlands. 2001.

[36]M. Balouiri, M. Sadiki,S. K. Ibnsouda, Methods for in vitro evaluatingantimicrobialactivity:Areview, J. Pharm. Anal. 6 (2016)71-79.

[37] A. Bouchoucha, A. Terbouche, M. Zaouani, F. Derridj, S. Djebbar, Iron and nickel complexes with heterocyclic ligands: Stability, synthesis, spectral characterization, antimicrobial activity, acute and subacute toxicity, J. Trace. Elem. Med. Biol.27 (2013) 191-202. 
[38] A. Bouchoucha, S. Zaater, S. Bouacida, H. Merazig, S. Djebbar, Synthesis and characterization of new complexes of nickel (II), palladium (II) and platinum(II) with derived sulfonamide ligand: Structure, DFT study, antibacterial and cytotoxicity activities, J. Mol. Struct. 1161 (2018) 345-355. [39]A.G.Ponce,R.Fritz,C.del Valle,S.I.Roura, Antimicrobial activity of essential oils on the native microflora of organic Swiss chard, LWT - Food Science and Technology. 36 (2003) 679-684.

[40] MARSDEN S. BLOIS, Antioxidant Determinations by the Use of a Stable Free Radical, Nature. 181 (1958) 1199-1200.

[41] S. Hussaina , A. Badshaha , B.Lalb , R. A. Hussaina , S. Alia , M. N. Tahirc and A. A. Altaf, New supramolecularferroceneincorporated N,N'-disubstitutedthioureas: synthesis, characterization, DNA binding, and antioxidant studies, J. Coord. Chem. 67:16 (2014) 2148-2159.

[42] F. Kratz, B. Nuber, J. Weib, and B. K. Keppler, Synthesis andCharacterizationof Potential Antitumor and Antiviral Gallium(III) Complexesof $\alpha-(\mathrm{N})$-HeterocyclicThiosemicarbazones, J. Synth. Inorg.Met. Org. Chem. 21 (1991) 1601-1613.

[43] W.J. Geary, The use of conductivity measurements in organic solvents for the characterisation of coordination compounds, Coord. Chem. Rev. 7 (1971) 81-122.

[44] W. J. Geary, The use of conductivity measurements in organic solvents for the characterisation of coordination compounds, Coord. Chem. Rev. 7 (1971) 81-122.

[45] J. Setlik, A. Martvon and J. Lesko, Preparation and spectral properties of tetrazoles, Chemical Papers. 33(4) (1979) 521-527.

[46] P. B. Mohite, R. B. Pandhare, S. G. Khanage and V. H. Bhaskar, Synthesis and in vitro antimicrobial activity of some novel chalcones containing 5-phenyl tetrazole, Pharm. Sci. Acta. 52 (2010) 505-510.

[47] P. B. Mohite, R. B. Pandhare, S. G. Khanage and V. H. Bhzskar, A novel approach for synthesis of substitutesd tetrazoles, J. Nanomater. Bio.Struct. 4 (2009) 803-807.

[48] M. M. Degtyarik, P. N. Gaponik, V. N. Naumenko, A. I. Lesnikovich and M. V. Nikanivich, Infrared spectroscopoic study of copper (II) complexes with N-substitutes tetrazoles, Spectro. Chimica.Acta. 43 (1987) 349-353.

[49] T. Ghosh, B. Mondal, T. Ghosh, M. Sutradhar, G. Mukherjee, Michael G.B. Drew, Synthesis, structure, solution chemistry and the electronic effect of para substituents on the vanadium centerina family of mixed-ligand [VVO(ONO)(ON)] complexes, J. InorganicaChimicaActa. 360 (2007) 1753-1761.

[50] G. Thirunarayanan, M. Gopalakrishnan, G. Vanangamudi, IR and NMR spectral studies of 4bromo-1-naphthyl chalcones-assessment of substituent effects, SpectrochimicaActa Part A. 67 (2007) 1106-1112. 
[51] G. C. Percy and D. A. Thornton, Infrared spectra of N- aryl salicylaldimine complexes substituted in both aryl ring, J. Inorg. Nucl.Chem. 35 (1973) 2319-2327.

[52]S. Belaid, A. Landreau, S. Djebbar, O. B.Battich, M.A. Khan, G. Bouet, Synthesis, characterisation and antifungal activity of a series of Cobalt(II) and Nickel(II) complexes with ligands derived from reduced N, N0-o-Phenylenebis(Salicylideneimine), Transition. Met.Chem. 33 (2008) 511-516.

[53] M. A. Khedr, M. Gaber and H. Abd El-Zaher, Eman, Synthesis, Structural Characterization, and Antimicrobial Activities of $\mathrm{Mn}(\mathrm{II}), \mathrm{Co}(\mathrm{II}), \mathrm{Ni}(\mathrm{II}), \mathrm{Cu}(\mathrm{II})$ and $\mathrm{Zn}(\mathrm{II})$ Complexes of Triazolebased Azodyes, Chin. J. Chem. 29 (2011) 1124-1132.

[54] Z. Travnicek, R. Pastorek, Z. Sindelar, J. Kamenicek and J. Marek, Reactions of bis(isoproplxanthato)nickel(II) with nitrogen or oxygen donor ligands-III. X-ray crystal structure of the complex with pyrazine, Polyhedron. 15 (1996) 2975-2981.

[55] J. R. Weinkauf, S. W. Cooper, A. Schweiger and C.C. Wamser, Substituent and Solvent effects on the Hyperporphyrin Spectra of DiprotonatedTetraphenylporphyrins, J. Phys. Chem. A.107 (2003) 3486-3496.

[56] Hiroshi Fujii, Effects of the Electron-Withdrawing Power of Substituents the Electronic Structure and Reactivity in Oxoiron( IV) on Porphyrin ./r-Cation Radical Complexes, J. Am. Chem. SOC. 115 (1993) 4641-4648.

[57]S. Djebbar-Sid,O. Benali-Baitich,M. A. Khan and G. Bouet, Synthesis, Characterisation and Electrochemical Behaviour of some Nickel (II) Complexes with Linear and TripodalTetradentate Ligands Derived From Schiff Bases, Synth. React. Inorg. Met-Org. Chem. 27 (1997) 1219-1233.

[58]Z. H. Chohan, C. T. Supuran and A. Scozzafava, metalloantibiotics: Synthesis and Antibacterial Activity of Cobalt (II), Copper (II), Nickel (II) and Zinc (II) complexes, J. Enzym. Inhib . Med. Chem. 19 (2004) 79-84.

[59] S. Belaid, A. Landreau, S. Djebbar, O. B. Baitich, M. A. Khan and G. Bouet, S. Belaid, A. Landreau, S. Djebbar, O. B. Baitich, M. A. Khan and G. Bouet, Synthesis, characterisation and antifungal activity of a series of Cobalt (II) and Nickel(II) complexes with ligands derived from reduced N, N'-o-Phenylenebis(Salicylideneimine), Transit. Met. Chem. 33 (2008) 511-516.

[60] A. Terbouche, S. Djebbar, O. B. Baitich, F. Balegroune, K. Taibi, M. Allain and M. Sallé, Characterization and Complexing Capacity of Humic Acid Extracted from Yakouren Soil with Heavy Metals by Conductimetry and Quenching of Fluorescence. Inorg.Met. Org. Chem. 39 (2009) 925-932.

[61] A. I. Lesnikovich, O. A. Ivashkevich, S. V. Levchik, A. I. Balabanovich, P. N. Gaponik and A. A. Kulak, Thermal decomposition on aminotetrazoles, Thermochim. Acta. 388 (2002) 233-251. 
[62] A. I. Lesnikovich, S. V. Levchik, A. I. Balabanovich, O. A. Ivashkevich and P. N. Gaponik, The thermal decomposition of tetrazoles, Thermochim. Acta. 200 (1992) 427-441.

[63] M. Turkyilmaz, A. Onder and Y. Brana, Synthesis, spectroscopic, and thermal properties of some azomethine complexes of $\mathrm{Cu}$ (II), Ni (II) and Pt (II), J. Therm. Anal. Calorim. 109 (2012) 991-998.

[64] H. B. Schegel, Optimization of Equilibrium Geometries and Transition Structures, J. Comput. Chem. 3 (1982) 214-218.

[65] N.T. Abdel Ghani and A. M. Mansour, Novel Pd (II) complexes of N,N-donor benzimidazole ligand : Synthesis, spectral, electrochemical, DFT studies and evaluation of biological activity, J.Inorg. Chem. Acta. 373 (2011) 249-258.

[66]S. Sadaoui-Kacel, S. Zaater, N. Bensouilah and S. Djebbar, Novel repaglinide complexes with manganese (II), iron (III), copper (II) and zinc (II): Spectroscopic, DFT characterization and electrochemical behaviour, J. Struct. Chem. 57 (2016) 1519-153.

[67]Shi-Liang Chen, Zheng Liu, Jie Liu, Guo-Cheng Han, Yan-Hong Li, Synthesis, characterization, crystal structure and theoretical approach of $\mathrm{Cu}(\mathrm{II})$ complex with 4-\{(Z)- [(2 hydroxybenzoyl) hydrazono] methyl \}benzoic acid, J. Mol. Struct. 1014 (2012) 110-118.

[68] N. Tidjani-Rahmouni, N. E. H. Bensiradj, S. Djebbar, and O. Benali-Baitich, Synthesis, characterization, electrochemical studies and DFT calculations of amino acids ternary complexes of copper (II) with isonitrosoacetophenone. Biological activities,J. Mol. Struct. 1075 (2014) 254-263.

[69] A. M. Mansour, Coordination behavior of sulfamethazine drug towards $\mathrm{Ru}(\mathrm{III})$ and $\mathrm{Pt}(\mathrm{II})$ ions: Synthesis, spectral, DFT, magnetic, electrochemical and biological activity studies, Inorg. Chim .Acta. 394 (2013) 436-445.

[70] C. T. Zeyrek, H. Unver, Ö. T. Arpacı, K. Polat, N. O. İskeleli and M. Yildiz, Experimental and theoretical characterization of the 2-(4-bromobenzyl)-5-ethylsulphonyl-1,3-benzoxazole, J. Mol. Struct. 1081 (2015) 22-37.

[71] A. Ghosh, A. Sarkar, P. Mitra, A. Banerji, J. Banerjee, S. Mandal and M. Das, Crystal structure and DFT calculations of 3,4-seco-lup-20(29)-en-3-oic acid isolated from Wrightiatinctoria: Stacking of supramolecular dimers in the crystal lattice, J.Mol. Struct. 980 (2010) 7-12.

[72] C. Femoni, S. Muzzioli, A. Palazzi, S. Stagni, S. Zacchini, F. Monti, G. Accorsi, M. Bolognesi, N. Armaroli, M. Massi, G. Valenti and M. Marcaccio, New tetrazole-based Cu(I) homo- and heteroleptic complexes with various $\mathrm{P}^{\wedge} \mathrm{P}$ ligands: synthesis, characterization, redox and photophysical properties, Dalton Trans. 42 (2013) 997-1010.

[73] P. Bera, P. Brandão, G. Mondal, A. Santra, A. Jana, R.B. Mokhamatam, S.K. Manna, T.K. Mandal, P. Bera, An unusual iminoacylation of 2-amino pyridyl thiazole: Synthesis, X-ray 
crystallography and DFT study of copper(II) amidine complexes and their cytotoxicity, DNA binding and cleavage study, Polyhedron. 159 (2019) 436-445.

[74]E. Belhadj, A. El-Ghayoury, T. Cauchy, M. Allain, M. Mazari and M. Sallé, TetrathiafulvaleneBased Phenanthroline Ligands: Synthesis, Crystal Structures, and Electronic Properties, Eur. J. Inorg. Chem. (2014) 3912-3919.

[75] L. Boudiba, L. Kaboub, A. Gouasmia, J. M. Fabre, New Semiconducting Benzo-TTF Salts: Synthesis and Physical Properties, Synthesis. 8 (2005) 1291-1296.

[76] A. Urooj, A. Lashin, R. Abbasi, U.A. Rana, N. Al-Arifi, G. S. Khan, S. Ali, Heinz-Bernhard Kraatz and A. Shah, pH and Temperature Responsive Electrooxidation of Thiazole Derivatives and Preliminary Screening of Their Antioxidant Activity, J. Electrochem. Soc. 163 (2016) H350-H358.

[77] F. Pointillart, T. Cauchy, Y. L. Gal, S. Golhen, O. Cador and L.Ouahab, Experimental and Theoretical Studies on Photophysical Properties: Tuning Redox-Active Amido-Tetrathiafulvalene Derivatives in Paramagnetic Coordination Complexes, J. Inorg. Chem. 49 (2010) 1947-1960.

[78] S. Stagni, E. Orselli, A. Palazzi, L. De Cola, S. Zacchini, C. Femoni, M. Marcaccio, F. Paolucci and S. Zanarini, Polypyridyl Ruthenium(II) Complexes with Tetrazolate-Based Chelating Ligands. Synthesis, Reactivity, and Electrochemical and Photophysical Properties, J. Inorg. Chem.46 (2007) 9126-9138.

[79] R. Prabhakaran, R. Sivasamy, J. Angayarkanni, R. Huang, P. Kalaivani, R. Karvembu, F. Dallemer and K. Natarajan, Topoisomerase II inhibition activity of new square planar Ni(II) complexes containing N-substituted thiosemicarbazones: Synthesis, spectroscopy, X-ray crystallography and electrochemical characterization,Inorg. Chim.Acta. 374 (2011) 647-653.

[80] J. Costamagna, J. Vargas, R. Latorre, A. Alvarado and G. Mena, Coordination compounds of copper, nickel and iron with Schiff bases derived from hydroxynaphthaldehydes and salicylaldehydes,Coord. Chem. Rev. 119 (1 992) 67-88.

[81] A. E. Tai, E. J. Lien, M. Mc Lai and T. A. Khwaja, Novel N-hydroxyguanidine derivatives as anticancer and antiviral agents, J. Med. Chem. 27 (1984) 236-238.

[82] S. Akcha, L. Hammal, S. Triki, L. Lezama, B. Nedjar-Kolli and O. B. Baitich, Copper(II) and nickel(II) complexes derived from a carbothioamide-5-pyrazolone ligand: synthesis, characterization, crystal structures, electrochemical, potentiometric and DNA-binding studies, Coord. Chem. Rev.68 (2015)4373-4394. 
[83] E Pereira, L Gomes, B de Castro, Synthesis, spectroscopic and electrochemical study of nickel (II) complexes with tetradentate asymmetric Schiff bases derived from salicylaldehyde and methyl2-amino-1-cyclopentenedithiocarboxylate, J. Inorg. Chim.Acta. 271 (1998) 83-92.

[84] A.M. Vijesh, A. M. Isloor, S. Telkar, S.K. Peethambar, S. Rai, N. Isloor, synthesis, charachterization and antimicrobial studies of some new pyrazole incorporated imidazole derivatives, Eur. J. Med. Chem. 46 (2011) 3531-3536.

[85] A. A. El-Sherif, Synthesis, spectroscopic characterization and biological activity on newly synthesized copper (II) and nickel (II) complexes incorporating bidentate oxygen-nitrogen hydrazone ligands, J. Inorg. Chimi.Acta. 362 (2009) 4991-5000.

[86] R. Kenchappa, Y. D. Bodke, B. Asha, S. Telkar and M. A. Sindhe, Synthesis, antimicrobial, and antioxidant activity of benzofuranbarbitone and benzofuranthiobarbitone derivatives, J. Med. Chem. Res. 23 (2014) 3065-3081.

[87] K. Dileep, S. Polepalli, N. Jain, S. K. Buddana, R. S. Prakasham, M. S. R. Murty, Synthesis of novel tetrazole containing hybrid ciprofloxacin and pipemidic acid analogues and preliminary biological evaluation of their antibacterial and antiproliferative activity, J. Mol. Divers. 22 (2018) 83-93.

[88] M. Mondelli, V. Brune', G. Borthagaray, J. Ellena, O. R. Nascimento, C. Q. Leite, A. A. Batista, M. H. Torre, New Ni(II)-sulfonamide complexes: Synthesis, structural characterization and antibacterial properties. X-ray diffraction of $\left[\mathrm{Ni}(\text { sulfisoxazole })_{2}\left(\mathrm{H}_{2} \mathrm{O}\right)_{4}\right] \quad \nexists \quad 2 \mathrm{H} 2 \mathrm{O}$ and [Ni(sulfapyridine)2], J. Inorg. Biochem. 102 (2008) 285-292.

[89] A. Chaudhary and R. V. Singh, Synthetic, Structural and Biological Studies on Divalent Tin Complexes of Sixteen to Twenty-Four Membered Tetraaza Macrocycles, Phosphorus Sulfur Silicon Relat.Elem.178 (2003) 603-613.

[90] R. S. Upadhayaya, S. Jain, N. Sinha, N. Kishore, R. Chandra and S. K. Arora, Synthesis of novel substituted tetrazoles having antifungal activity, Eur. J. Med. Chem. 39 (2004) 579-592.

[91] S. Bondok, W. Fadaly, M. A. Metwally, Synthesis and antimicrobial activity of some new thiazole, thiophene and pyrazole derivatives containing benzothiazole moiety, Eur. J. Med. Chem. 45 (2010) 3692-3701.

[92] S. Akcha, S. Gómez-Ruiz,S. Kellou-Tairi, L. Lezama,F. B. Pérez and O. Benali-Baitich, Synthesis, characterization, solution equilibria, DFT study, DNA binding affinity and cytotoxic properties of a cobalt(II) complex with a 5-pyrazolone ligand, J. Inorg. Chim.Acta. 482 (2018) 738748.

[93] A. Terbouche, C. Ait-Ramdane-Terbouche, S. Djebbar, D. Gerniche, R. Bagtache, N. E. H. Bensiradj, A. Saal, and D. Hauchard, A new ternary ruthenium(III) complex with 1,3 bis(salicylideneamino) propan-2-ol and 3-picolylamine: Synthesis, characterization, density 
functional theory and preparation of electrochemical sensor for nitrite analysis, J. Mol. Struct.1076 (2014) 501-511.

[94] K. Pegklidou, C. Koukoulitsa, I. Nicolaou and V. J. Demopoulos, Design and synthesis of novel series of pyrrole based chemotypes and their evaluation as selective aldose reductasinhibitiors. A case of bioisosterism between a carboxylic acid moiety and that of a tetrazole, J. Bioorg. Med. Chem. 18 (2010) 2107-2114.

[95] Mei-Hsiu Shih and Fang-Ying Ke, Synthesis and evaluated of antioxidant activity of sydnonyl substituted thiazolidinone and thiazoline derivatives, J. Bioorg. Med. Chem. 12 (2004) 4633-4643. [96] S. Zouari, M. Ketata, N. Boudhrioua and E. Ammar, Allium roseum L. volatile compounds profile and antioxidant activity for chemotype discrimination-Case study of the wild plant of Sfax (Tunisia), Ind. Crop. Prod. 41 (2013) 172-178.

[97] D. S. Raja, N. S. P. Bhuvanesh and K. Natarajan, Effect f N(4)-Phenyl Substitution in 2-Oxo1,2-dihydroquinoline-3-carbaldehyde Semicarbazone on the structure, DNA/Protein Interaction, and Antioxidative and Cytotoxic Activity of Cu (II), J. Inorg. Chem. 50 (2011) 12852-12866.

[98] G.W. Gokel, Indole, the aromatic element of tryptophan, as a pi-donor and amphiphilicheadgroup, International Congress Series. 1304 (2007)1-14.

[99] D.F.V. Lewis, C. Loannides, D.V. Parke, Interaction of a series of nitriles with the alcoholinducible isoform of P450: computer analysis of structure-activity relationships, Xenobiotica. 24 (1994) 401-408.

[100] S.Belaid, Complexes de manganèse (II), cobalt (II), nikel (II) et cuivre (II) avec des basses de schiff réduites. Stabilité en solution, synthèse, caractérisation et activité biologique, Doctoral thesis : Chemistry, Alger : Université des sciences et de la technologie Houari-Boumédiène. 2008, $123 p$.

\section{Declaration of interests}

The authors declare that they have no known competing financial interests or personal relationships that could have appeared to influence the work reported in this paper.

$\square$ The authors declare the following financial interests/personal relationships which may be considered as potential competing interests: 
Scheme 1.Structure of the different ligands.

Fig.1. Experimental Infrared vibrational spectra of $\mathrm{L}^{4}$ ligand (red line) and $\mathrm{Ni}-\mathrm{L}^{4}$ complex (blue line) and Simulated IR spectrum of $\mathrm{Ni}-\mathrm{L}^{4}$ complex (black line).

Fig. 2. Electronic spectra of (a) $\mathrm{L}^{5}$ and $(b+c) \mathrm{Ni}-\mathrm{L}^{5}$.

Fig. 3. Thermal decomposition of Ni-L $\mathrm{L}^{1}$.

Fig. 4. Mechanism of the thermal decomposition of Ni-L $\mathrm{L}^{1}$.

Fig. 5. Optimized structures of $\mathrm{L}^{1}$ ligand (a) and Ni- $\mathrm{L}^{1}$ complex(b).

Fig. 6. Energy levels of the HOMO, LUMO and energy gap for the free ligands.

Fig. 7. Energy levels of the HOMO, LUMO and energy gap for the synthesized complexes

Fig. 8. Cyclic voltammogram of $\mathrm{L}^{5}$ ligand at $10^{-3} \mathrm{M}$ in DMSO $\left(100 \mathrm{mV} \cdot \mathrm{S}^{-1}\right)$.

Fig.9. Values of inhibition zone diameter ( $\mathrm{nm}$ ) obtained by tetrazole derivatives and their nickel (II) complexes against bacterial strains

Fig.10. Values of inhibition zone diameter $(\mathrm{nm})$ obtained by tetrazole derivatives and their nickel (II) complexes against fungal strains 


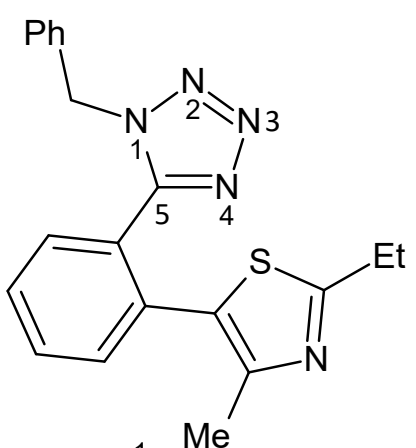

$\mathrm{L}^{1}$

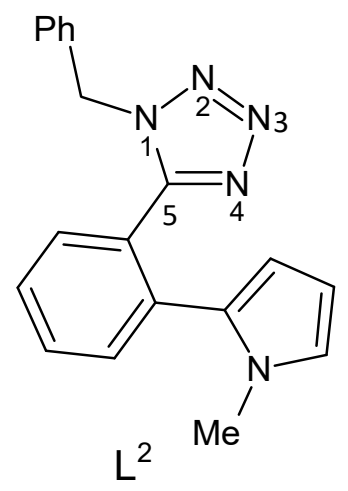

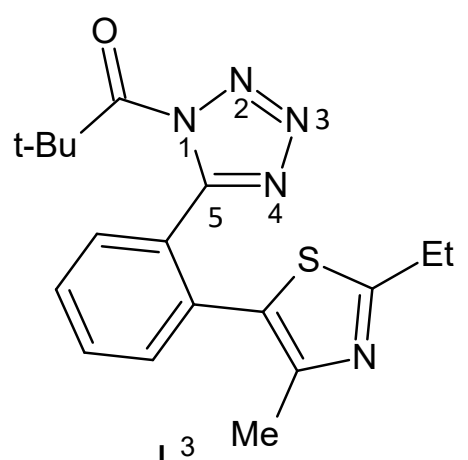

$\mathrm{L}^{3}$

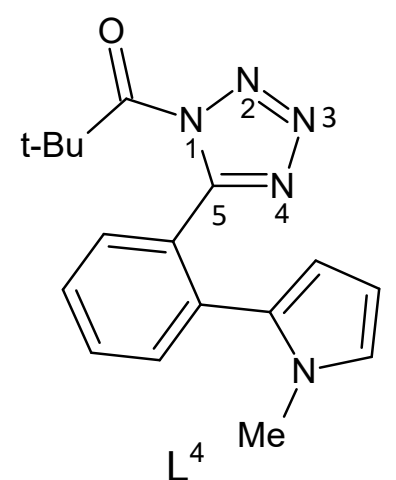

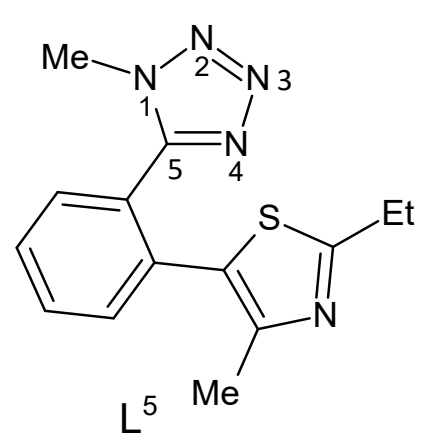

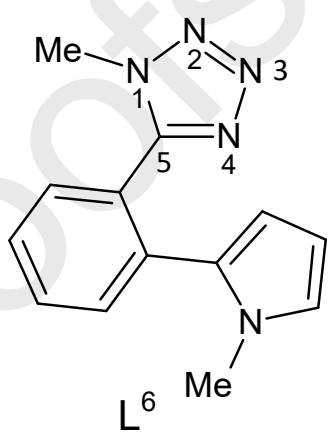

Scheme 1.Structure of the different ligands

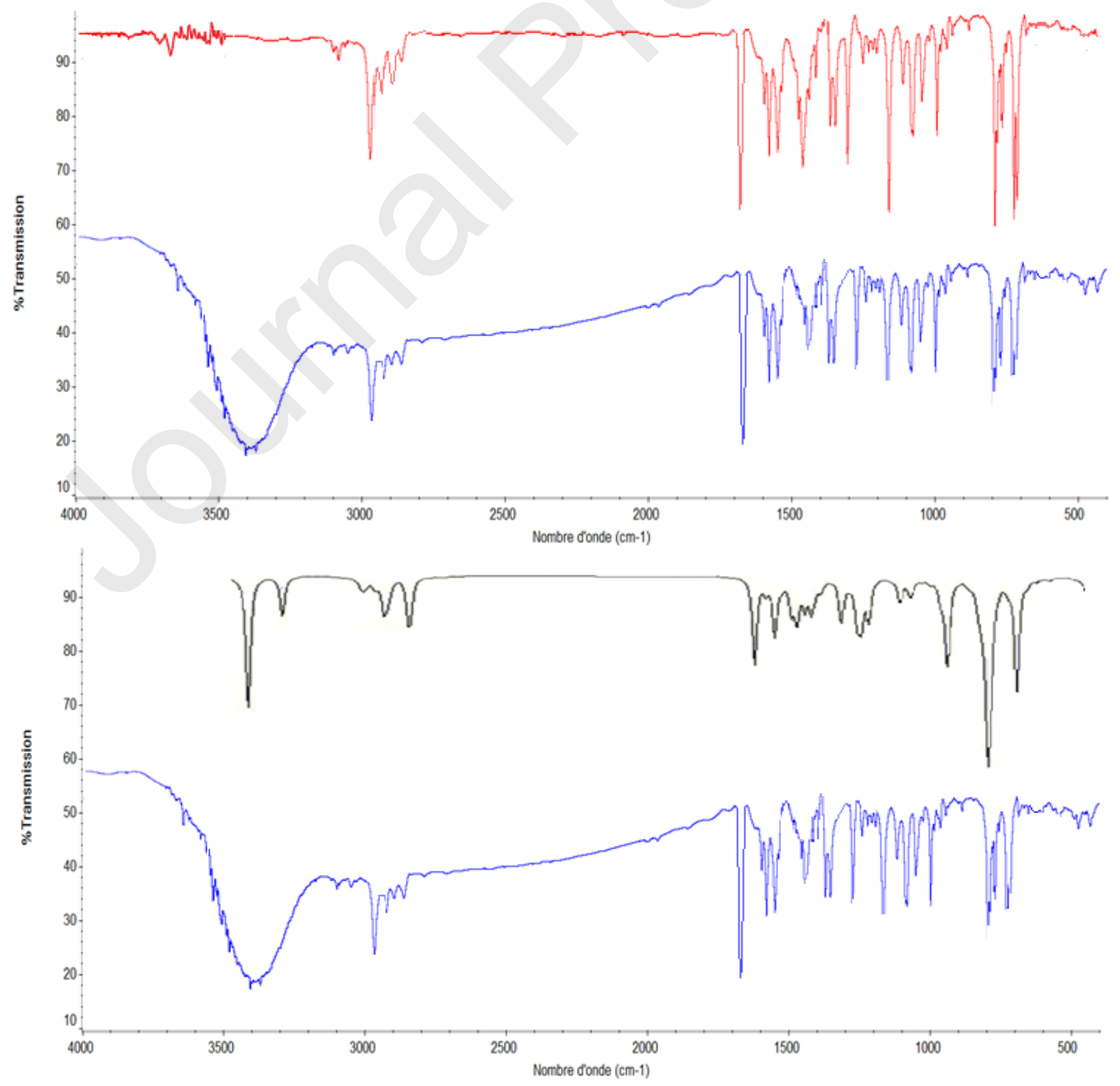


Fig.1.Experimental Infrared vibrational spectra of $\mathrm{L}^{4}$ ligand (red line) and $\mathrm{Ni}-\mathrm{L}^{4}$ complex (blue line) and Simulated IR spectrum of $\mathrm{Ni}-\mathrm{L}^{4}$ complex (black line).
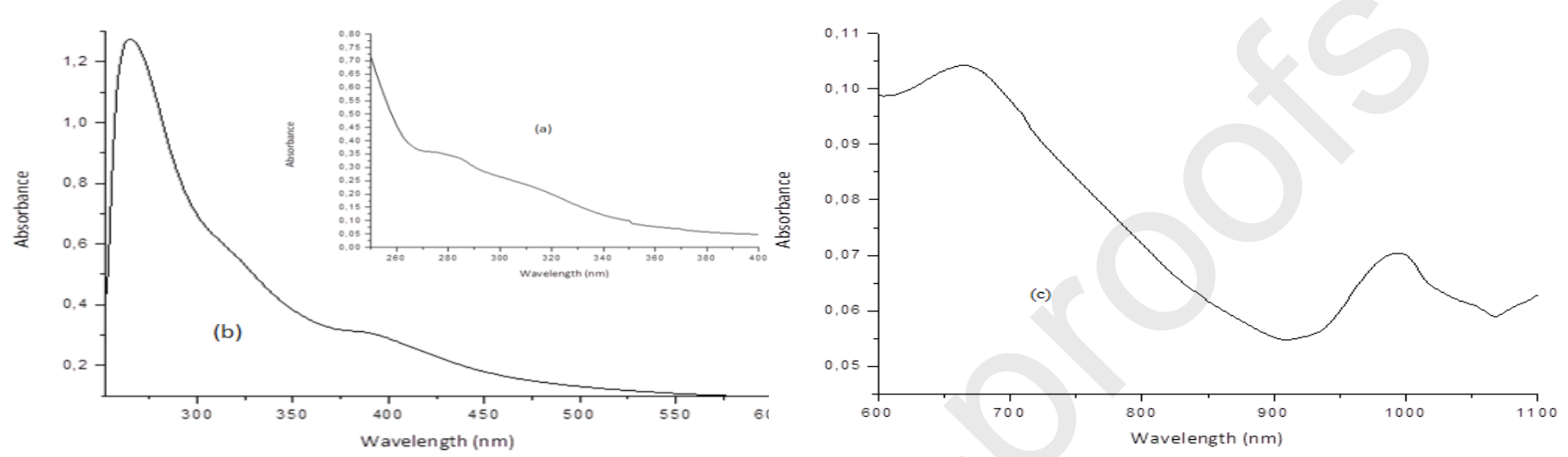

Fig. 2. Electronic spectra of (a) $\mathrm{L}^{5}$ and $(b+c) N i-L^{5}$

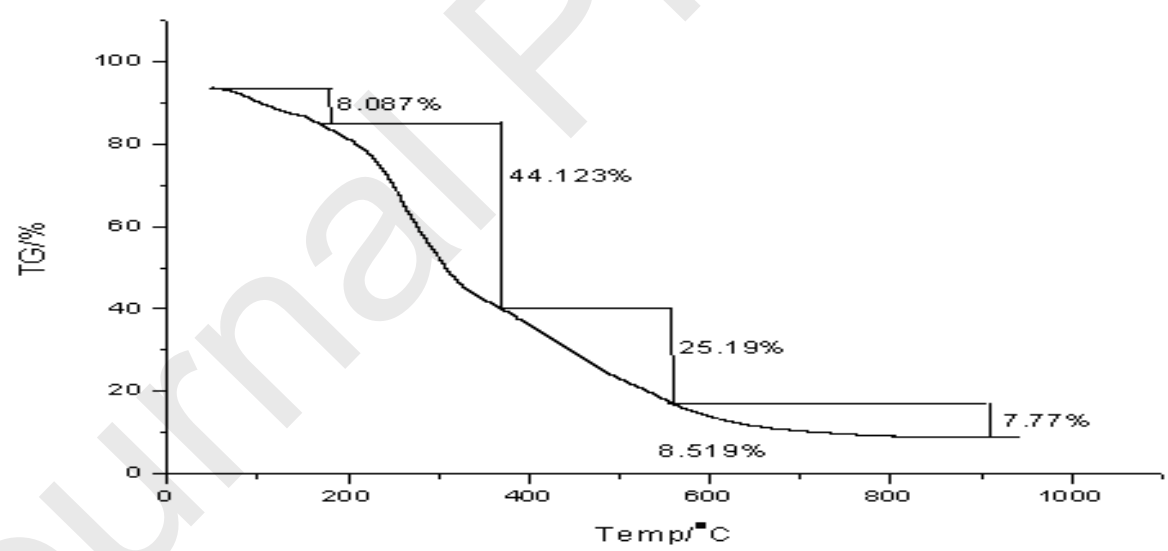

Fig. 3.Thermal decomposition of Ni-L ${ }^{1}$. 


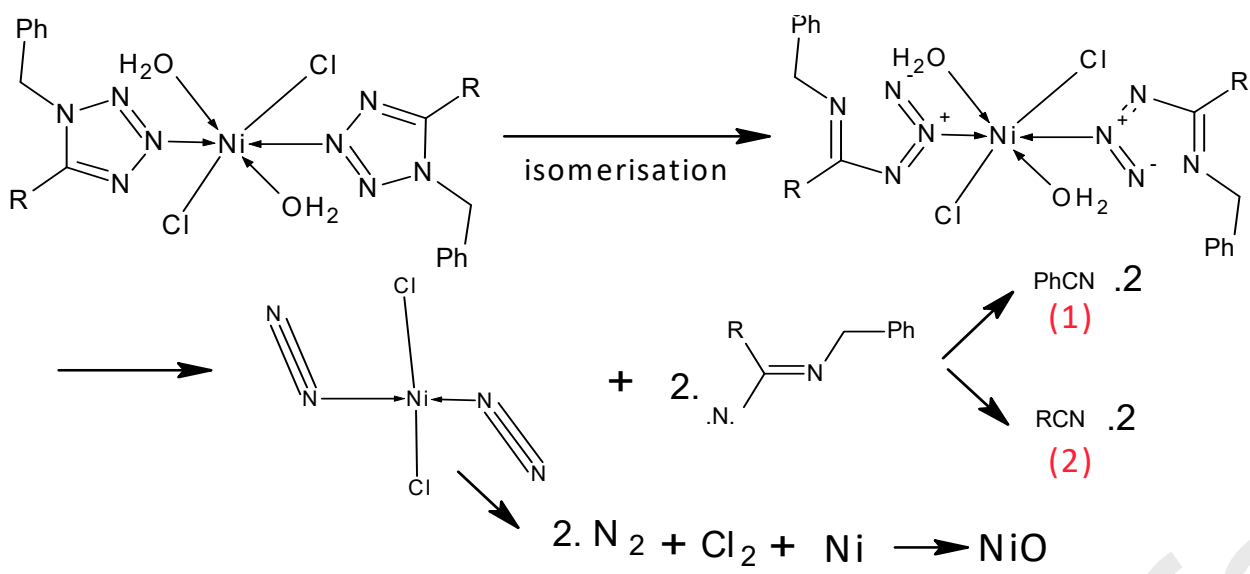

(3)

Fig. 4. Mechanism of the thermal decomposition of $\mathrm{Ni}-\mathrm{L}^{1}$.

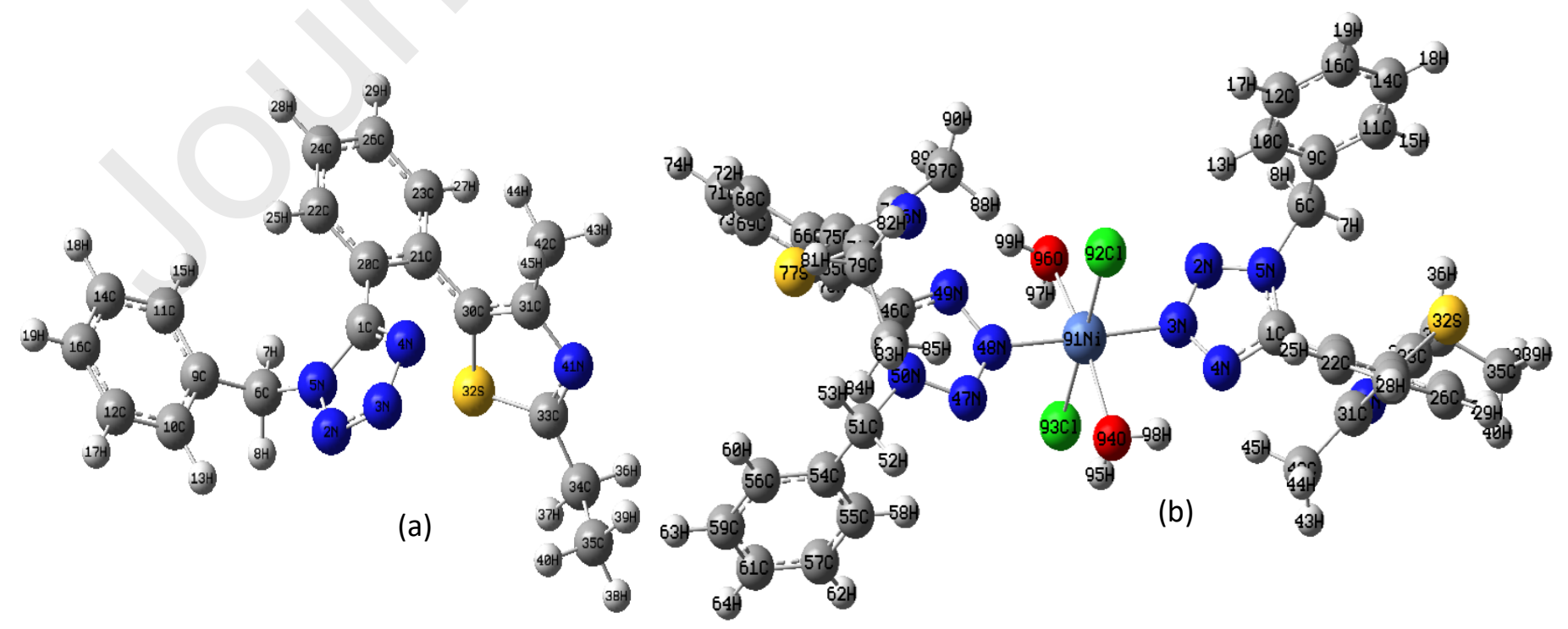


Fig. 5. Optimized structures of $\mathrm{L}^{1}$ ligand(a) and $\mathrm{Ni}-\mathrm{L}^{1}$ complex(b)..
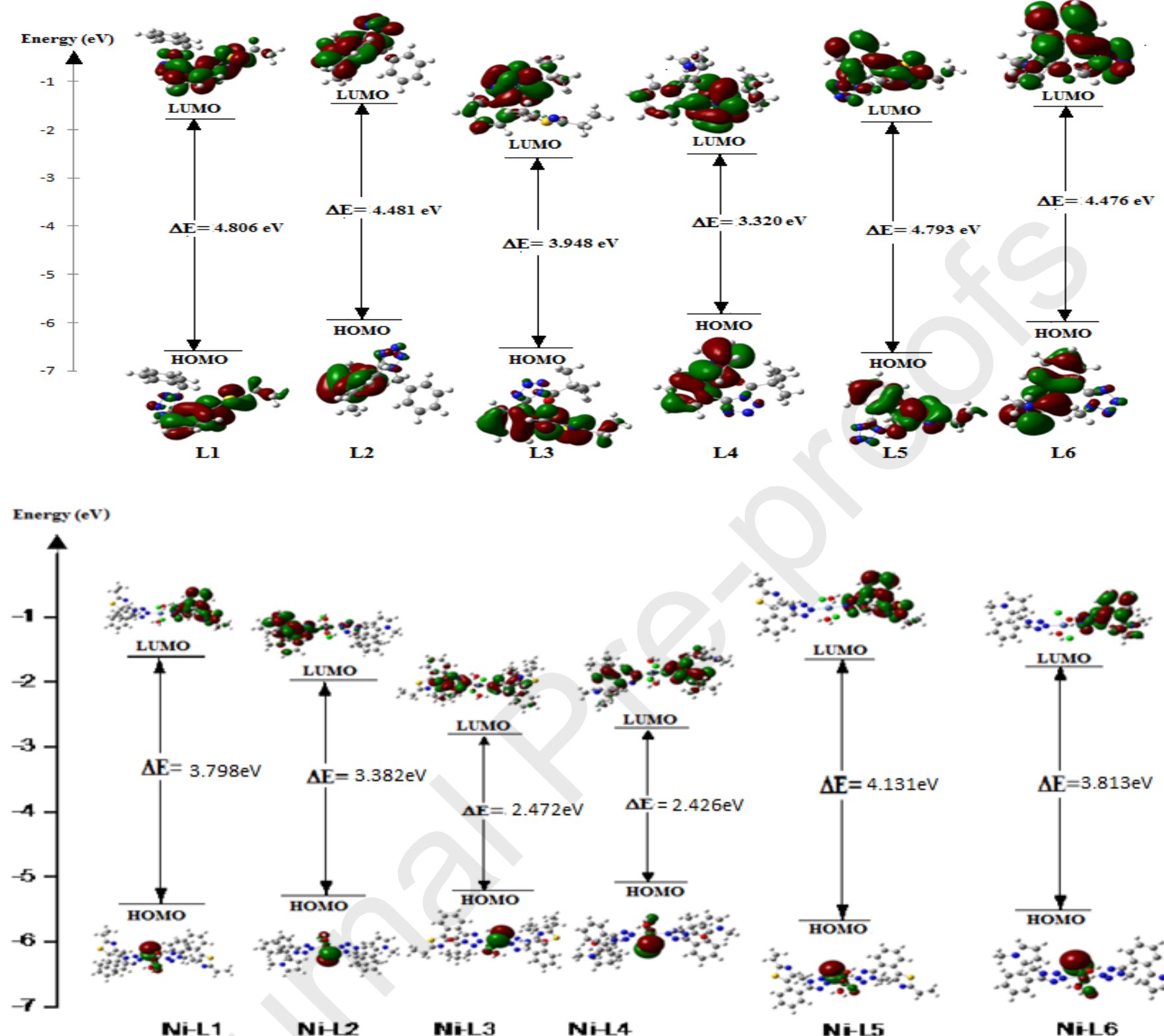

Fig. 6. Energy levels of the HOMO, LUMO and energy gap for the free ligands.

Fig. 7. Energy levels of the HOMO, LUMO and energy gap for the synthesized complexes

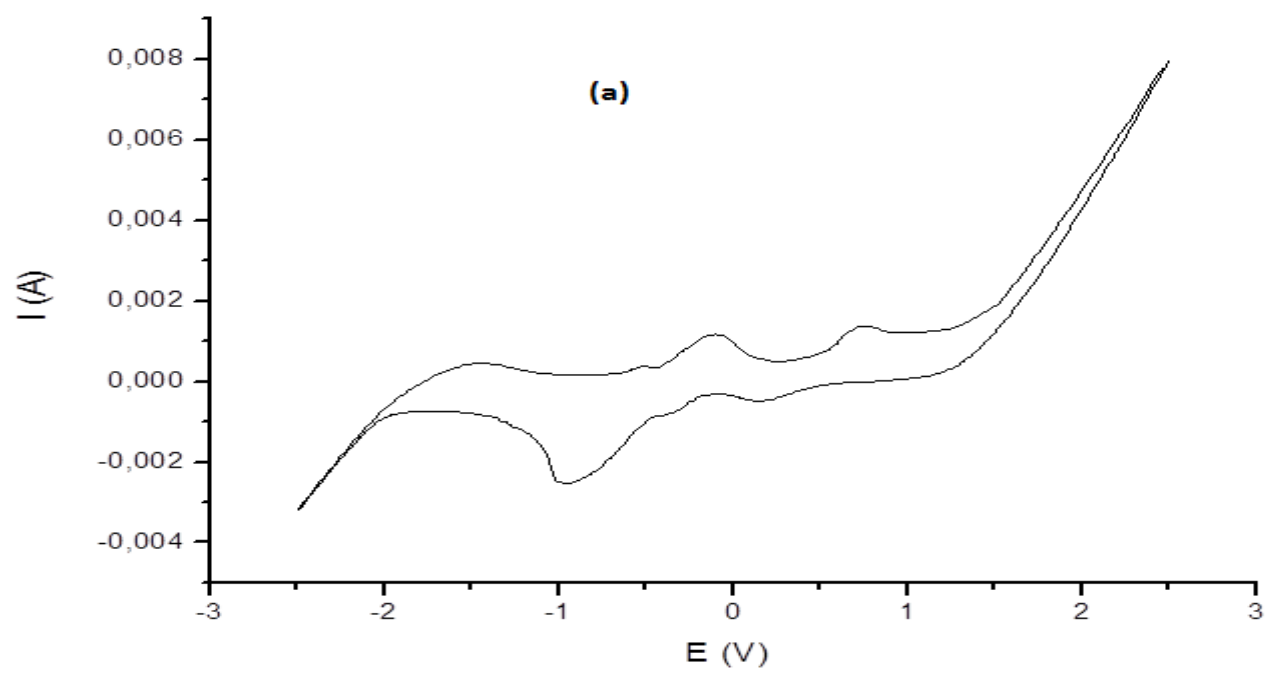


Fig. 8. Cyclic voltammogram of $\mathrm{L}^{5}$ ligand at $10^{3} \mathrm{M}$ in DMSO $\left(100 \mathrm{mV} \cdot \mathrm{S}^{-1}\right)$.

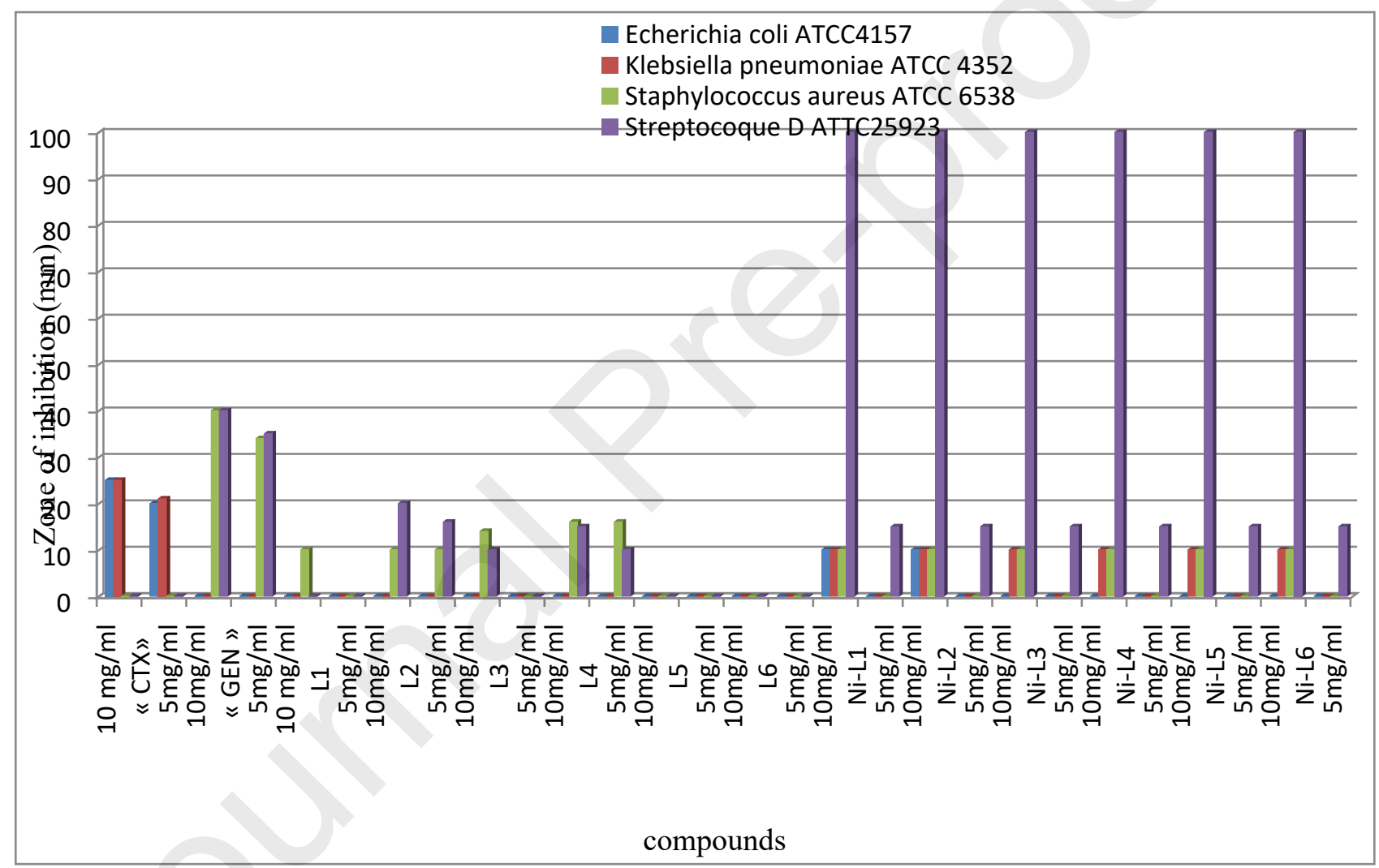

Fig.9. Values of inhibition zone diameter (nm) obtained by tetrazole derivatives and their nickel (II) complexes against bacterial strains 


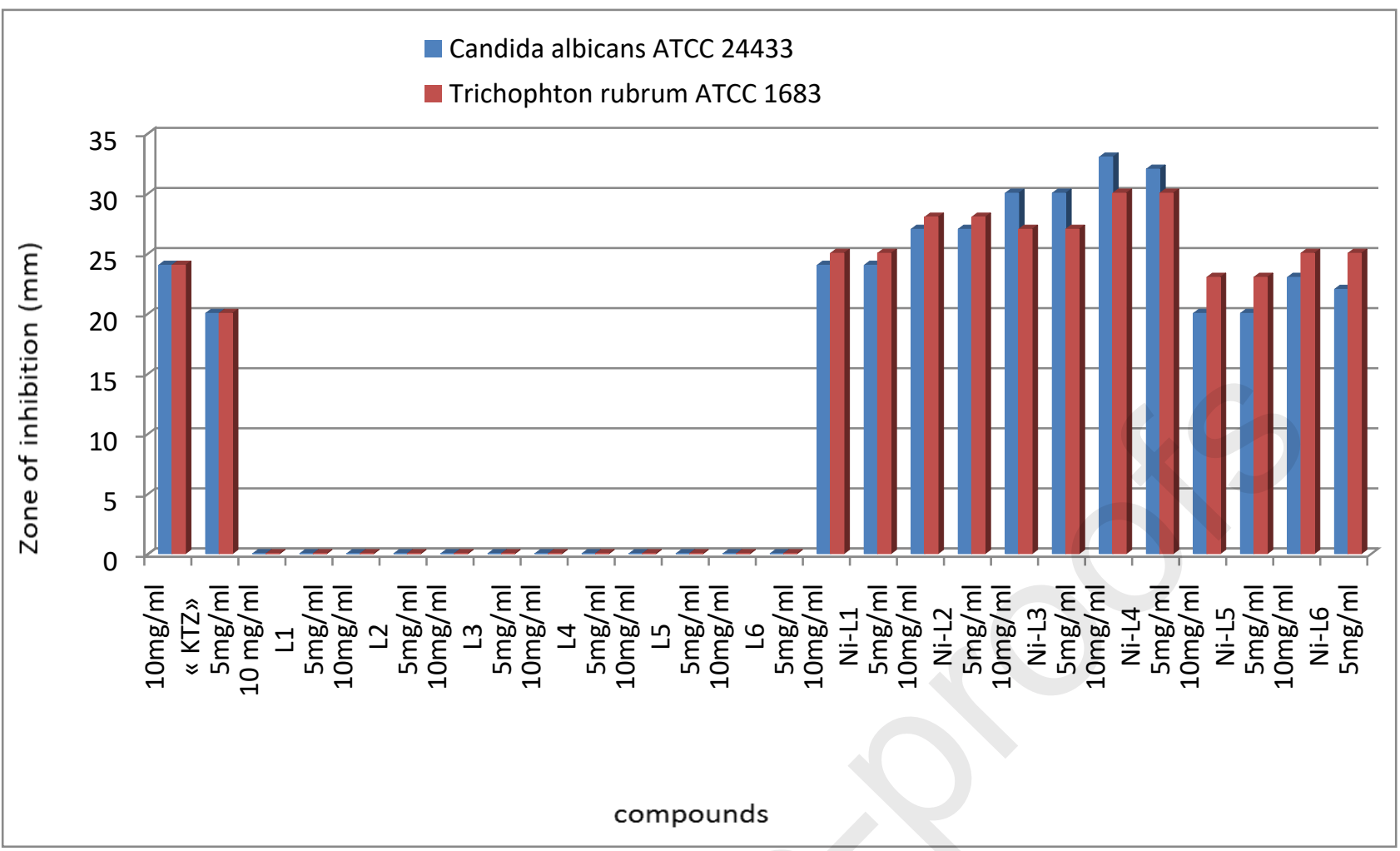

Fig.10. Values of inhibition zone diameter $(\mathrm{nm})$ obtained by tetrazole derivatives and their nickel (II) complexes against fungal strains

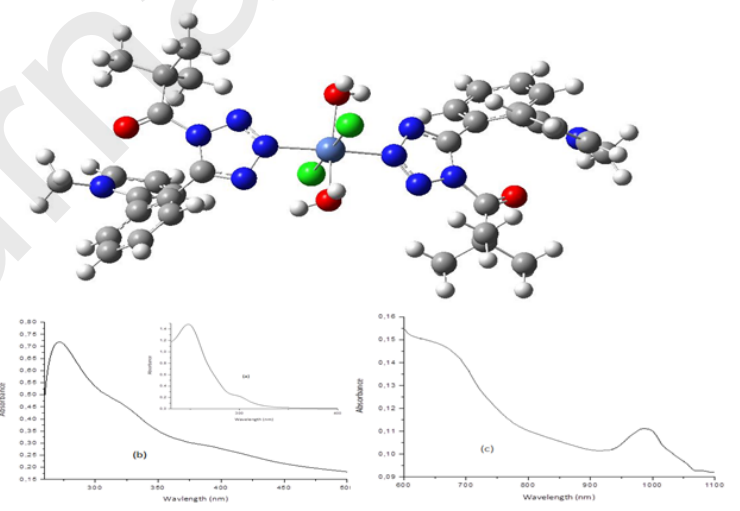

\section{Highlights}


- Novel Ni (II) complexes with a series of tetrazole derivatives have been characterized.

- Thermogravimetric analysis of the complexes has been performed.

- Octahedral structures for the Ni (II) complexes have been proposed and confirmed by DFT calculations.

- The electrochemical behavior was determined by cyclic voltammetry.

- The complexes showed good antimicrobial activities.

- The antioxidant activity of these complexes has been evaluated.

- The effect of the functionalized tetrazole ring on the electrochemical behavior and biological activities has been carefully studied.

Table 1. Physical properties of the metal complexes.

Table 2.The main absorbance bands $\left(\mathrm{cm}^{-1}\right)$ in FT-IR spectra and their assignments for the ligands and their complexes.

Table 3.The main absorbance bands (cm-1) of the ligands in UV-visible and their assignments.

Table4 The main absorbance bands (cm-1) of $\mathrm{Ni}$ (II) complexes in UV-visible and their assignments.

Table 5.Thermogravimetric results of the complexes.

Table 6.Calculated structural parameters and NBO charge of the ligands and their complexes.

Table 7.Energy properties of the ligands and their complexes.

Table8.Binding energies of the complexes obtained at DFT level.

Table 9.Redox potentials of the ligands.

Table 10.Redox potentials of the nickel complexes.

Table 11.Antioxidant activity of the ligands and their complexes. 
Table 1. Physical properties of the metal complexes.

\begin{tabular}{|c|c|c|c|c|}
\hline Complexes & Melting point ${ }^{\circ} \mathrm{C}$ & Yield \% & $\begin{array}{l}\text { Conductance } \\
\Omega^{-1} \mathrm{~cm}^{2} \mathrm{~mol}^{-1}\end{array}$ & $\begin{array}{c}\mu_{\mathrm{eff}} \\
\text { (B.M) }\end{array}$ \\
\hline$\left[\mathrm{Ni} \mathrm{L}_{2}{ }_{2} \mathrm{Cl}_{2}\left(\mathrm{H}_{2} \mathrm{O}\right)_{2}\right] .2 \mathrm{H}_{2} \mathrm{O}$ & $>300$ & 55 & 18 & 3.01 \\
\hline$\left[\mathrm{Ni} \mathrm{L}_{2}{ }_{2} \mathrm{Cl}_{2}\left(\mathrm{H}_{2} \mathrm{O}\right)_{2}\right] .2 \mathrm{H}_{2} \mathrm{O}$ & $>300$ & 51 & 26 & 3.14 \\
\hline$\left[\mathrm{Ni} \mathrm{L}_{2}^{3} \mathrm{Cl}_{2}\left(\mathrm{H}_{2} \mathrm{O}\right)_{2}\right] .2 \mathrm{H}_{2} \mathrm{O}$ & $>300$ & 39 & 37 & 3.30 \\
\hline$\left[\mathrm{Ni} \mathrm{L}_{2}{ }_{2} \mathrm{Cl}_{2}\left(\mathrm{H}_{2} \mathrm{O}\right)_{2}\right] .2 \mathrm{H}_{2} \mathrm{O}$ & $>300$ & 46 & 41 & 3.41 \\
\hline$\left[\mathrm{Ni} \mathrm{L}_{2}^{5} \mathrm{Cl}_{2}\left(\mathrm{H}_{2} \mathrm{O}\right)_{2}\right] .2 \mathrm{H}_{2} \mathrm{O}$ & $>300$ & 54 & 33 & 2.77 \\
\hline$\left[\mathrm{Ni} \mathrm{L}_{2}{ }_{2} \mathrm{Cl}_{2}\left(\mathrm{H}_{2} \mathrm{O}\right)_{2}\right] .2 \mathrm{H}_{2} \mathrm{O}$ & $>300$ & 56 & 13 & 2.82 \\
\hline
\end{tabular}


Table 2. The main absorbance bands $\left(\mathrm{cm}^{-1}\right)$ in FT-IR spectra and their assignments for the ligands and their complexes.

\begin{tabular}{|c|c|c|c|c|c|c|c|}
\hline Compound & $v(\mathrm{C}=\mathrm{N})_{\text {tetrazole }}$ & $v(\mathrm{~N}=\mathrm{N})$ & $v(\mathrm{~N}-\mathrm{N}=\mathrm{N})$ & $v(\mathrm{OH})_{\mathrm{H} 2 \mathrm{OCoord}}$ & $v(\mathrm{C}=\mathrm{O})$ & $v(\mathrm{M}-\mathrm{O})$ & $v(\mathrm{M}-\mathrm{N})$ \\
\hline \multirow[t]{2}{*}{$\mathrm{L}^{1}$} & 1510 & 1457 & 1329 & - & - & - & - \\
\hline & (1518) & (1459) & (1326) & & & & \\
\hline \multirow[t]{2}{*}{$\mathrm{L}^{2}$} & 1514 & 1461 & 1316 & - & - & - & - \\
\hline & (1497) & (1452) & (1311) & & & & \\
\hline \multirow[t]{2}{*}{$\mathrm{L}^{3}$} & 1489 & 1452 & 1326 & - & 1687 & - & - \\
\hline & (1481) & (1457) & (1330) & & (1691) & & \\
\hline \multirow[t]{2}{*}{$\mathrm{L}^{4}$} & 1494 & 1456 & 1309 & - & 1683 & - & - \\
\hline & (1491) & (1465) & (1311) & & (1681) & & \\
\hline \multirow[t]{2}{*}{$\mathrm{L}^{5}$} & 1483 & 1447 & 1319 & - & - & - & - \\
\hline & (1476) & (1466) & (1318) & & & & \\
\hline \multirow[t]{2}{*}{ L6 } & 1488 & 1452 & 1284 & - & - & - & - \\
\hline & (1482) & (1458) & (1278) & & & & \\
\hline \multirow[t]{2}{*}{$\mathrm{Ni}-\mathrm{L}^{1}$} & 1500 & 1431 & 1254 & 3479 & - & 467 & 525 \\
\hline & (1492) & (1418) & (1252) & $(3526)$ & & (424) & (521) \\
\hline \multirow[t]{2}{*}{$\mathrm{Ni}-\mathrm{L}^{2}$} & 1475 & 1416 & 1265 & 3468 & - & 464 & 524 \\
\hline & (1474) & (1416) & (1267) & (3515) & & (423) & (545) \\
\hline \multirow[t]{2}{*}{$\mathrm{Ni}-\mathrm{L}^{3}$} & 1473 & 1418 & 1252 & 3477 & 1637 & 471 & 522 \\
\hline & (1463) & (1401) & (1258) & (3542) & (1643) & (433) & (518) \\
\hline \multirow[t]{2}{*}{$\mathrm{Ni}-\mathrm{L}^{4}$} & 1480 & 1410 & 1263 & 3448 & 1631 & 465 & 523 \\
\hline & (1470) & (1397) & (1259) & $(3545)$ & (1634) & (431) & (531) \\
\hline \multirow[t]{2}{*}{ Ni-L ${ }^{5}$} & 1483 & 1418 & 1258 & 3467 & - & 464 & 536 \\
\hline & (1481) & (1409) & (1264) & (3539) & & (449) & (538) \\
\hline \multirow[t]{2}{*}{$\mathrm{Ni}-\mathrm{L}^{6}$} & 1475 & 1408 & 1271 & 3467 & - & 464 & 525 \\
\hline & (1470) & (1410) & (1285) & (3531) & & (450) & (543) \\
\hline
\end{tabular}


Table 3.The main absorbance bands (cm-1) of the ligands in UV-visible and their assignments.

\begin{tabular}{llll}
\hline Ligand & $\lambda \mathrm{nm}\left(\mathrm{cm}^{-1}\right)$ & $\varepsilon\left(\mathrm{mole}^{-1} . \mathrm{L} . \mathrm{cm}^{-1}\right)$ & Electronic transitions \\
\hline $\mathrm{L}^{1}$ & $273(36630)$ & 30300 & $\pi \rightarrow \pi^{*}$ \\
& $315(31055)$ & 14500 & $\mathrm{n} \rightarrow \pi^{*}$ \\
\hline $\mathrm{L}^{2}$ & $246(40650)$ & 14270 & $\pi \rightarrow \pi^{*}$ \\
& $317(31545)$ & 22900 & $\mathrm{n} \rightarrow \pi^{*}$ \\
\hline $\mathrm{L}^{3}$ & $250(40000)$ & 14890 & $\pi \rightarrow \pi^{*}$ \\
& $302(33557)$ & 18300 & $\pi \rightarrow \pi^{*}$ \\
\hline $\mathrm{L}^{4}$ & $244(40983)$ & 11330 & $\pi \rightarrow \pi^{*}$ \\
& $282(35971)$ & 28200 & $\mathrm{n} \rightarrow \pi^{*}$ \\
\hline $\mathrm{L}^{5}$ & $281(35587)$ & 34600 & $\pi \rightarrow \pi^{*}$ \\
& $316(31646)$ & 22100 & $\mathrm{n} \rightarrow \pi^{*}$ \\
\hline $\mathrm{L}^{6}$ & $275(36101)$ & 68800 & $\pi \rightarrow \pi^{*}$ \\
& $324(30864)$ & 16700 & $\mathrm{n} \rightarrow \pi^{*}$ \\
\hline
\end{tabular}


Table4.The main absorbance bands $\left(\mathrm{cm}^{-1}\right)$ of $\mathrm{Ni}$ (II) complexes in UV-visible and their assignments.

\begin{tabular}{|c|c|c|c|c|}
\hline Compounds & $\begin{array}{c}\text { Wavenumber } \\
\bar{v}\left(\mathrm{~cm}^{-1}\right)\end{array}$ & $\begin{array}{c}\text { Wavelength } \\
\lambda(\mathrm{nm})\end{array}$ & $\begin{array}{l}\text { Molar coefficient absorption } \\
\qquad\left(\text { mole }^{-1} . \mathrm{L} \mathrm{cm}^{-1}\right)\end{array}$ & Electronic transition \\
\hline \multirow{5}{*}{ Ni-L1 } & 37735 & 265 & 1009 & $\pi \rightarrow \pi^{*}$ \\
\hline & 31055 & 322 & 583 & $\mathrm{n} \rightarrow \pi^{*}$ \\
\hline & 25316 & 395 & 302 & ${ }^{3} \mathrm{~A}_{2 \mathrm{~g}}(\mathrm{~F}) \rightarrow{ }^{3} \mathrm{~T}_{2 \mathrm{~g}}(\mathrm{~F})$ \\
\hline & 15060 & 664 & 110 & ${ }^{3} \mathrm{~A}_{2 \mathrm{~g}}(\mathrm{~F}) \rightarrow{ }^{3} \mathrm{~T}_{1 \mathrm{~g}}(\mathrm{~F})$ \\
\hline & 10080 & 992 & 78 & ${ }^{3} \mathrm{~A}_{2 \mathrm{~g}}(\mathrm{~F}) \rightarrow{ }^{3} \mathrm{~T}_{2 \mathrm{~g}}(\mathrm{P})$ \\
\hline \multirow{5}{*}{ Ni-L2 } & 36630 & 273 & 833 & $\pi \rightarrow \pi^{*}$ \\
\hline & 30303 & 330 & 490 & $\mathrm{n} \rightarrow \pi^{*}$ \\
\hline & 25706 & 389 & 343 & ${ }^{3} \mathrm{~A}_{2 \mathrm{~g}}(\mathrm{~F}) \rightarrow{ }^{3} \mathrm{~T}_{2 \mathrm{~g}}(\mathrm{~F})$ \\
\hline & 14925 & 670 & 154 & ${ }^{3} \mathrm{~A}_{2 \mathrm{~g}}(\mathrm{~F}) \rightarrow{ }^{3} \mathrm{~T}_{1 \mathrm{~g}}(\mathrm{~F})$ \\
\hline & 10152 & 985 & 112 & ${ }^{3} \mathrm{~A}_{2 \mathrm{~g}}(\mathrm{~F}) \rightarrow{ }^{3} \mathrm{~T}_{2 \mathrm{~g}}(\mathrm{P})$ \\
\hline \multirow{5}{*}{ Ni-L3 } & 36496 & 274 & 718 & $\pi \rightarrow \pi^{*}$ \\
\hline & 30864 & 324 & 453 & $\mathrm{n} \rightarrow \pi^{*}$ \\
\hline & 25575 & 391 & 287 & ${ }^{3} \mathrm{~A}_{2 \mathrm{~g}}(\mathrm{~F}) \rightarrow{ }^{3} \mathrm{~T}_{2 \mathrm{~g}}(\mathrm{~F})$ \\
\hline & 15015 & 666 & 145 & ${ }^{3} \mathrm{~A}_{2 \mathrm{~g}}(\mathrm{~F}) \rightarrow{ }^{3} \mathrm{~T}_{1 \mathrm{~g}}(\mathrm{~F})$ \\
\hline & 10141 & 986 & 111 & ${ }^{3} \mathrm{~A}_{2 \mathrm{~g}}(\mathrm{~F}) \rightarrow{ }^{3} \mathrm{~T}_{2 \mathrm{~g}}(\mathrm{P})$ \\
\hline \multirow{5}{*}{ Ni-L4 } & 40816 & 275 & 938 & $\pi \rightarrow \pi^{*}$ \\
\hline & 31446 & 318 & 736 & $\mathrm{n} \rightarrow \pi^{*}$ \\
\hline & 25641 & 390 & 402 & ${ }^{3} \mathrm{~A}_{2 \mathrm{~g}}(\mathrm{~F}) \rightarrow{ }^{3} \mathrm{~T}_{2 \mathrm{~g}}(\mathrm{~F})$ \\
\hline & 14771 & 677 & 160 & ${ }^{3} \mathrm{~A}_{2 \mathrm{~g}}(\mathrm{~F}) \rightarrow{ }^{3} \mathrm{~T}_{1 \mathrm{~g}}(\mathrm{~F})$ \\
\hline & 10141 & 986 & 101 & ${ }^{3} \mathrm{~A}_{2 \mathrm{~g}}(\mathrm{~F}) \rightarrow{ }^{3} \mathrm{~T}_{2 \mathrm{~g}}(\mathrm{P})$ \\
\hline \multirow{5}{*}{ Ni-L5 } & 37735 & 265 & 1273 & $\pi \rightarrow \pi^{*}$ \\
\hline & 30864 & 324 & 547 & $\mathrm{n} \rightarrow \pi^{*}$ \\
\hline & 25316 & 395 & 304 & ${ }^{3} \mathrm{~A}_{2 \mathrm{~g}}(\mathrm{~F}) \rightarrow{ }^{3} \mathrm{~T}_{2 \mathrm{~g}}(\mathrm{~F})$ \\
\hline & 15015 & 666 & 104 & ${ }^{3} \mathrm{~A}_{2 \mathrm{~g}}(\mathrm{~F}) \rightarrow{ }^{3} \mathrm{~T}_{1 \mathrm{~g}}(\mathrm{~F})$ \\
\hline & 10070 & 993 & 70 & ${ }^{3} \mathrm{~A}_{2 \mathrm{~g}}(\mathrm{~F}) \rightarrow{ }^{3} \mathrm{~T}_{2 \mathrm{~g}}(\mathrm{P})$ \\
\hline \multirow{5}{*}{ Ni-L6 } & 37735 & 265 & 1000 & $\pi \rightarrow \pi^{*}$ \\
\hline & 30769 & 325 & 483 & $\mathrm{n} \rightarrow \pi^{*}$ \\
\hline & 25316 & 395 & 321 & ${ }^{3} \mathrm{~A}_{2 \mathrm{~g}}(\mathrm{~F}) \rightarrow{ }^{3} \mathrm{~T}_{2 \mathrm{~g}}(\mathrm{~F})$ \\
\hline & 14992 & 667 & 139 & ${ }^{3} \mathrm{~A}_{2 \mathrm{~g}}(\mathrm{~F}) \rightarrow{ }^{3} \mathrm{~T}_{1 \mathrm{~g}}(\mathrm{~F})$ \\
\hline & 10091 & 991 & 97 & ${ }^{3} \mathrm{~A}_{2 \mathrm{~g}}(\mathrm{~F}) \rightarrow{ }^{3} \mathrm{~T}_{2 \mathrm{~g}}(\mathrm{P})$ \\
\hline
\end{tabular}


Table 5.Thermogravimetric results of the complexes.

\begin{tabular}{|c|c|c|c|c|c|}
\hline \multirow[t]{2}{*}{ Complexes } & \multirow[t]{2}{*}{ Steps } & \multirow[t]{2}{*}{ Temperature $\left({ }^{\circ} \mathrm{C}\right)$} & \multirow{2}{*}{$\begin{array}{l}\text { Leaving } \\
\text { group }\end{array}$} & \multicolumn{2}{|c|}{ Mass Loss $\%$} \\
\hline & & & & Expt & Calc \\
\hline & 1 & $50-160$ & $\mathrm{H}_{2} \mathrm{O}$ & 8.1 & 7.23 \\
\hline & $2+3$ & $160-356+356-565$ & $\mathrm{~L}_{2}$ & $44.1+25.2$ & $45.84+20.7+5.63$ \\
\hline \multirow[t]{4}{*}[\mathrm{Ni}\mathrm{L}_{2}{}_{2}\mathrm{Cl}_{2}(\mathrm{H}_{2}\mathrm{O})_{2}]{$.2 \mathrm{H} 2 \mathrm{O}$} & 4 & $565-767$ & $\mathrm{Cl}_{2}$ & 7.8 & 7.127 \\
\hline & & & $\mathrm{NiO}$ & 8.5 & 7.49 \\
\hline & 1 & $50-173$ & $\mathrm{H}_{2} \mathrm{O}$ & 8.9 & 8.27 \\
\hline & $2+3$ & $173-560$ & $\mathrm{~L}_{2}$ & $40.1+28.3$ & $41.82+23.66+6.43$ \\
\hline \multirow[t]{4}{*}[\mathrm{Ni}\mathrm{L}_{2}{}_{2}\mathrm{Cl}_{2}(\mathrm{H}_{2}\mathrm{O})_{2}]{$.2 \mathrm{H} 2 \mathrm{O}$} & 4 & $560-850$ & $\mathrm{Cl}_{2}$ & 7.9 & 8.145 \\
\hline & & & $\mathrm{NiO}$ & 11.3 & 10.515 \\
\hline & 1 & $50-190$ & $\mathrm{H}_{2} \mathrm{O}$ & 8.4 & 7.64 \\
\hline & $2+3$ & $190-460$ & $\mathrm{~L}_{2}$ & $56.7+16.6$ & $57.53+11.46+5.94$ \\
\hline \multirow[t]{4}{*}[\mathrm{Ni}\mathrm{L}^{3}{}_{2}\mathrm{Cl}_{2}(\mathrm{H}_{2}\mathrm{O})_{2}]{$.2 \mathrm{H} 2 \mathrm{O}$} & 4 & $460-870$ & $\mathrm{Cl}_{2}$ & 7.3 & 7.53 \\
\hline & & & $\mathrm{NiO}$ & 8.6 & 8.62 \\
\hline & 1 & $50-176$ & $\mathrm{H}_{2} \mathrm{O}$ & 8.7 & 8.29 \\
\hline & $2+3$ & $176-334+334-444$ & $\mathrm{~L}_{2}$ & $52.3+17.3$ & $51.34+12.16+6.30$ \\
\hline \multirow[t]{4}{*}[\mathrm{Ni}\mathrm{L}_{2}{}_{2}\mathrm{Cl}_{2}(\mathrm{H}_{2}\mathrm{O})_{2}]{$.2 \mathrm{H} 2 \mathrm{O}$} & 4 & $444-900$ & $\mathrm{Cl}_{2}$ & 7.9 & 7.98 \\
\hline & & & $\mathrm{NiO}$ & 8.5 & 8.608 \\
\hline & 1 & $50-201$ & $\mathrm{H}_{2} \mathrm{O}$ & 10.7 & 9.03 \\
\hline & $2+3$ & $201-430+430-557$ & $\mathrm{~L}_{2}$ & $57.9+13.4$ & $57.21+6.77+7.02$ \\
\hline \multirow[t]{3}{*}[\mathrm{Ni}\mathrm{L}_{2}^{5}\mathrm{Cl}_{2}(\mathrm{H}_{2}\mathrm{O})_{2}]{$.2 \mathrm{H} 2 \mathrm{O}$} & 4 & $557-828$ & $\mathrm{Cl}_{2}$ & 7.2 & 8.89 \\
\hline & & & $\mathrm{NiO}$ & 10.7 & 9.369 \\
\hline & 1 & $50-179$ & $\mathrm{H}_{2} \mathrm{O}$ & 10.2 & 9.62 \\
\hline \multirow[t]{3}{*}[\mathrm{Ni}\mathrm{L}^{6}{}_{2}\mathrm{Cl}_{2}(\mathrm{H}_{2}\mathrm{O})_{2}]{$.2 \mathrm{H} 2 \mathrm{O}$} & 2 & $179-548$ & $\mathrm{~L}_{2}$ & 63.3 & $48+7.214+7.48$ \\
\hline & 3 & $548-815$ & $\mathrm{Cl}_{2}$ & 8.6 & 9.47 \\
\hline & & & $\mathrm{NiO}$ & 9.3 & 9.95 \\
\hline
\end{tabular}


Table 6.Calculated structural parameters and NBO charge of the ligands and their complexes.

\begin{tabular}{|c|c|c|c|c|c|c|}
\hline Parameters & $\mathrm{L}^{1}$ & $\mathrm{~L}^{2}$ & $\mathrm{~L}^{3}$ & $\mathrm{~L}^{4}$ & $\mathrm{~L}^{5}$ & $\mathrm{~L}^{6}$ \\
\hline \multicolumn{7}{|l|}{ Bond lengths $(\AA)$} \\
\hline $\mathrm{N} 3-\mathrm{N} 2$ & 1.332 & 1.330 & 1.316 & 1.314 & 1.332 & 1.332 \\
\hline N3-N4 & 1.395 & 1.396 & 1.408 & 1.409 & 1.395 & 1.396 \\
\hline \multicolumn{7}{|l|}{$\begin{array}{l}\text { Dihedral angles } \\
\left({ }^{\circ}\right)\end{array}$} \\
\hline N2-N3-N4-C1 & 0.2 & 0.2 & 0.5 & 0.2 & 0.4 & 0.3 \\
\hline \multicolumn{7}{|l|}{ NBO Charge (e) } \\
\hline Parameters & $\mathrm{Ni}-\mathrm{L}^{1}$ & $\mathrm{Ni}-\mathrm{L}^{2}$ & $\mathrm{Ni}-\mathrm{L}^{3}$ & $\mathrm{Ni}-\mathrm{L}^{4}$ & $\mathrm{Ni}-\mathrm{L}^{5}$ & $\mathrm{Ni}-\mathrm{L}^{6}$ \\
\hline \multicolumn{7}{|l|}{ Bond length $(\AA)$} \\
\hline Ni-N3 & 2.093 & 2.121 & 2.095 & 2.099 & 2.094 & 2.099 \\
\hline Ni-N48 & 2.091 & 2.095 & 2.102 & 2.099 & 2.109 & 2.116 \\
\hline $\mathrm{Ni}-\mathrm{Cl} 192$ & 2.423 & 2.439 & 2.405 & 2.407 & 2.407 & 2.419 \\
\hline $\mathrm{Ni}-\mathrm{Cl} 193$ & 2.523 & 2.500 & 2.497 & 2.496 & 2.518 & 2.508 \\
\hline $\mathrm{Ni}-\mathrm{O} 94$ & 2.102 & 2.093 & 2.099 & 2.098 & 2.098 & 2.094 \\
\hline Ni-O96 & 2.108 & 2.096 & 2.099 & 2.101 & 2.101 & 2.102 \\
\hline N3-N2 & 1.321 & 1.320 & 1.308 & 1.306 & 1.321 & 1.321 \\
\hline N48-N47 & 1.321 & 1.320 & 1.308 & 1.307 & 1.322 & 1.322 \\
\hline N3-N4 & 1.389 & 1.390 & 1.398 & 1.398 & 1.386 & 1.388 \\
\hline N48-N49 & 1.388 & 1.389 & 1.399 & 1.399 & 1.388 & 1.390 \\
\hline \multicolumn{7}{|l|}{ Bond angles $\left({ }^{\circ}\right)$} \\
\hline N3-Ni-N48 & 175.6 & 172.7 & 174.2 & 173.4 & 176.7 & 174.3 \\
\hline C192-Ni-C193 & 179.0 & 178.5 & 177.9 & 179.4 & 178.2 & 179.7 \\
\hline O94-Ni-O96 & 163.9 & 165.7 & 165.3 & 165.4 & 165.1 & 165.1 \\
\hline N3-Ni-Cl92 & 86.0 & 85.2 & 86.9 & 87.1 & 89.3 & 88.4 \\
\hline N48-Ni-C193 & 89.5 & 91.3 & 94.6 & 93.2 & 94.1 & 94.1 \\
\hline N3-Ni-C193 & 94.7 & 96.0 & 91.2 & 93.4 & 89.1 & 91.6 \\
\hline N48-Ni-C192 & 89.7 & 87.5 & 87.3 & 86.3 & 87.5 & 85.9 \\
\hline O94-Ni-N3 & 85.8 & 94.9 & 94.7 & 94.8 & 94.5 & 95.7 \\
\hline O96-Ni-N48 & 85.4 & 95.9 & 94.3 & 94.8 & 94.6 & 94.5 \\
\hline O94-Ni-C192 & 98.7 & 96.3 & 98.3 & 97.0 & 97.9 & 96.9 \\
\hline O96-Ni-C193 & 81.9 & 82.9 & 82.4 & 82.6 & 82.2 & 82.3 \\
\hline \multicolumn{7}{|l|}{ Dihedral angles $\left({ }^{\circ}\right)$} \\
\hline N3-Ni-N48-N47 & 78.6 & 85.6 & 83.4 & 78.7 & 91.8 & 74.4 \\
\hline N48-Ni-N3-N2 & 89.9 & 75.8 & 87.6 & 90.6 & 83.2 & 92.5 \\
\hline N2-N3-N4-Ni & 160.8 & 154.0 & 172.2 & 169.0 & 177.4 & 172.2 \\
\hline N47-N48-N49-Ni & 175.5 & 170.8 & 168.2 & 163.7 & 165.3 & 160.2 \\
\hline N2-N3-N4-C1 & 0.7 & 1.3 & 0.7 & 0.8 & 0.2 & 0.3 \\
\hline N47-N48-N49- & 0.6 & 0.7 & 0.3 & 0.6 & 0.9 & 1.5 \\
\hline \multicolumn{7}{|l|}{$\mathrm{C} 46$} \\
\hline \multicolumn{7}{|l|}{ NBO Charges (e) } \\
\hline $\mathrm{Ni}$ & 0.717 & 0.718 & 0.723 & 0.725 & 0.704 & 0.707 \\
\hline N3 & -0.109 & -0.108 & -0.081 & -0.079 & -0.103 & -0.105 \\
\hline N48 & -0.104 & -0.102 & -0.080 & -0.077 & -0.100 & -0.101 \\
\hline $\mathrm{C} 192$ & -0.593 & -0.605 & -0.570 & -0.575 & -0.581 & -0.593 \\
\hline $\mathrm{Cl} 93$ & -0.631 & -0.625 & -0.619 & -0.619 & -0.632 & -0.629 \\
\hline O94 & -0.944 & -0.944 & -0.945 & -0.945 & -0.943 & -0.593 \\
\hline O96 & -0.945 & -0.947 & -0.945 & -0.945 & -0.944 & -0.629 \\
\hline
\end{tabular}


Table 7.Energy properties of the ligands and their complexes.

\begin{tabular}{lllllll}
\hline Parameters & $\mathrm{L}^{1}$ & $\mathrm{~L}^{2}$ & $\mathrm{~L}^{3}$ & $\mathrm{~L}^{4}$ & $\mathrm{~L}^{5}$ & $\mathrm{~L}^{6}$ \\
\hline HOMO $(\mathrm{eV})$ & -6.588 & -5.939 & -6.511 & -5.810 & -6.637 & -5.986 \\
LUMO $(\mathrm{eV})$ & -1.782 & -1.458 & -2.563 & -2.490 & -1.844 & -1.510 \\
Gap $(\mathrm{eV})$ & 4.806 & 4.481 & 3.948 & 3.320 & 4.793 & 4.476 \\
\hline Parameters & $\mathrm{Ni}-\mathrm{L}^{1}$ & $\mathrm{Ni}-\mathrm{L}^{2}$ & $\mathrm{Ni}-\mathrm{L}^{3}$ & $\mathrm{Ni}-\mathrm{L}^{4}$ & $\mathrm{Ni}-\mathrm{L}^{5}$ & $\mathrm{Ni}-\mathrm{L}^{6}$ \\
\hline HOMO $(\mathrm{eV})$ & -5.462 & -5.324 & -5.279 & -5.128 & -5.719 & -5.539 \\
LUMO $(\mathrm{eV})$ & -1.664 & -1.942 & -2.807 & -2.702 & -1.589 & -1.786 \\
$\Delta \mathrm{E}(\mathrm{eV})$ & 3.798 & 3.382 & 2.472 & 2.426 & 4.130 & 3.753 \\
\hline
\end{tabular}

Table8.Binding energies of the complexes obtained at DFT level.

\begin{tabular}{cc}
\hline Complexes & $\mathrm{E}_{\text {binding }}(\mathrm{Kcal} / \mathrm{mol})$ \\
\hline Ni-L & -120.084 \\
Ni-L & -120.023 \\
Ni-L & -117.577 \\
Ni-L & -117.540 \\
Ni-L & -123.466 \\
Ni-L & -122.873 \\
\hline
\end{tabular}


Table 9.Redox potentials of the ligands.

\begin{tabular}{llll|lll}
\hline Compounds & \multicolumn{3}{l}{ Reduction } & \multicolumn{3}{l}{ Oxidation } \\
\cline { 2 - 7 } & $\mathrm{E}_{\mathrm{Pc}}(\mathrm{V})$ & $\mathrm{E}_{\mathrm{Pa}}(\mathrm{V})$ & $\Delta \mathrm{E}(\mathrm{V})$ & $\mathrm{E}_{\mathrm{Pa}}(\mathrm{V})$ & $\mathrm{E}_{\mathrm{Pc}}(\mathrm{V})$ & $\Delta \mathrm{E}(\mathrm{V})$ \\
\hline $\mathrm{L}^{1}$ & -0.92 & -0.46 & 0.46 & +0.88 & +0.18 & 0.69 \\
& -0.32 & -0.12 & 0.20 & & & \\
\hline $\mathrm{L}^{2}$ & -0.91 & -0.48 & 0.41 & +0.51 & +0.13 & 0.38 \\
& -0.31 & -0.12 & 0.18 & & & \\
\hline $\mathrm{L}^{3}$ & -0.88 & -0.44 & 0.44 & +0.97 & +0.15 & 0.82 \\
& -0.31 & -0.11 & 0.2 & & & \\
\hline $\mathrm{L}^{4}$ & -0.87 & -0.50 & 0.37 & +0.56 & +0.14 & 0.42 \\
& -0.28 & -0.12 & 0.16 & & & \\
\hline $\mathrm{L}^{5}$ & -0.98 & -0.51 & 0.47 & +0.74 & +0.14 & 0.59 \\
& -0.35 & -0.09 & 0.25 & & & \\
\hline $\mathrm{L}^{6}$ & -0.93 & -0.53 & 0.39 & +0.46 & +0.18 & 0.28 \\
& -0.33 & -0.15 & 0.18 & & & \\
\hline
\end{tabular}


Table 10.Redox potentials of the nickel complexes.

\begin{tabular}{|c|c|c|c|c|c|c|}
\hline \multirow[t]{2}{*}{ Compounds } & \multicolumn{3}{|c|}{ Reduction } & \multicolumn{3}{|c|}{ Oxidation } \\
\hline & $\mathrm{E}_{\mathrm{Pc}}(\mathrm{V})$ & $\mathrm{E}_{\mathrm{Pa}}(\mathrm{V})$ & $\Delta \mathrm{E}(\mathrm{V})$ & $\mathrm{E}_{\mathrm{Pa}}(\mathrm{V})$ & $\mathrm{E}_{\mathrm{Pc}}(\mathrm{V})$ & $\Delta \mathrm{E}(\mathrm{V})$ \\
\hline \multirow[t]{3}{*}{$\mathrm{Ni}-\mathrm{L}^{1}$} & -1.45 & -0.75 & 0.71 & \multirow{3}{*}{+0.87} & \multirow{3}{*}{+0.16} & \multirow{3}{*}{0.71} \\
\hline & -0.89 & -0.51 & 0.38 & & & \\
\hline & -0.31 & -0.14 & 0.17 & & & \\
\hline \multirow[t]{3}{*}{$\mathrm{Ni}-\mathrm{L}^{2}$} & -1.44 & -0.73 & 0.70 & \multirow{3}{*}{+0.59} & \multirow{3}{*}{+0.12} & \\
\hline & -0.88 & -0.51 & 0.36 & & & 0.47 \\
\hline & -0.28 & -0.16 & 0.12 & & & \\
\hline \multirow[t]{3}{*}{$\mathrm{Ni}-\mathrm{L}^{3}$} & -1.43 & -0.73 & 0.71 & \multirow{3}{*}{+0.93} & \multirow{3}{*}{+0.26} & \multirow{3}{*}{0.67} \\
\hline & -0.86 & -0.53 & 0.33 & & & \\
\hline & -0.31 & -0.13 & 0.16 & & & \\
\hline \multirow[t]{3}{*}{$\mathrm{Ni}-\mathrm{L}^{4}$} & -1.42 & -0.72 & 0.71 & \multirow{3}{*}{+0.54} & \multirow{3}{*}{+0.15} & \multirow{3}{*}{0.39} \\
\hline & -0.85 & -0.53 & 0.32 & & & \\
\hline & -0.27 & -0.15 & 0.12 & & & \\
\hline \multirow[t]{3}{*}{$\mathrm{Ni}-\mathrm{L}^{5}$} & -1.48 & -0.79 & 0.69 & \multirow{3}{*}{+0.69} & \multirow{3}{*}{+0.11} & \multirow{3}{*}{0.59} \\
\hline & -0.94 & -0.52 & 0.41 & & & \\
\hline & -0.34 & -0.09 & 0.24 & & & \\
\hline \multirow[t]{3}{*}{$\mathrm{Ni}-\mathrm{L}^{6}$} & -1.46 & -0.76 & 0.71 & \multirow{3}{*}{+0.44} & \multirow{3}{*}{+0.15} & \multirow{3}{*}{0.29} \\
\hline & -0.91 & -0.54 & 0.36 & & & \\
\hline & -0.32 & -0.11 & 0.21 & & & \\
\hline
\end{tabular}


Table 11.Antioxidant activity of the ligands and their complexes.

\begin{tabular}{lll}
\hline Compounds & Ascorbic acid Eq $(\mu \mathrm{M})$ & AA $\%$ \\
\hline $\mathrm{L}^{1}$ & 27.9 & 22.74 \\
\hline $\mathrm{L}^{2}$ & 30.1 & 25.91 \\
\hline $\mathrm{L}^{3}$ & 31.3 & 27.79 \\
\hline $\mathrm{L}^{4}$ & 31.5 & 28.20 \\
\hline $\mathrm{L}^{5}$ & 26.7 & 20.76 \\
\hline $\mathrm{L}^{6}$ & 28.7 & 23.84 \\
\hline $\mathrm{Ni}-\mathrm{L}^{1}$ & 30.8 & 27.06 \\
\hline $\mathrm{Ni}-\mathrm{L}^{2}$ & 39.8 & 40.76 \\
\hline $\mathrm{Ni}-\mathrm{L}^{3}$ & 33.5 & 31.14 \\
\hline Ni-L ${ }^{4}$ & 41.2 & 42.28 \\
\hline Ni-L & 30.2 & 26.14 \\
\hline Ni-L & 34.9 & 33.19 \\
\hline Chlorogenic acid $^{5}$ & 10.6 & 29.78 \\
\hline
\end{tabular}

\section{AUTHORS STATEMENT}

Manuscript title: Impact of the functionalized tetrazole ring on the electrochemical behavior and biological activities of novel nickel (II) complexes with a series of tetrazole derivatives Corresponding author's full name: Yacine Allab

\begin{tabular}{cl}
\hline No. & \multicolumn{1}{c}{ Author's full name } \\
\hline 1. & Yacine Allab \\
\hline 2. & Sabah Chikhi \\
\hline 3. & Sihem Zaater \\
\hline 4. & Meziane Brahimi \\
\hline 5. & Safia Djebbar \\
\hline
\end{tabular}

\section{AUTHORSHIP STATEMENT:}

\begin{tabular}{l|l}
\hline Component of the research & \multicolumn{1}{c}{ Author's number } \\
\hline Conceptualization & 1 and 5 \\
\hline Software & 3 and 4 \\
\hline
\end{tabular}




\begin{tabular}{l|l}
\hline Validation & 1 \\
\hline Formal analysis & 1,2 and 5 \\
\hline Investigation & 1 \\
\hline Resources & $1,2,3,4$ and 5 \\
\hline Data Curation & 1 \\
\hline Writing - Original Draft & 1 and 5 \\
\hline Writing - Review \& Editing & 1,3 and 5 \\
\hline Visualization & 1 \\
\hline Supervision & 5 \\
\hline Project administration & 1 and 5 \\
\hline &
\end{tabular}

